\title{
13. LATE MIOCENE TO HOLOCENE GLACIAL HISTORY OF EAST ANTARCTICA REVEALED BY SEDIMENTS FROM SITES 745 AND $746^{1}$
}

\author{
Werner U. Ehrmann, ${ }^{2}$ Hannes Grobe, ${ }^{2}$ and Dieter K. Fütterer ${ }^{2}$
}

\begin{abstract}
The sediments recovered at ODP Sites 745 and 746 in the Australian-Antarctic Basin are characterized by cyclic facies changes between clayey diatom oozes and diatomaceous clays ranging in age from late Miocene (about $10 \mathrm{Ma}$ ) to Quaternary.

The gravel and terrigenous sand content of the sediments is used as an indicator of the intensity of ice rafting through time. Maxima are recorded at 8.7-7.9, 6.6-6.0, 5.0-4.4, and 4.0-3.2 Ma. The maxima in more recent times are much less pronounced and occur at 2.4-1.6 and 1.4-1.0 Ma. All sand- and gravel-sized terrigenous sediment particles are of gneissic or granitic origin and originated from the East Antarctic continent. The maxima of ice rafting recorded at Sites 745 and 746 do not appear to represent local phenomena. Rather they document major advances and decays of the Antarctic ice shelves and glaciers and therefore represent events of great importance for the reconstruction of the paleoceanography of the Southern Ocean and the glacial history of Antarctica. In general, ice rafting was pronounced in the late Miocene and early Pliocene epochs, which are characterized by repeated ice advances and retreats. Ice rafting was less intensive during the late Pliocene to Quaternary time period, when ice shelves remained relative stable.

The clay minerals indicate the fluctuating influence of different source areas on the delivery of fine-grained terrigenous sediment components. Part of this material may have been delivered from the Permian Amery Formation or from equivalents of this formation.
\end{abstract}

\section{INTRODUCTION}

One of the major objectives of Ocean Drilling Program (ODP) Leg 119 was to study the long-term glacial history of East Antarctica. While the drill sites in Prydz Bay allow only a rough reconstruction of the glacial history since the early Oligocene or possibly late Eocene time (Hambrey et al., 1989; this volume), some elements of ice sheet development and its Neogene growth remain obscure because of the poor recovery, major hiatuses in the record, and the problem of dating. The Leg 119 (and 120) sites on the Kerguelen Plateau also document, by their record of ice rafting and clay mineralogy, the glacial history to some degree (Ehrmann, this volume; Schlich, Wise, et al., 1989). However, those sites also show few details because of low sedimentation rates, great distance from the Antarctic continent, and dilution of indicative sediment components by other particles.

ODP Leg 119 Sites $745\left(59^{\circ} 35.71^{\prime} \mathrm{S}, 85^{\circ} 51.60^{\prime} \mathrm{E}\right)$ and 746 $\left(59^{\circ} 32.82^{\prime} \mathrm{S}, 85^{\circ} 51.78^{\prime} \mathrm{E}\right)$, which were drilled in the AustralianAntarctic Basin (Fig. 1) in water depths of 4082 and 4059 m, respectively, may provide important information concerning the late Neogene and Quaternary glacial history of East Antarctica, because of relatively high sedimentation rates and a good stratigraphic control (Barron, Larsen, et al., 1989).

Drilling at Site 745 with the advanced piston corer (APC) recovered $215 \mathrm{~m}$ of sediments that range stratigraphically from the uppermost Miocene to the Quaternary, thus spanning the last $\sim 6 \mathrm{Ma}$ (Fig. 2). Site 746, which was drilled with the APC and extended core barrel only $5.5 \mathrm{~km}$ north of Site 745 , was continuously cored from 165 to $281 \mathrm{~m}$ below seafloor (mbsf), which completed the stratigraphic record without any significant gap down to the lower upper Miocene (about $10 \mathrm{Ma}$; Fig. 3 ). The drilling technique and the nature of the sediments were

\footnotetext{
${ }^{1}$ Barron, J., Larsen, B., et al., 1991. Proc. ODP, Sci. Results, 119: College Station, TX (Ocean Drilling Program).

2 Alfred Wegener Institute for Polar and Marine Research, Columbusstraße, D 2850 Bremerhaven, FRG.
}

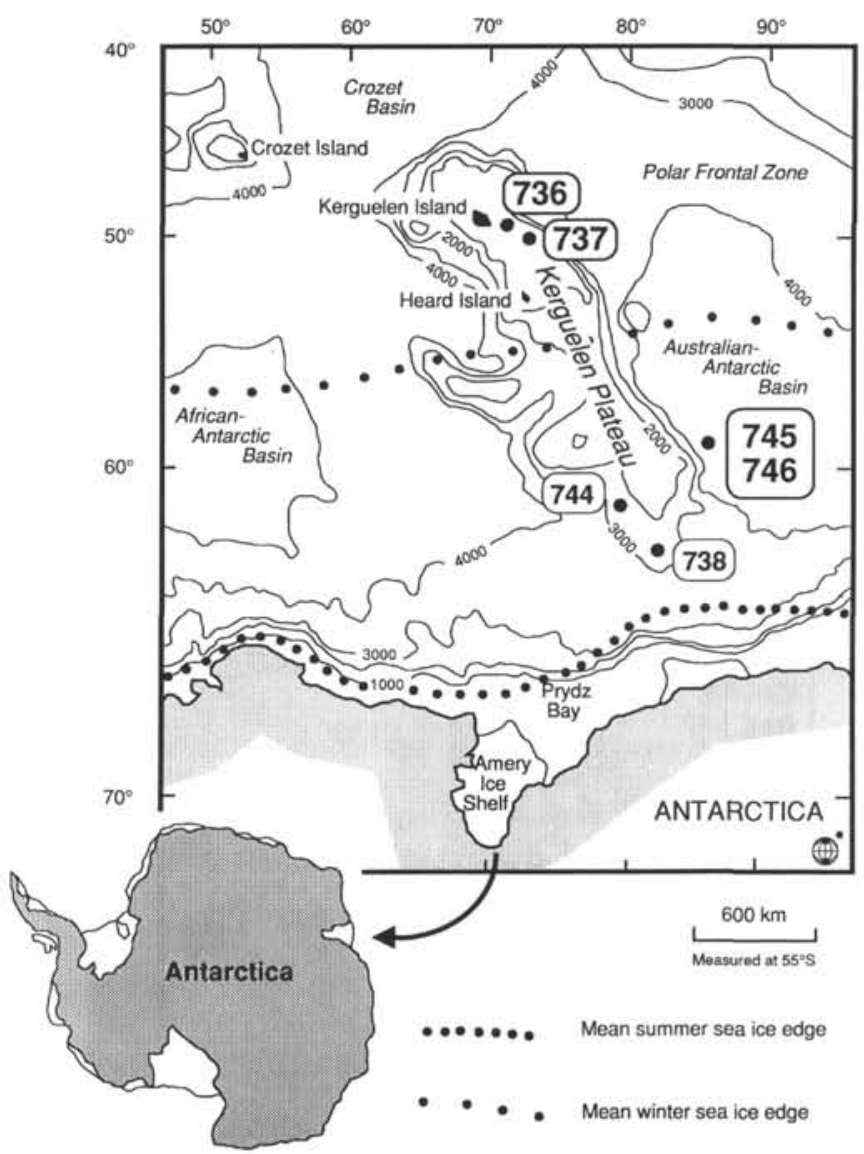

Figure 1. Location map of ODP Leg 119 Sites 745 and 746. Bathymetry (in meters) is from GEBCO (Hayes and Vogel, 1981; Fisher et al., 1982). The position of the Polar Front is according to Whitworth (1988), the mean sea ice coverage in summer and winter according to Dietrich and Ulrich (1968). 
such that the recovery rate was almost $100 \%$ at Site 745 and $75 \%$ at Site 746 . Biostratigraphy based on diatoms (Baldauf and Barron, this volume) and an excellent magnetostratigraphic record (H. Sakai, pers. comm., 1989) give no indication of significant hiatuses. Sedimentation rates ranged mainly from 25 to $50 \mathrm{~m} / \mathrm{Ma}$.

In the typical distal glaciomarine sediments of Sites 745 and 746 , two different facies have been defined, which alternate cyclically throughout the sedimentary sequence (Ehrmann and Grobe, this volume). Facies A corresponds to an interglacial facies and is dominated by a high content of siliceous microfossils, consisting mainly of diatoms and radiolarians, a relatively low terrigenous sediment component, an ice-rafted component, low concentrations of clay and fine silt particles, and a relatively high smectite content. Facies B was deposited under conditions with extended ice shelves. It is dominated by a large amount of terrigenous material and a smaller opaline component. Icerafted debris is also present, and the microfossils commonly are reworked and broken. The clay mineral assemblage shows higher proportions of glacially derived clay minerals. Calcareous sediment components are only minor constituents in both facies. The lithology is essentially the same throughout the two holes. A minor lithologic unit of 60 -cm-thick diatomaceous nannofossil ooze occurs at 246.7 mbsf.

\section{METHODS}

One hundred and fifty-four samples from Site 745 and 56 samples from Site 746 were analyzed. Samples were taken in intervals of approximately $1.5 \mathrm{~m}$ irrespective of the sedimentary facies. The sample size was $5-10 \mathrm{~cm}^{3}$. Depth information given in this paper is corrected for core recoveries $>100 \%$, which resulted from pressure release as the cores obtained from several thousand meters of water depth were brought to the surface.

Carbonate and organic carbon were measured using a Coulomat. The grain sizes were determined by washing the samples through $2-\mathrm{mm}$ and $63-\mu \mathrm{m}$ sieves and subsequent separation of the clay fraction $(<2 \mu \mathrm{m})$ from the $<63-\mu \mathrm{m}$ fraction by decantation. In order to remove the biogenic opaline components from the terrigenous sedimentary particles, a density separation was performed on the sand and silt fractions. Amorphous silica was removed from the $<2-\mu \mathrm{m}$ fraction by leaching.

The clay mineral composition was analyzed by X-ray diffraction (XRD) of the opal-free and carbonate-free $<2-\mu \mathrm{m}$ fraction. In our semiquantitative evaluations of the clay mineral assemblages, we used empirically estimated correction factors on integrated basal peak areas of the individual clay mineral reflections from glycolated samples (Biscaye, 1964, 1965; Lange, 1982).

Quartz concentrations were calculated from XRD analyses using the internal standard method. Quartz/feldspar ratios are based on their peak area ratios. The analytical methods are described in more detail in Ehrmann and Grobe (this volume).

\section{SEDIMENTARY RECORD}

The sedimentary sequence at Sites 745 and 746 is characterized by cyclic facies changes. While the glacial-interglacial periods produce marked changes in the sediment composition, these can be regarded as "noise" in relation to the long-term trends (Robin, 1988). In order to deduce the late Neogene and Quaternary glacial history, the description and interpretation of sediment parameters therefore cannot refer to individual samples, but rather must rely on generalized patterns (Figs. 2 through 8 ).

Using information from the shipboard visual core descriptions, which were partly revised and completed later by evaluating color core photographs, 167 facies B intervals were identified in the sedimentary record of Sites 745 and 746 (Figs. 2 and 3 and Appendix Table 1). This number, however, is only approx- imate because identification of these intervals depended on the recovery and on the amount of drilling and cutting disturbance. It also depended on light and moisture conditions. Further difficulties arose where gradational boundaries were encountered and where the difference in clay content between the two facies is low, especially in large sections at Site 746.

The facies B intervals are normally 0.1 to $1 \mathrm{~m}$ thick (Appendix Table 1). Intervals of relatively low frequency and thickness of facies B occur in the upper $96 \mathrm{~m}$ at Site 745 . In the deeper part of this site and at Site 746, the frequency and thicknesses are greater. Maximum concentrations occur at Site 745 at 96-135 mbsf and at Site 746 at 171-187 and 214-235 mbsf. In the deeper part of the latter site, recovery is too poor to record cycles accurately (Fig. 3). These patterns can be correlated only roughly with the distribution pattern of clay concentration (Figs. 4 through 7) because samples were taken at constant intervals and not according to the sedimentary cycles. Samples taken at a closer spacing, however, show a strong correlation between the distribution of facies B intervals and the percentages of clay in the related samples (Ehrmann and Grobe, this volume).

\section{Bulk-Sediment Composition}

The concentration of opal is relatively constant throughout Site 746 and in the lower part of Site 745 (Figs. 2 and 3 and Appendix Table 2). Concentrations average about $40 \%$. At 180 mbsf the values begin to undulate and reach minima of some $20 \%$ between 120 and 100 mbsf and some $30 \%$ between 55 and 30 mbsf. Maxima of about $50 \%-55 \%$ occur at $85-65$ and $20-0$ mbsf. The concentration of terrigenous sediment components shows an inverse correlation pattern.

The concentration fluctuations of opaline and terrigenous components according to the cyclic sedimentation are of relatively low amplitudes at Site 746 and in the lower part of Site 745. At 120 mbsf at Site 745 the differences between facies A and $\mathrm{B}$ become more pronounced, and maximum amplitudes occur at 100-25 mbsf.

The highest carbonate concentrations (Figs. 2 and 3 and Appendix Table 2) are found from 240 to 260 mbsf at Site 746 and reach a peak within a 60 -cm-thick nannofossil ooze unit. A sample from the base of this unit had $27 \%$ carbonate, and shipboard smear slide analyses indicated $65 \%$ nannofossils (Barron, Larsen, et al., 1989). Otherwise, the carbonate concentrations are relatively constant and low. They are normally about $0.4 \%$ at Site 746 and $0.3 \%$ at Site 745 .

The organic carbon content is very low and fluctuates between $0.1 \%$ and $0.3 \%$ (Figs. 2 and 3 and Appendix Table 2). At Site 746 values tend to decrease slightly upcore, to $190 \mathrm{mbsf}$, whence there is a shift to increasing values. At Site 745 the concentrations of organic carbon are constant in the lowermost 40 $\mathrm{m}$. They decrease there to a broad and weak minimum at about $140 \mathrm{mbsf}$, before a medium level is reached between 110 and 50 mbsf. In approximately the uppermost $30 \mathrm{~m}$, the organic carbon values again are slightly higher.

The quartz concentrations fluctuate relatively strongly between $2 \%$ and $20 \%$ (Figs. 2 and 3 and Appendix Table 2). At Site 745 , the generalized concentration pattern largely follows that of the bulk terrigenous material. The quartz/feldspar ratio correlates with the quartz concentrations, indicating that the feldspar influx was fairly constant.

\section{Grain-Size Distribution of Terrigenous Matter}

The gravel component ( $>2 \mathrm{~mm}$ ) of the investigated deep-sea sediments is thought to be of ice-rafted origin. The number of clasts in the samples analyzed (for 1.5-m intervals) is combined with the number of gravel clasts per section $(1.5 \mathrm{~m})$ of core based on the visual core descriptions (Figs. 4 and 5). The latter data provide a statistically better founded picture of ice rafting, 


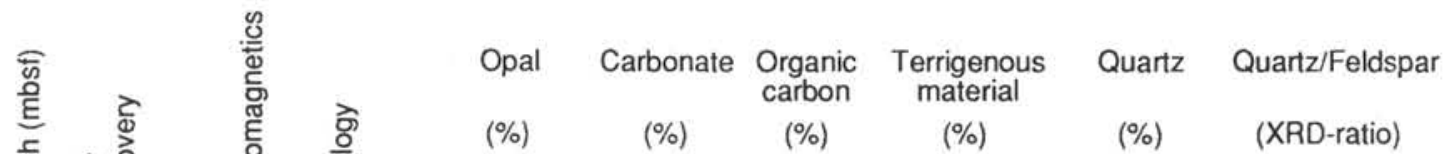

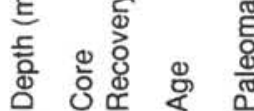
(\%)
(\%)
(\%)
(\%)
(XRD-ratio)

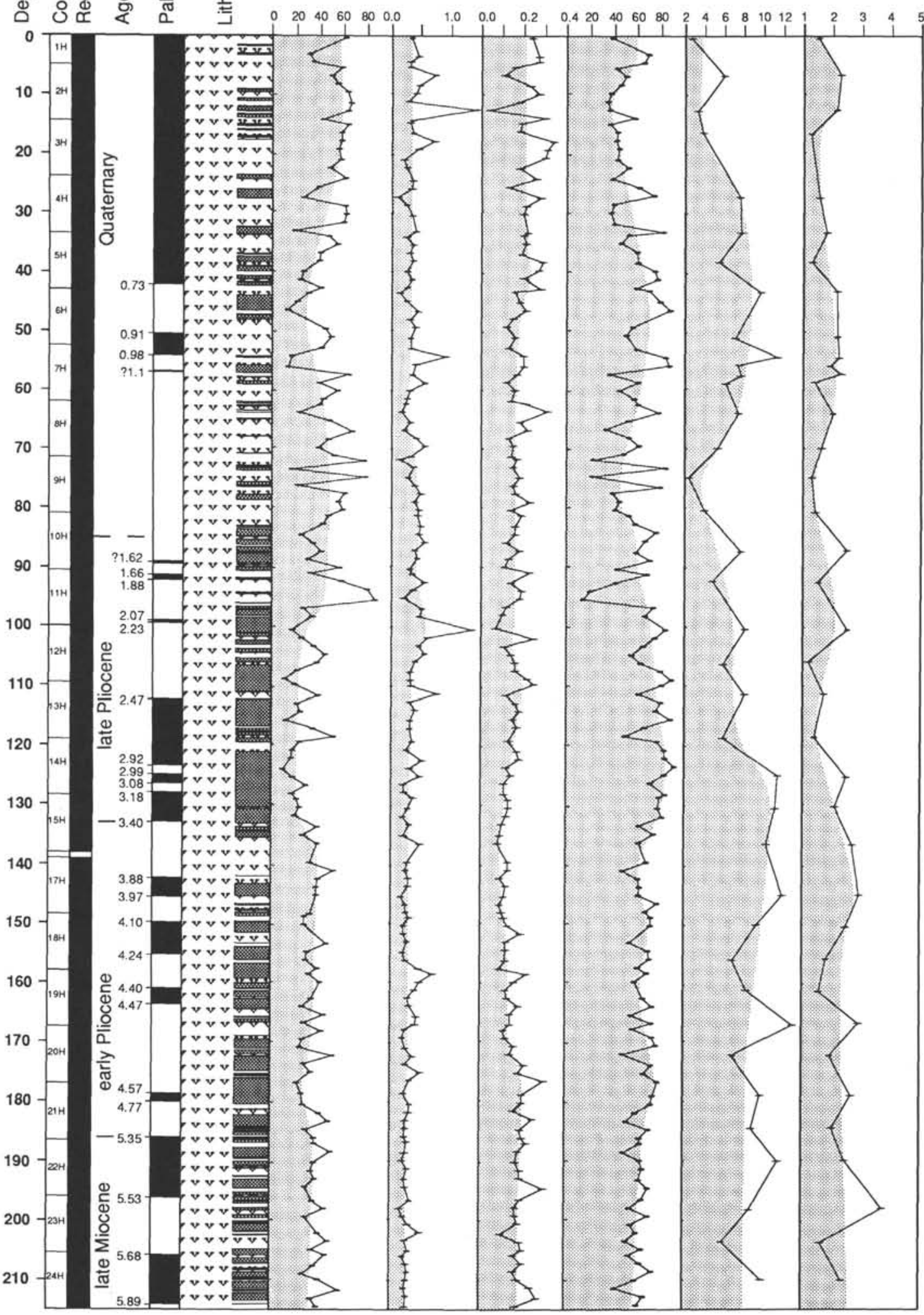

Figure 2. Sediment composition at Site 745. The lithology column shows the cyclic alternations of clayey diatom oozes (facies A) and diatomaceous clays (facies B, dark bars). The paleomagnetic data are courtesy of $\mathrm{H}$. Sakai, and the absolute ages are adapted from Berggren et al. (1985). All data are given in weight percentages, except for quartz/feldspar in XRD peak-area ratios. 


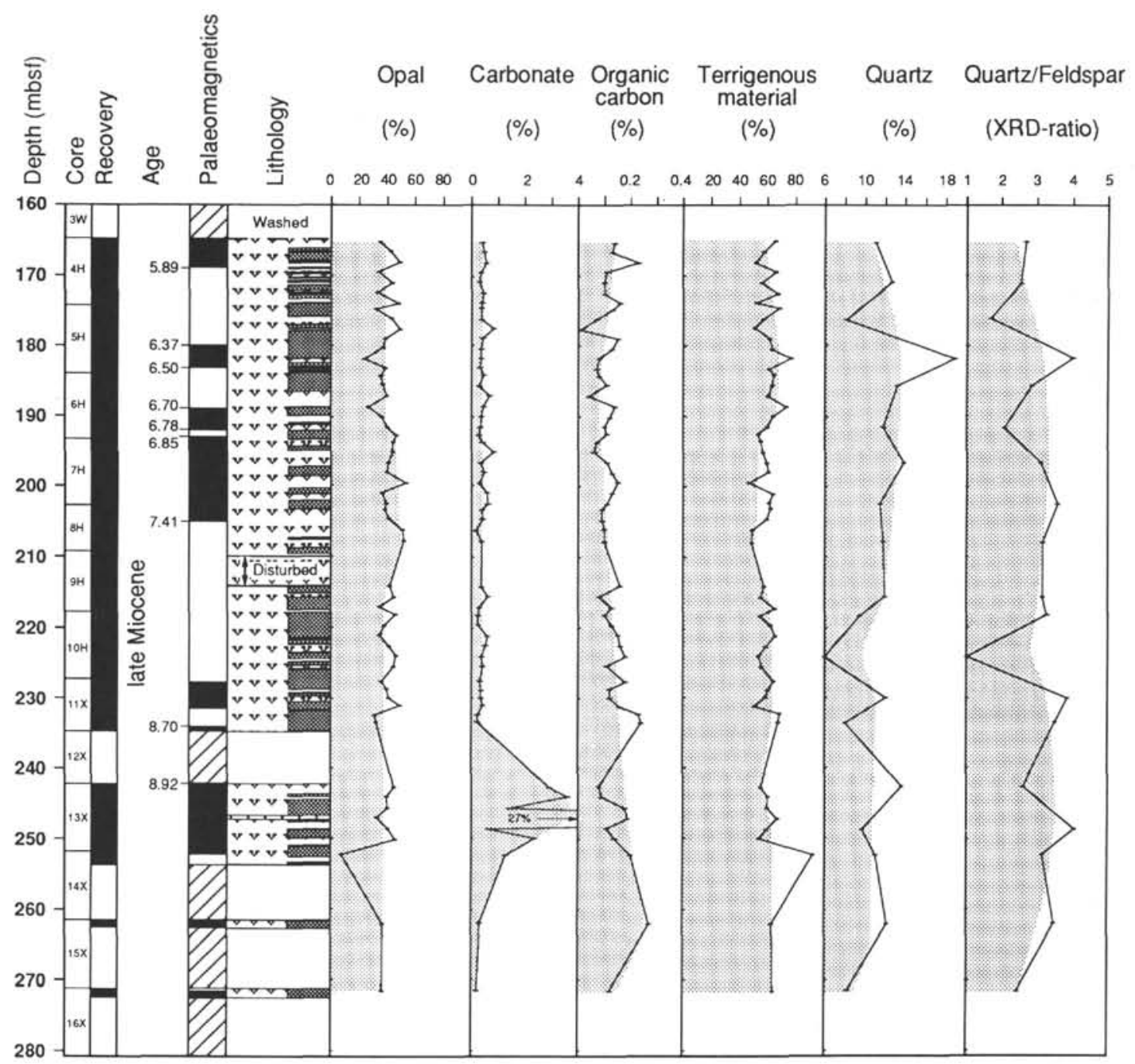

Figure 3. Sediment composition at Site 746. The lithology column shows the cyclic alternations of clayey diatom oozes (facies A) and diatomaceous clays (facies B, dark bars). The paleomagnetic data are courtesy of H. Sakai, and the absolute ages are adapted from Berggren et al. (1985). All data are given in weight percentages, except for quartz/feldspar in XRD peak-area ratios.

because all clasts visible on the cut surface of the core were registered, whereas in the small-volume samples the number of clasts recovered may not be representative. The two curves, however, show a similar general pattern and complement each other. We decided against calculating weight percentages because the number of clasts is more informative than that measure.

With the exception of about the upper 50 -m section at Site 745 , minor amounts of gravel occur almost throughout the two sites (Figs. 4 and 5 and Appendix Tables 3 and 4). The deepest abundant occurrence of gravel is found at Site 746 from 234 to 216 mbsf. The uppermost, much less distinct maximum at Site 746 occurs between 187 and 172 mbsf. In the lower part of Site 745 maxima in the gravel content are found at 183-160 and 149120 mbsf. Almost no gravel occurs in the upper $120 \mathrm{~m}$ at Site 745 . Small amounts are restricted to the intervals at $110-88$ and 73-54 mbsf. The generalized distribution pattern of terrigenous sand ( $2 \mathrm{~mm}-63 \mu \mathrm{m})$ strongly correlates with the gravel content (Figs. 4, 5, and 8). The highest concentrations are about 5\%, but the majority of the samples contain only $0 \%-2 \%$ terrigenous sand.
The clay component $(<2 \mu \mathrm{m})$ accounts for about $60 \%-80 \%$ of the terrigenous material, and silt $(2-63 \mu \mathrm{m})$ for about $20 \%$ $40 \%$ (Figs. 4 and 5 and Appendix Table 4). Both show large variations within short vertical distances according to the cyclic facies changes. Changes of longer term in the silt and clay distribution are not obvious, except for slightly lower average silt concentrations at the bottom and top of Site 746 and a maximum at Site 745 at $60-40$ mbsf. The amplitudes of the smallscale fluctuations of the silt and clay concentrations are much smaller in the upper approximately $110 \mathrm{~m}$ at Site 745 than in the lower part of this site or at Site 746 (Figs. 4 and 5).

\section{Clay Mineralogy}

The concentration of terrigenous clay in the bulk sediment (Figs. 6 and 7 and Appendix Table 5), as well as of silt (which is not presented), shows the same distribution pattern as that of the bulk terrigenous material (Figs. 2 and 3). Silt concentrations fluctuate between $0 \%$ and $40 \%$, and mostly between $10 \%$ and $25 \%$. The clay content varies much more $(0 \%-70 \%)$, with the most abundant concentrations occurring between $25 \%$ and $60 \%$. The clay fraction also reveals the same change in amplitude ob- 


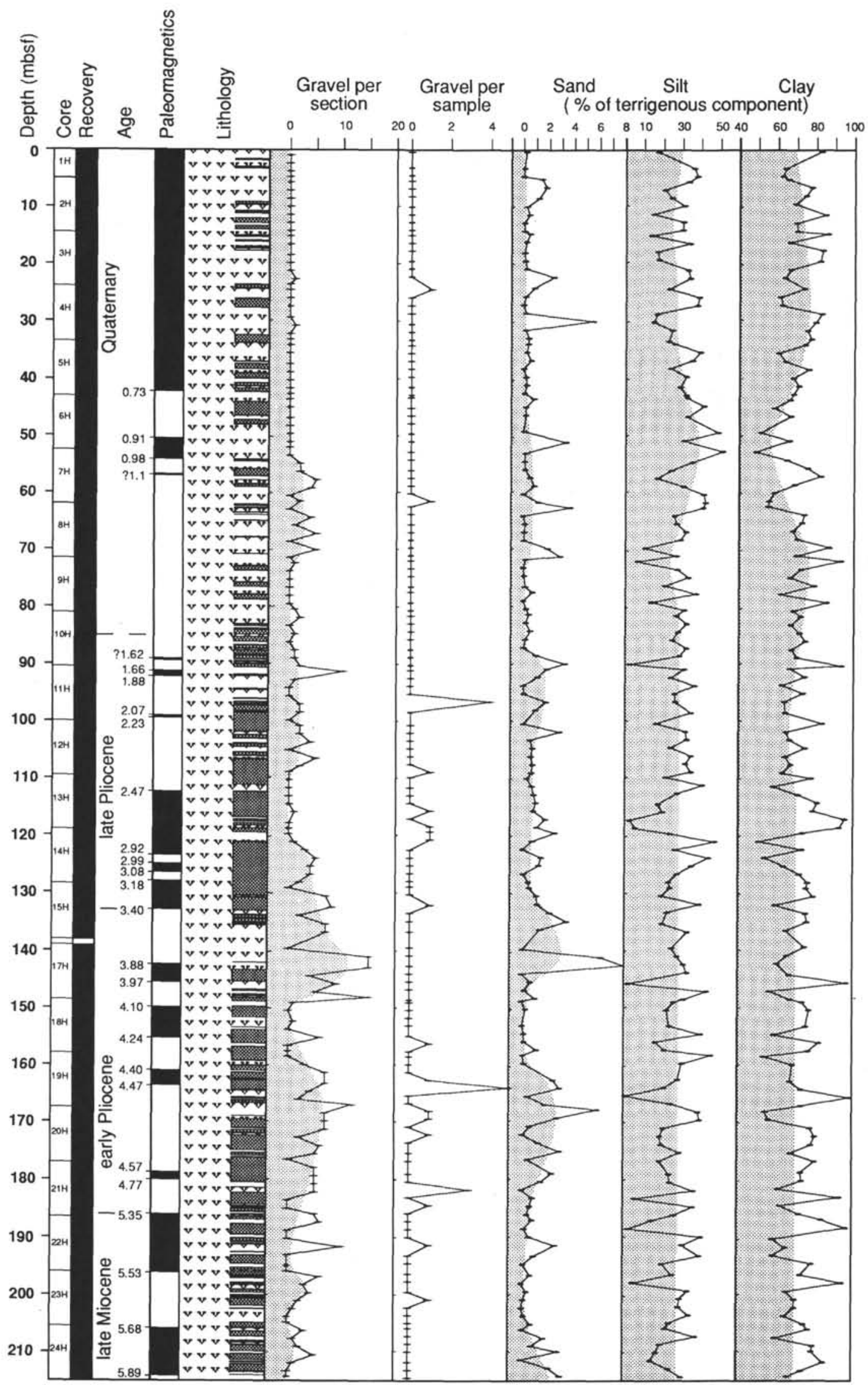

Figure 4. Gravel content and grain-size distribution of the terrigenous sediment components at Site 745. 


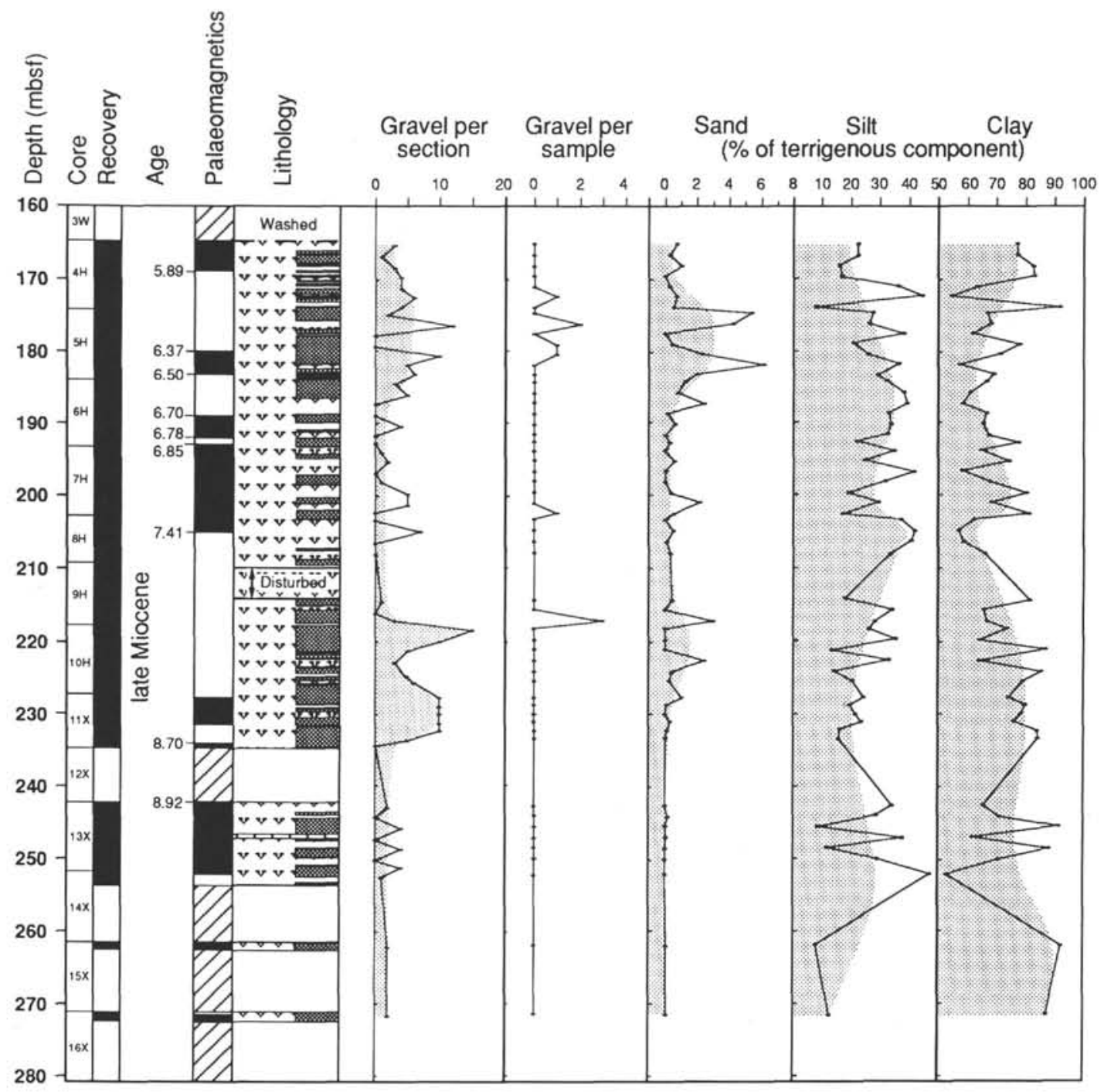

Figure 5. Gravel content and grain-size distribution of the terrigenous sediment components at Site 746.

served in the opaline and bulk terrigenous material concentration plots, but is less distinct.

The smectite-type clay minerals show only minor long-term changes, but have strong short-term changes caused by the cyclic sedimentation, with the highest values found in the facies A intervals. There is a slight increase from $10 \%$ to $20 \%$ from the bottom to the top at Site 746 . At Site 745 , relatively constant mean values of $20 \%$ occur up to 125 mbsf, an indistinct maximum appears at 125-95 mbsf, and a slightly higher and constant concentration level of $25 \%$ is between 95 and 0 mbsf.

At Site 746 the illite concentrations range between $50 \%$ and $70 \%$ with slight maxima at 233-215 and 203-175 mbsf (Fig. 7). Relatively constant concentrations of $50 \%$ occur at the top of Site 746 and the base of Site 745 (Fig. 6). The highest illite concentrations $(70 \%)$ at the two sites occur at $170-125$ mbsf, with a minimum at 125-100 mbsf. Throughout the upper part of the sites the average concentration is about $55 \%$.

The chlorite concentrations are much lower than those of illite, and no significant correlation can be calculated. However, the trend is generally opposite to that of illite (Figs. 6 and 7).

Kaolinite at Site 746 shows a general trend parallel to that of illite and opposite to that of chlorite. In contrast, in the lower approximately $50 \mathrm{~m}$ of Site 745 , kaolinite instead follows the chlorite trend. In the upper part of Site 745 no correlation at all can be recognized. In general, kaolinite reveals a more complicated concentration pattern than that of the other clay minerals (Figs. 6 and 7).

\section{ENVIRONMENTAL SETTING}

The various data described in the preceding provide information that can be incorporated into a reconstruction of the paleoceanography of the Australian-Antarctic Basin. Sites 745 and 746 are just east of the steep southeastern flank of the Kerguelen Plateau (Fig. 1). They are beneath the present-day Antarctic Bottom Water (AABW; Emery and Meincke, 1986). The surface water mass of the region is Antarctic Surface Water (AASW; Emery and Meincke, 1986). The water mass intercalated between AABW and AASW is Circumpolar Deep Water (CDW).

The Kerguelen region is one of the most variable areas of the Southern Ocean in respect to its hydrography (Deacon, 1983). There is little doubt that the Polar Front, a major water-mass boundary that separates the cold AASW in the south from warmer Subantarctic Surface Water (SASW) to the north, runs close to Kerguelen Island (Deacon, 1983; Whitworth, 1988; Fig. 1). It is not clear, however, whether it is generally north or south 


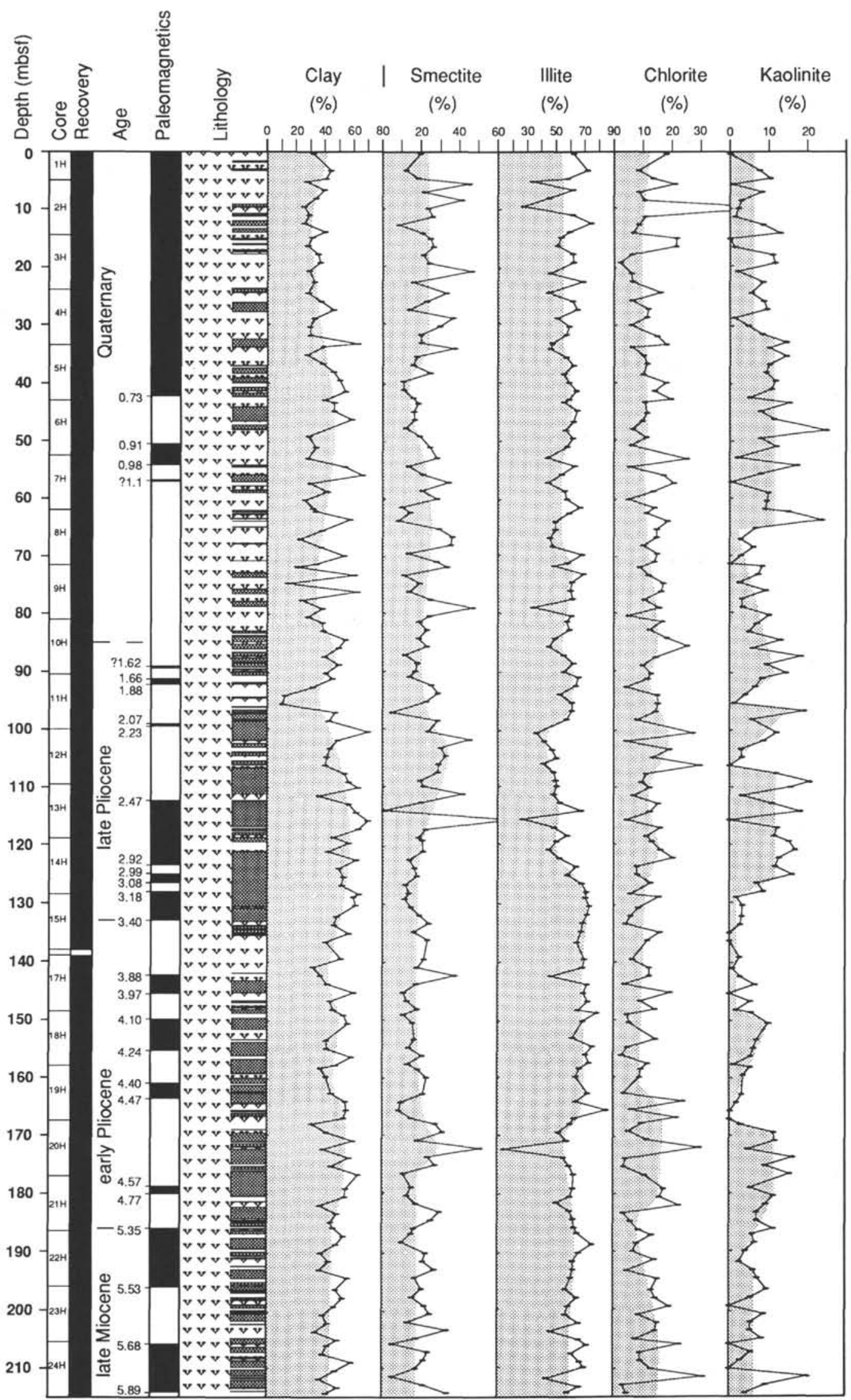

Figure 6. Amount of terrigenous clay (nonbiogenic, $<2 \mu \mathrm{m}$ ) and relative percentages of individual clay minerals at Site 745. 


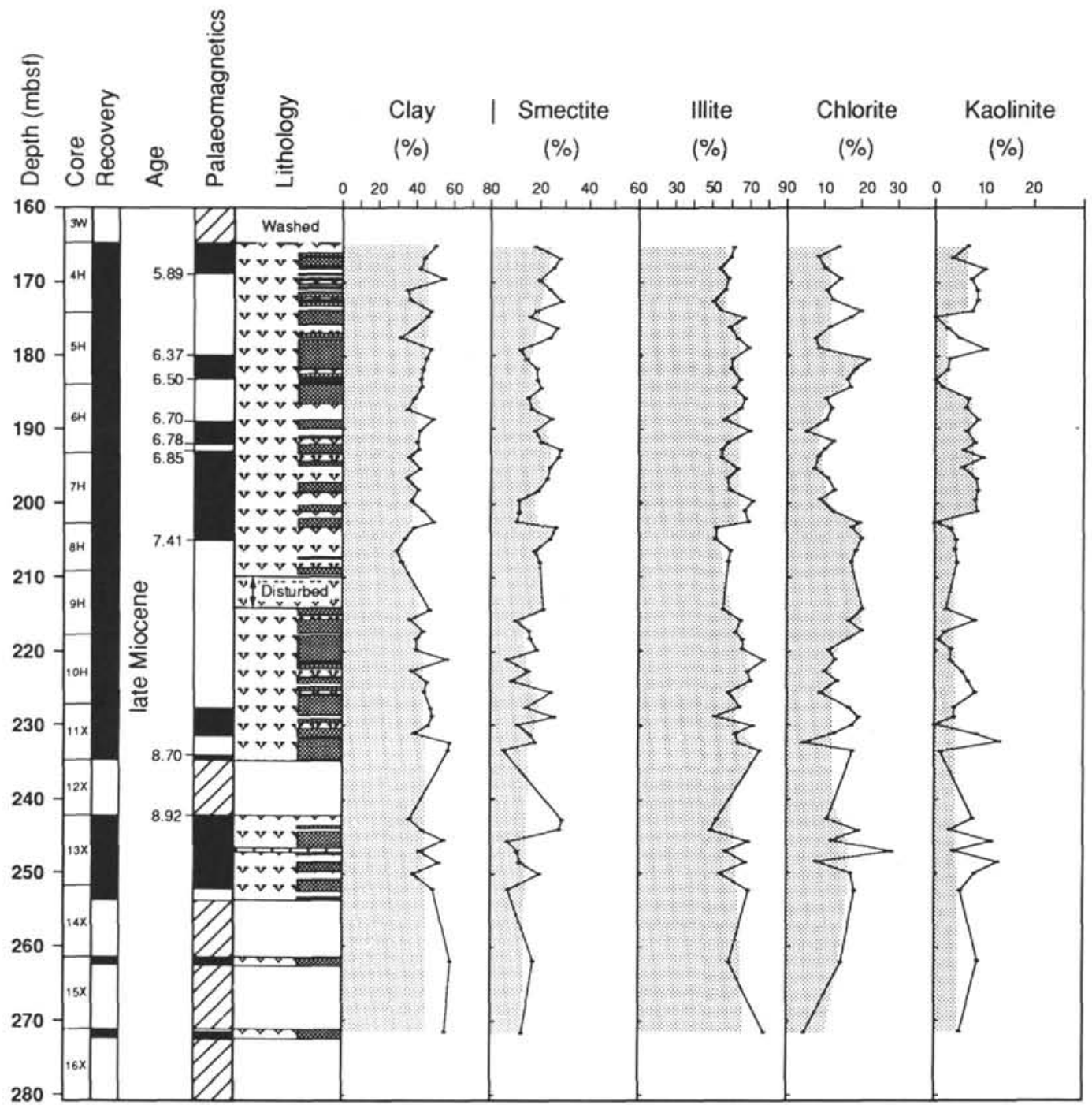

Figure 7. Amount of terrigenous clay (nonbiogenic, $<2 \mu \mathrm{m}$ ) and relative percentages of individual clay minerals at Site 746.

of the island and how much it fluctuated in the past. It seems to be meandering, with a southward bend between Kerguelen Island and Heard Island (Deacon, 1983).

Another important hydrographic front, the Antarctic Divergence, is south of the sites at about $65^{\circ} \mathrm{S}$. It separates the west wind-driven Antarctic Circumpolar Current (ACC; Whitworth, 1988) from the east wind-driven Antarctic Coastal Current. The ACC could not have been established before the opening of the Drake Passage sometime in the late Oligocene/early Miocene (Wise et al., 1985). This current circles the Antarctic continent and plays an important role in isolating it thermally. The Neogene Antarctic cooling is a direct consequence of this isolation.

The buildup of large ice shelves and expansion of sea ice in late Miocene time resulted in the initiation of modern AABW formation (Ciesielski et al., 1982) and thereafter another major change in the circulation pattern. The processes responsible for AABW formation are discussed by Gordon $(1978,1982)$, Foster and Carmack (1976), Foster and Middleton (1979), Foster et al. (1987), Foldvik et al. (1985), and Foldvik and Gammelsrød (1988). To summarize, AABW formation generally is linked to the cooling of water beneath large floating ice shelves, cooling in polynyas kept open in front of the ice shelf edge by katabatic winds, or to a combination of these processes.
Bottom currents were active throughout, especially during the interglacial periods, and redistributed the sediment by winnowing of the fine-grained sediment particles (Barron, Larsen, et al., 1989; Ehrmann and Grobe, this volume). Significant hiatuses indicating strong, erosive bottom currents and removal of parts of the sedimentary sequence, however, were not recorded at Sites 745 and 746.

No major change in the accumulation patterns can be seen in the sediments recovered at Sites 745 and 746. The upper Miocene to Quaternary sediments have a pelagic, mixed biosiliceous and terrigenous character. They consist almost entirely of alternating clayey diatom ooze and diatomaceous clay. The processes responsible for the cyclic facies changes ultimately can be attributed to advances and retreats of the ice shelves. Transport by gravity, ice, and current and input as a result of primary productivity are the most important factors (Ehrmann and Grobe, this volume).

The only deviation from this sedimentation pattern is documented by a nannofossil ooze with abundant Reticulofenestra perplexa and common Coccolithus pelagicus, which are of little age-diagnostic value (Barron, Larsen, et al., 1989). Paleomagnetic data give an age of $9.2 \mathrm{Ma}$. The ooze is approximately 60 $\mathrm{cm}$ thick and has gradational transitions to the underlying and 
overlying sediments. It is intensely bioturbated in the middle and moderately bioturbated on its marginal parts. Carbonate content reaches $65 \%$ in the center of the interval. Also, the samples from up to $4.5 \mathrm{~m}$ below and above the ooze reveal carbonate concentrations that are higher than the background level (Fig. 3). The nannofossils are strongly etched (Barron, Larsen, et al., 1989). These characteristics make transport by turbidity currents from the Kerguelen Plateau questionable. It seems rather that the ooze represents a phase of enhanced primary calcareous production and deposition above the carbonate critical depth (CCrD; Kolla et al., 1976). This in turn would imply that the $\mathrm{CCrD}$, and probably also the carbonate compensation depth (CCD), were in a deeper position than today (CCrD: $~ 3900 \mathrm{~m}-$ Kolla et al., 1976; CCD: $\sim 5200 \mathrm{~m}$-Van Andel, 1975). The ooze is possibly indicative of the situation that existed before present-day deep-water circulation was established with the initiation of AABW formation in late Miocene time. This change would also have influenced the depth of the CCD and CCrD. However, the poor recovery below the nannofossil ooze and abandonment of the hole prevents us from testing this hypothesis.

\section{ORIGIN OF ICE-RAFTED DEBRIS}

The Kerguelen Plateau with its widespread volcanism and islands is not a likely source for the sediment particles deposited at Sites 745 and 746, which lie just east of the plateau. Sedimentary clasts and basaltic components, which could be derived from the plateau, are totally missing. All the gravel and sandsize rock fragments are of gneissic and, to a minor degree, of granitic character, resembling the material found at the Prydz Bay sites. Even the terrigenous sand and silt grains do not indicate a different source.

The clay minerals also indicate a source area on the Antarctic continent. The clay fraction of the sediments is dominated by illite, which, together with chlorite, was most probably the product of physical weathering and glacial scour of igneous rocks, such as those widespread in East Antarctica (e.g., Ravich et al., 1984). The different clay mineral assemblages found at Sites 745 and 746 can be used to speculate on the source area.

Kaolinite, which cannot form under glacial conditions, is thought to be derived from the erosion of old sedimentary rocks or soils. The Permian Amery Formation or equivalent rocks that may have occupied the Lambert Graben may be a possible source. The Amery Formation containing feldspathic sandstones with a kaolinitic matrix (Trail and McLeod, 1969) crops out at Beaver Lake, which is just east of the main stream of the Lambert Glacier, close to the present-day coastline. Its extension beneath the ice is not known, but a thick sedimentary sequence probably accumulated in the now ice-filled Lambert Graben. This source also may strongly influence the clay mineralogy at the Prydz Bay Sites 739-743 in front of the Amery Ice Shelf complex (Hambrey et al., this volume). Other possible kaolinitic sediments in East Antarctica may occur in the Beacon Supergroup in the Transantarctic Mountains (Barrett et al., 1986) and on George V Coast, far away from Sites 745 and 746 (Craddock, 1982).

In addition to kaolinitic sediments, the hinterland of Prydz Bay, as most of East Antarctica, is characterized by large areas of migmatite and biotite-quartz-feldspar gneiss and some small areas of charnockite. Farther inland, quartzites and quartzmica schists occur (Trail and McLeod, 1969; Craddock, 1982; Ravich and Fedorov, 1982). The typical clay mineral assemblage derived from this region should be composed of illite and minor amounts of chlorite, with kaolinite as the diagnostic mineral. Because the kaolinite content correlates slightly with the chlorite content at Site $\mathbf{7 4 6}$, but with the illite content in the lower part of Site 745, and with no other clay mineral in the upper part of this site (Figs. 6 and 7), several source areas must be assumed.

The two clay mineral families illite and chlorite show a slight negative correlation at Sites 745 and 746 . Two source areas each with a different principal lithology can be assumed. Chlorites are characteristic of low-grade metamorphic and basic rocks, whereas illites may indicate more acidic source rocks (Griffin et al., 1968). The described lithology from East Antarctica, however, does not show such major variations, and Precambrian gneisses and schists are dominant. Some Precambrian charnockite bodies have also been found (Craddock, 1982; Ravich and Fedorov, 1982). Thus, there is little possibility of defining different source areas, especially because the greater part of the continent is under ice. Our knowledge of the lithology is thus restricted to a number of small ice-free areas along the coast. The concentration patterns of the glacially derived clay minerals illite, chlorite, and especially of kaolinite (Figs. 6 and 7) indicate frequently changing intensities in the influence of the different source areas.

The fine-grained clay minerals may have been derived directly as a result of drifting icebergs. They might also have been transported down the continental slope by gravitational transport, or by currents that took up their suspension load on the slope and released it in the deep-sea basin. Once deposited on the ocean floor, these fine-grained sediment particles were prone to winnowing by bottom currents. Therefore, the changing concentrations of the individual clay minerals are not thought to represent fluctuations in the intensity of glaciation in different parts of East Antarctica. Rather, they are due to a complex interaction of different transport mechanisms, which in turn may be controlled by climate and glacial processes.

\section{GLACIAL HISTORY}

The sedimentological data presented here can be used to decipher the glacial history of the East Antarctic margin. Especially the discussion of the growth and decay of ice shelves and the intensity of ice rafting in the Southern Ocean finds further support (Fig. 8). The nature and origin of the cyclic facies changes and their implications are discussed by Ehrmann and Grobe (this volume).

Sites 745 and 746 are within an area influenced by drifting icebergs, as experienced during JOIDES Resolution drilling operations. Indeed, within only four days on site, four big icebergs approached the ship and caused drilling interruptions. Ice rafting at the site locations is controlled by the density of icebergs and thus calving processes. These, in turn, are controlled by sea-level changes and the mass budget of the Antarctic Ice Sheet in response to climatic changes.

Ice-rafted debris at present is delivered mainly by icebergs calving into the sea from ice streams and outlet glaciers (Drewry, 1986). At the base of an ice shelf with its grounding line close to the continent, all terrigenous material melts out and settles on the continental shelf soon after it leaves the grounding line. An exception occurs when freeze-on of saline ice onto the base of the ice shelf traps the sediment until the ice front is reached. Generally, however, because of melting at the base and snowfall on the ice shelf, icebergs calving from larger ice shelves consist mainly of younger "clean" snow and ice.

However, scenarios also exist for ice shelves producing "dirty" icebergs. If the grounding line is situated close to the continental shelf break and the floating ice tongue is smaller, the basal glacial debris may not yet have been rained out when icebergs calve, and thus can be transported to distal regions. Another exception occurs when a grounded ice sheet, with sediment incorporated in its base, decouples from the continental shelf as a re- 


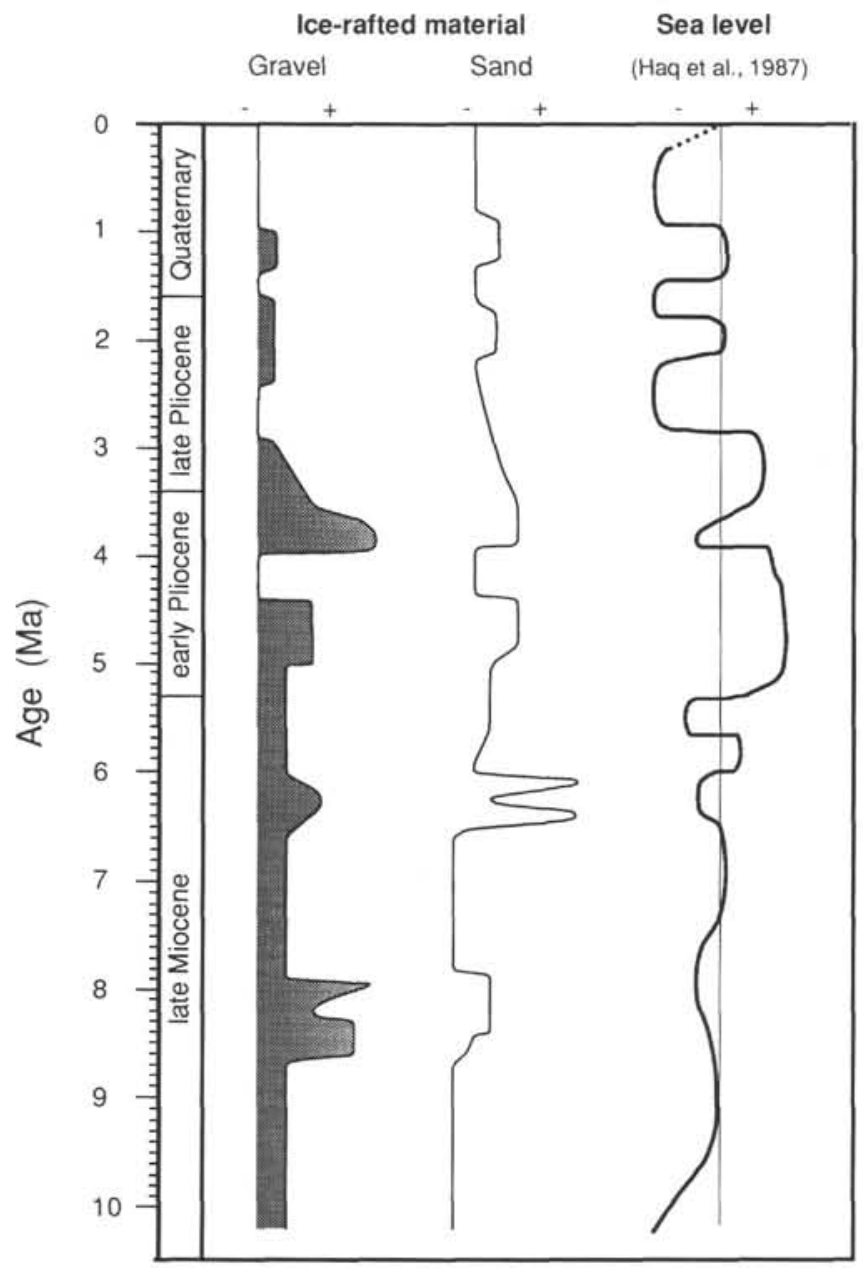

Figure 8. Generalized plot of ice-rafted terrigenous gravel and sand content vs. age in comparison to the sea-level curve (Haq et al., 1987).

sult of a sea-level rise, becomes unstable, and breaks into pieces, which then drift away. Surface sediments on the continental shelf can also be picked up by drifting and periodically grounded icebergs and transported for short or long distances to the continental margin.

We believe that the intensity of ice-rafting through time is reflected in the content of gravel and terrigenous sand. Detailed studies showed that the concentration patterns of those two parameters are not a dilution effect and also that small concentration patterns are diagnostic (Ehrmann and Grobe, this volume). The gravel content and the terrigenous sand content correlate across large intervals at Sites 745 and 746 (Figs. 4, 5, and 8). It is obvious that ice rafting was active throughout the time represented by the recovered sediments (i.e., about $10 \mathrm{Ma}$ ). Ice rafting was not always of the same intensity, but was accentuated at certain times. The intensity was greatest in late Miocene and early Pliocene time. Maxima occur at 8.7-7.9, 6.6-6.0, 5.0-4.4, and 4.0-3.2 Ma (Fig. 8). More recent ice-rafted material is also present, but in smaller amounts, and is mainly represented by the sand fraction. It seems, however, that ice rafting of sediments was lower during the last approximately $3 \mathrm{Ma}$. The fluctuations in the amount of ice-rafted material at Sites 745 and 746 can be correlated with the growth and decay phases of ice shelves. Superimposed on these large trends of ice advances and retreats are the shorter term glacial-interglacial cycles (Ehrmann and Grobe, this volume).

\section{Middle Late Miocene}

The first recorded maximum of ice-rafted debris at Sites 745 and 746 in the Australian-Antarctic Basin occurs at 8.7-7.9 Ma (Fig. 8). It coincides with thick diatomaceous clay intervals (facies B, Fig. 5), which indicate a paleoceanographic setting characterized by extended ice shelves (Ehrmann and Grobe, this volume). The beginning of this maximum of ice rafting is somewhat disguised because of poor recovery rates for sediments $>8.7 \mathrm{Ma}$ (Fig. 5). At about the same time, a glacial event is also documented as an increase in the intensity of ice rafting at 9.4 $\mathrm{Ma}$ at Sites 744 and 738 on the southern Kerguelen Plateau (Ehrmann, this volume). In contrast to the sites in the Australian-Antarctic Basin, ice-rafting on the Kerguelen Plateau seems to have continued at the same intensity until recent times. Sedimentation rates on the Kerguelen Plateau are probably too low to allow resolution of the individual maxima. Icebergs drifting over Kerguelen Plateau theoretically could be derived from a different source area and originated predominantly from calving outlet glaciers or ice streams, which contain larger amounts of terrigenous debris than do icebergs calving from ice shelves (Drewry, 1986). The present-day oceanographic setting, however, makes a different source for icebergs reaching Sites 745 and 746 , respective of Sites 738 and 744 , not very likely.

The ice advance of $8.7-7.9 \mathrm{Ma}$ is connected with the pronounced buildup of ice shelves around Antarctica that occurred at about that time. The late Miocene was a time of maximum ice volume and ice discharge from the ice sheet since its initiation (Robin, 1988). Expansions of the ice shelves are recorded from the Ross Sea drill hole MSSTS-1 (Barrett, 1986) and Deep Sea Drilling Project (DSDP) Sites 270, 272, and 273 (Savage and Ciesielski, 1983). Large ice shelves also formed in late Miocene time in the Weddell Sea (Ciesielski et al., 1982; Mercer, 1983). In Prydz Bay an erosional hiatus spanning the late Oligocene to early late Miocene indicates a major ice advance (Hambrey et al., this volume). The sediments above the hiatus are dated as part of the Thalassiosira torokina Zone (7.7-4.8 Ma; Baldauf and Barron, this volume). Enhanced ice discharge from extended ice shelves with their grounding lines close to the shelf break would favor the generation of icebergs laden with debris that was incorporated as the ice advanced across the continental shelf. This hypothesis of an increase of global ice volume and global cooling finds further support in a late Miocene increase of $\delta^{18} \mathrm{O}$ values in planktonic foraminifers recorded in the southwestern Pacific (Shackleton and Kennett, 1975) and in a fall of the sea level (Haq et al., 1987; Fig. 8).

The maximum of ice rafting at 8.7-7.9 Ma appears exactly at the same time $(8.7 \mathrm{Ma})$ as the oldest ice-rafted material at DSDP Site 513 in the southwestern Atlantic Ocean (Bornhold, 1983; Ciesielski and Weaver, 1983) and approximately at the same time as the oldest ice-rafted material at DSDP Site 274 in the Ross Sea (Barrett, 1975). A further correlation exists to deep-sea hiatus NH5 (8.6-8.0 Ma; Keller and Barron, 1987), which can be attributed either to a cooling in the antarctic region resulting in an intensification of the ACC or to an intensification of bottom water flow. The bottom water circulation in the oceans became more violent because of the injection of AABW formed as a result of the large ice shelves and possibly the expansion of sea ice.

\section{Late Miocene to Early Pliocene Transition}

The deposition of upper Miocene and lower Pliocene proximal tills and distal glaciomarine sediments at the Prydz Bay Sites 738 and 742 indicates that during that time the grounding line of the Lambert Glacier/Amery Ice Shelf complex was fluctuating and that the ice shelf temporarily had a larger extension than at present day (Hambrey et al., this volume). An exact dat- 
ing of ice advances and retreats, however, is not possible based on the Prydz Bay sites. Nor does the sedimentary record in the Ross Sea allow dating of the latest Miocene to early Pliocene growth and decay phases of the ice shelf (Barrett, 1986, 1989; Hayes, Frakes, et al., 1975).

The ice-rafting maximum at 6.6-6.0 Ma recorded at Site 746 (Fig. 8) occurs within a core section characterized by thick facies B intervals, which implicate a redeposition of material from the continental shelf. In contrast to the Quaternary cycles, in this older part of the sequence the facies B intervals contain enhanced gravel and terrigenous sand concentrations. Therefore, the terrigenous portion of the sediments is assumed to have been transported by icebergs rather than by turbidites, which allow only the fine fraction of the sediment load to reach the distal Site 746 (Ehrmann and Grobe, this volume).

A possible explanation for this scenario could be found in a rise of sea level resulting in a decoupling of the ice sheet from the continental shelf and a break-up into many icebergs, which carry basal debris. According to Haq et al. (1987) the rise of sea level had already started by $7.5 \mathrm{Ma}$ and reached a maximum at 7.0-6.8 Ma. At 6.6-6.0 Ma, however, the sea level seems to have been low (Fig. 8). In contrast, a shift in the oxygen isotope composition of planktonic foraminifers from Site 751 on the Kerguelen Plateau to lighter values is interpreted as an indicator for a rise in the sea level and/or a warmer surface water temperature at around 6.1 Ma (Mackensen et al., in press). The simultaneous increase of the $\delta^{18} \mathrm{O}$ values of benthic foraminifers is thought to be a result of cooling of the deeper water mass because of increased bottom water production beneath floating ice shelves (Mackensen et al., in press). The increased AABW formation beneath floating ice shelves also could be an explanation for deep-sea hiatus NH6 (7.0-6.0 Ma; Keller and Barron, 1987).

The maximum in ice rafting at 6.6-6.0 Ma predates the late Miocene $\delta^{13} \mathrm{C}$ shift to lighter values, which is documented in almost all oceans (Keigwin, 1979; Vincent et al., 1980; Savin et al., 1981; Mackensen et al., in press) and has an age of 6.1-5.9 $\mathrm{Ma}$ (Williams et al., 1988). Vincent et al. (1980) suggested that this shift was the result of a regression. A regression would have resulted in a stabilization of the ice shelves and a decrease in calving activity. This effect could have caused the cease of significant ice rafting at approximately $6.0 \mathrm{Ma}$.

The next clearly defined event in ice-rafting activity occurs at 5.0-4.4 Ma and is recorded in sediments from Site 745 by an enhanced content of gravel and terrigenous sand (Fig. 8). The paleomagnetic data (H. Sakai, pers. comm., 1989) indicate the highest sedimentation rates of the stratigraphic sequence for the interval between 4.6 and $4.4 \mathrm{Ma}$ (Fig. 4).

The sea-level curve of Haq et al. (1987) reports a drastic rise in sea level at about 5.0 Ma (Fig. 8), probably as a result of a strong early Pliocene deglaciation (e.g., Ciesielski et al., 1982; Hodell and Kennett, 1986; Pickard et al., 1988). The decay of the ice shelves led to enhanced calving of icebergs and enhanced input of fine and coarse ice-rafted debris. The floating ice in the initial phase of the decay of the ice shelves again could have favored the formation of AABW responsible for deep-sea hiatus NH7 (Keller and Barron, 1987).

Approximately 4.5-3.5-Ma-old glaciomarine sediments containing abundant diatoms and mollusks were recorded from Marine Plain, an area at the eastern coast of Prydz Bay (Pickard et al., 1988). These sediments were deposited under a warmer climate than today and in shallow water off an open coast. Thus, the ice margin may have been $\sim 50 \mathrm{~km}$ farther inland than today (Pickard et al., 1988). This implies that the decay of the ice shelf was completed by that time.

\section{Early Pliocene to Late Pliocene Transition}

The maximum of ice-rafted gravel and terrigenous sand at Site 745 spanning the time interval 4.0-3.2 Ma coincides with a fall of sea level (Haq et al., 1987; Fig. 8) indicating a fixation of water in ice on the Antarctic continent or in the ice shelves. Expansions of ice shelves and sea ice are recorded from West Antarctica, along the East Antarctic margin, and possibly in marine embayments of East Antarctica (Ciesielski and Grinstead, 1986).

The glaciers and ice shelves expanding after the pronounced early Pliocene deglaciation incorporated large amounts of debris, which were deposited in the coastal areas and on the continental shelf during the deglaciation, into their base. Icebergs calving from glaciers into the sea could transport this material directly to the site of deposition. Icebergs calving from the ice shelves would require that the grounding line be situated close to the shelf break to prevent the loss of all basal debris by melting processes before calving. Such a setting is likely for that time. A greater influx of ice-rafted debris into the oceans at this time has also been found in the southwest Atlantic Ocean (Bornhold, 1983) and in the southeast Indian Ocean (Blank and Margolis, 1975).

An intensification of the ACC at about 4.0-3.2 Ma, as postulated by Ciesielski et al. (1982), is linked with a cooling phase, which is reported, for example, by Abelmann et al. (in press), and which also resulted in the buildup of an ice cap in Patagonia at about 3.2 Ma (Mercer, 1976). Deep-sea hiatus NH8 (3.73.2 Ma; Keller and Barron, 1987) is possibly another result of the intensification of the ACC.

\section{Late Pliocene to Holocene}

Minor amounts of ice-rafted debris have accumulated during the approximately last $3 \mathrm{Ma}$. However, the gravel content of the sediments has especially decreased. This shift in the record of coarse ice-rafted material coincides with a distinct fall of sea level at $2.9 \mathrm{Ma}$ (Haq et al., 1987). The lower sea level favored the grounding of large areas of the marginal ice sheet, which in turn produced a relatively stable situation. Most of the terrigenous material, once embedded in the basal part of the ice, was deposited on the continental shelf close to the grounding line. Calving from ice shelves was reduced, and the resultant icebergs carried only minor amounts of glacial debris. As another result, the mainly marine-derived smectites show maximum concentrations between 3 and $2 \mathrm{Ma}$, whereas the glacially derived illites have a minimum concentration. Also, following this maximum, from $2 \mathrm{Ma}$ to Holocene time, the smectite contents are higher and the illite concentrations lower than between 10 and $3 \mathrm{Ma}$. The decrease in the number and thickness of facies B intervals at Site 745 , which occurs at $\sim 2.0 \mathrm{Ma}$ and most dramatically at $\sim 1.5 \mathrm{Ma}$, indicates that most of the glacial debris was trapped on the shelf area, and thus is further evidence for relatively stable ice shelves.

This period of relatively stable ice shelf conditions does not totally lack facies A-B cycles (Fig. 2 and Appendix Table 1). Although they occur less frequently, they are more pronounced than in former times, as indicated by the amplitudes of the fluctuations in the content of terrigenous and opaline matter (Fig. 2 ). In the sediments older than $2.4 \mathrm{Ma}$, the cycles are less clearly defined by changes in sediment composition, but are characterized by changes in grain size (Figs. 4 and 5). Thus, the amplitudes in the grain-size distribution curves are much more pronounced in the deeper part of the sedimentary record.

The intervals characterized by weak maxima in the content of ice-rafted material at 2.4-1.6 and 1.4-1.0 Ma correlate with relatively short-lived and minor rises of sea level at 2.0-1.6 and 1.3-1.0 Ma (Haq et al., 1987; Fig. 8). The sea-level rises may have caused the ice sheets to decouple from the sea bed. Therewith, less stable situations were established and the production of icebergs increased. At the same time, maxima of ice-rafted material are also reported from the southwest Atlantic Ocean (Bornhold, 1983; Ciesielski and Weaver, 1983). 


\section{ACKNOWLEDGMENTS}

The authors thank the master and crew of JOIDES Resolution and the ODP technical staff for their work aboard ship. This study was supported by the Deutsche Forschungsgemeinschaft (DFG, Grant Fu 119/15). It benefited from the constructive criticism of Andreas Mackensen and Michael J. Hambrey, who also improved the English text of an earlier version of this paper. Laboratory work was undertaken mainly with the assistance of A. Hienen, R. Fröhlking, and H. Ulmer. This is Alfred Wegener Institute Contribution no. 274.

\section{REFERENCES}

Abelmann, A., Gersonde, R., and Spiess, V., in press. Pliocene-Pleistocene paleoceanography in the Weddell Sea-siliceous microfossil evidence. In Bleil, U., and Thiede, J. (Eds.), Geologic History of the Polar Oceans: Arctic versus Antarctic: NATO ASI Series.

Barrett, P. D., 1975. Characteristics of pebbles from Cenozoic marine glacial sediments in the Ross Sea (DSDP Sites 270-274) and the South Indian Ocean (Site 265). In Hayes, D. E., Frakes, L. A., et al., Init. Repts. DSDP, 28: Washington (U.S. Govt. Printing Office), 769-784.

(Ed.), 1986. Antarctic Cenozoic History from the MSSTS-1 Drillhole, McMurdo Sound. DSIR Bull., 237.

(Ed.), 1989. Antarctic Cenozoic History from the CIROS-1 Drillhole, McMurdo Sound. DSIR Bull., 245.

Barrett, P. J., Elliott, D. H., and Lindsay, J. F., 1986. The Beacon Supergroup (Devonian-Triassic) and Ferrar Group (Jurassic) in the Beardmore Glacier area, Antarctica. Ant. Res. Ser., 36:339-428.

Barron, J. A., Larsen, B., et al., 1989. Proc. ODP, Init. Repts., 119: College Station, TX (Ocean Drilling Program).

Berggren, W. A., Kent, D. V., Flynn, J. J., and Van Couvering, J. A., 1985. Cenozoic geochronology. Geol. Soc. Am. Bull., 96:1407-1418.

Biscaye, P. E., 1964. Distinction between kaolinite and chlorite in recent sediments by X-ray diffraction. Am. Miner., 49:1281-1289.

1965. Mineralogy and sedimentation of recent deep-sea clays in the Atlantic Ocean and adjacent seas and oceans. Geol. Soc. Am. Bull., 76:803-832.

Blank, R. G., and Margolis, S. V., 1975. Pliocene climatic and glacial history of Antarctica as revealed by southeast Indian Ocean deep-sea cores. Geol. Soc. Am. Bull., 86:1058-1066.

Bornhold, B. D., 1983. Ice-rafted debris in sediments from Leg 71, southwest Atlantic Ocean. In Ludwig, W. J., Krasheninnikov, V. A. et al., Init. Repts. DSDP, 71: Washington (U.S. Govt. Printing Office), 307-316.

Ciesielski, P. F., and Grinstead, G. P., 1986. Pliocene variations in the position of the Antarctic Convergence in the southwest Atlantic. Paleoceanography, 1:197-232.

Ciesielski, P. F., Ledbetter, M. T., and Ellwood, B. B., 1982. The development of Antarctic glaciation and the Neogene paleoenvironment of the Maurice Ewing Bank. Mar. Geol., 46:1-51.

Ciesielski, P. F., and Weaver, F. M., 1983. Neogene and Quaternary paleoenvironmental history of Deep Sea Drilling Project Leg 71 sediments, southwest Atlantic Ocean. In Ludwig, W. J., Krasheninnikov, V. A., et al., Init. Repts. DSDP, 71 (Pt. 1): Washington (U.S. Govt. Printing Office), 461-477.

Craddock, C., 1982. Geological map of Antarctica. In Craddock, C. (Ed.), Antarctic Geoscience: Madison (Univ. Wisconsin Press).

Deacon, G.E.R., 1983. Kerguelen, antarctic and subantarctic. Deep-Sea Res., Part A, 30:77-81.

Dietrich, G., and Ulrich, J., 1968. Atlas zur Ozeanographie: Mannheim (Bibliographisches Institut).

Drewry, D. J., 1986. Glacial Geological Processes: London (Arnold).

Emery, W. J., and Meincke, J., 1986. Global water masses: summary and review. Oceanol. Acta, 9:383-391.

Fisher, R. L., Jantsch, M. Z., and Comer, R. L., 1982. General Bathymetric Chart of the Oceans (GEBCO), Scale 1:10,000.000. 5-9: Ottawa (Canadian Hydrographic Service).

Foldvik, A., and Gammelsrød, T., 1988. Notes on Southern Ocean hydrography, sea-ice and bottom water formation. Palaeogeogr., $\mathrm{Pa}$ laeoclimatol., Palaeoecol., 67:3-17.

Foldvik, A., Gammelsrød, T., and Torresen, T., 1985. Circulation and water masses on the southern Weddell Sea shelf. Antarct. Res. Ser., 43:5-20.
Foster, T. D., and Carmack, E. C., 1976. Frontal Zone mixing and Antarctic Bottom Water formation in the southern Weddell Sea. DeepSea Res., Part A, 23:294-301.

Foster, T. D., Foldvik, A., and Middleton, J. H., 1987. Mixing and bottom water formation in the shelf break region of the southern Weddell Sea. Deep-Sea Res., Part A, 34:1771-1794.

Foster, T. D., and Middleton, J. H., 1979. Variability in the bottom water of the Weddell Sea. Deep-Sea Res., Part A, 26:743-762.

Gordon, A. L., 1978. Deep Antarctic convection west of Maud Rise. J. Phys. Oceanogr., 8:600-612.

1982. Weddell Deep Water variability. J. Mar. Res., 40, Suppl.: 199-217.

Griffin, J. J., Windom, H., and Goldberg, E. D., 1968. The distribution of clay minerals in the world ocean. Deep-Sea Res., Part A, 15: 433-459.

Hambrey, M. J., Larsen, B., Ehrmann, W. U., and Leg 119 Shipboard Scientific Party, 1989. Forty million years of Antarctic glacial history yielded by Leg 119 of the Ocean Drilling Program. Polar Rec., 25:99-106.

Haq, B. U., Hardenbol, J., and Vail, P. R., 1987. Chronology of fluctuating sea levels since the Triassic. Science, 235:1156-1167.

Hayes, D. E., Frakes, L. A., et al., 1975. Init. Repts. DSDP, 28: Washington (U.S. Govt. Printing Office).

Hayes, D. E., and Vogel, M., 1981. General Bathymetric Chart of the Oceans (GEBCO), Scale 1:10,000.000. 5-13: Ottawa (Canadian Hydrographic Service).

Hodell, D. A., and Kennett, J. P., 1986. Late Miocene-early Pliocene stratigraphy and paleoceanography of the South Atlantic and southwest Pacific oceans: a synthesis. Paleoceanography, 1:285-311.

Keigwin, L. D., Jr., 1979. Late Cenozoic stable isotope stratigraphy and paleoceanography of DSDP sites from the east equatorial and central North Pacific Ocean. Earth Planet. Sci. Lett., 45:361-381.

Keller, G., and Barron, J. A., 1987. Paleodepth distribution of Neogene deep-sea hiatuses. Paleoceanography, 2:697-713.

Kolla, V., Bé, A.W.H., and Biscaye, P. E., 1976. Calcium carbonate distribution in the surface sediments of the Indian Ocean. J. Geophys. Res., 81:2605-2616.

Lange, H., 1982. Distribution of chlorite and kaolinite in eastern Atlantic sediments off North Africa. Sedimentology, 29:427-432.

Mackensen, A., Barrera, E., and Hubberten, H.-W., in press. Neogene circulation in the southern Indian Ocean: evidence from benthic foraminiferal assemblages, carbonate, and stable isotopes (ODP Site 751). In Schlich, R., Wise, S. W., et al., Proc. ODP, Sci. Results, 120: College Station, TX (Ocean Drilling Program).

Mercer, J. H., 1976. Glacial history of southernmost South America. Quat. Res., 6:125-166.

1983. Cenozoic glaciations in the Southern Hemisphere. Annu. Rev. Earth Planet. Sci., 11:99-132.

Pickard, J., Adamson, D. A., Harwood, D. M., Miller, G. H., Quilty, P. G., and Dell, R. K., 1988. Early Pliocene marine sediments, coastline, and climate of East Antarctica. Geology, 16:158-161.

Ravich, M. G., and Fedorov, L. V., 1982. Geologic structure of MacRobertson Land and Princess Elizabeth Land, East Antarctica. In Craddock, C. (Ed.), Antarctic Geoscience: Madison (Univ. Wisconsin Press), 499-504.

Ravich, M. G., Solov'ev, D. S., and Fedorov, L. V., 1984. Geological Structure of Mac. Robertson Land (East Antarctica): New Delhi (Amerind Publ.).

Robin, G. de Q., 1988. The Antarctic ice sheet, its history and response to sea level and climatic changes over the past 100 million years. $\mathrm{Pa}$ laeogeogr., Palaeoclimatol., Palaeoecol., 67:31-50.

Savage, M. L., and Ciesielski, P. F., 1983. A revised history of glacial sedimentation in the Ross Sea. In Oliver, R. L., James, P. R., and Jago, J. B. (Eds.), Antarctic Earth Science: Cambridge (Cambridge Univ. Press), 555-559.

Savin, S. M., Douglas, R. G., Keller, G., Killingley, J. S., Shaughnessy, L., Sommer, M. A., Vincent, E., and Woodruff, F., 1981. Miocene benthic foraminiferal isotope record: a synthesis. Mar. Micropaleontol., 6:423-450.

Schlich, R., Wise, S. W, et al., 1989. Proc. ODP, Init. Repts., 120: College Station, TX (Ocean Drilling Program).

Shackleton, N. J., and Kennett, J. P., 1975. Paleotemperature history of the Cenozoic and the initiation of Antarctic glaciation: oxygen and carbon isotope analyses in DSDP Sites 277,279 , and 281. In Ken- 
nett, J. P., Houtz, R. E., et al., Init. Repts. DSDP, 29: Washington (U.S. Govt. Printing Office), 743-755.

Trail, D. S., and McLeod, I. R., 1969. Geology of the Lambert Glacier region. In Craddock, C. (Ed.), Geologic Maps of Antarctica. Am. Geogr. Soc., Antarctic Map Folio Ser., Folio 12.

Van Andel, T. H., 1975. Mesozoic/Cenozoic calcite compensation depth and the global distribution of calcareous sediments. Earth Planet. Sci. Lett., 26:187-194.

Vincent, E., Killingley, J. S., and Berger, W. H., 1980. The Magnetic Epoch-6 carbon shift: a change in the ocean's ${ }^{13} \mathrm{C} /{ }^{12} \mathrm{C}$ ratio 6.2 million years ago. Mar. Micropaleontol., 5:185-203.

Whitworth, T., III, 1988. The Antarctic Circumpolar Current. Oceanus, 31:53-58.
Williams, D. F., Lerche, I., and Full, W. E., 1988. Isotope Chronostratigraphy: Theory and Methods: San Diego (Academic Press).

Wise, S. W., Gombos, A. M., and Muza, J. P., 1985. Cenozoic evolution of polar water masses, southwest Atlantic Ocean. In Hsü, K. J., and Weissert, H. J. (Eds.), South Atlantic Paleoceanography: Cambridge (Cambridge Univ. Press), 283-324.

Date of initial receipt: 13 September 1989

Date of acceptance: 2 February 1990

Ms 119B-208 
APPENDIX

Appendix Table 1. Position of facies B intervals (diatomaceous clays) at ODP Sites $\mathbf{7 4 5}$ and $\mathbf{7 4 6}$ as deduced from the shipboard visual core descriptions and from core photographs.

\begin{tabular}{|c|c|c|}
\hline $\begin{array}{l}\text { Core, section, } \\
\text { interval }(\mathrm{cm})\end{array}$ & $\begin{array}{l}\text { Depth } \\
\text { (mbsf) }\end{array}$ & $\begin{array}{c}\text { Thickness } \\
\text { (m) }\end{array}$ \\
\hline \multicolumn{3}{|l|}{$119-745 \mathrm{~B}-$} \\
\hline $1 \mathrm{H}-2,10-35$ & $1.57-1.81$ & 0.24 \\
\hline $1 \mathrm{H}-3,10-40$ & $3.04-3.33$ & 0.29 \\
\hline $2 \mathrm{H}-3,125$, to $2 \mathrm{H}-4,20$ & $9.13-9.56$ & 0.43 \\
\hline $2 \mathrm{H}-4,135$, to $2 \mathrm{H}-5,25$ & $10.68-11.07$ & 0.39 \\
\hline $2 \mathrm{H}-5,120$, to $2 \mathrm{H}-6,15$ & $11.99-12.43$ & 0.44 \\
\hline $2 \mathrm{H}-6,105$, to $2 \mathrm{H}-7,20$ & $13.30-13.93$ & 0.63 \\
\hline $3 \mathrm{H}-1,55-85$ & $15.05-15.35$ & 0.30 \\
\hline $3 \mathrm{H}-1,140$, to $3 \mathrm{H}-2,12$ & $15.90-16.12$ & 0.22 \\
\hline $3 \mathrm{H}-2,105-135$ & $17.05-17.35$ & 0.30 \\
\hline $3 \mathrm{H}-3,17-23$ & $17.67-17.73$ & 0.06 \\
\hline $3 \mathrm{H}-\mathrm{CC}, 0$, to $4 \mathrm{H}-1,45$ & $23.75-24.44$ & 0.69 \\
\hline $4 \mathrm{H}-2,64$, to $4 \mathrm{H}-3,82$ & $26.08-27.71$ & 1.63 \\
\hline $4 \mathrm{H}-6,90$, to $5 \mathrm{H}-1,15$ & $32.16-33.65$ & 1.49 \\
\hline $5 \mathrm{H}-3,50-62$ & $36.90-37.01$ & 0.12 \\
\hline $5 \mathrm{H}-3,105$, to $5 \mathrm{H}-4,44$ & $37.43-38.30$ & 0.86 \\
\hline $5 \mathrm{H}-4,118$, to $5 \mathrm{H}-5,57$ & $39.01-39.88$ & 0.86 \\
\hline $5 \mathrm{H}-5,145$, to $5 \mathrm{H}-6,55$ & $40.73-41.32$ & 0.58 \\
\hline $5 \mathrm{H}-6,95$, to $5 \mathrm{H}-7,22$ & $41.70-42.45$ & 0.75 \\
\hline $6 \mathrm{H}-1,100$, to $6 \mathrm{H}-3,52$ & $44.00-46.52$ & 2.52 \\
\hline $6 \mathrm{H}-3,120$, to $6 \mathrm{H}-4,55$ & $47.20-48.05$ & 0.85 \\
\hline $7 \mathrm{H}-2,25-54$ & $54.20-54.48$ & 0.28 \\
\hline $7 \mathrm{H}-3,42$, to $7 \mathrm{H}-4,25$ & $55.82-57.11$ & 1.29 \\
\hline $7 \mathrm{H}-4,88-93$ & $57.72-57.77$ & 0.05 \\
\hline $7 \mathrm{H}-5,20-70$ & $58.52-59.00$ & 0.49 \\
\hline $8 \mathrm{H}-1,0-30$ & $62.00-62.29$ & 0.29 \\
\hline $8 \mathrm{H}-1,59-77$ & $62.57-62.75$ & 0.17 \\
\hline $8 \mathrm{H}-2,4-10$ & $63.50-63.55$ & 0.06 \\
\hline $8 \mathrm{H}-2,45-50$ & $63.89-63.94$ & 0.05 \\
\hline $8 \mathrm{H}-2,149$, to $8 \mathrm{H}-3,11$ & $64.90-65.02$ & 0.12 \\
\hline $8 \mathrm{H}-4,147$, to $8 \mathrm{H}-5,9$ & $67.80-67.91$ & 0.12 \\
\hline $8 \mathrm{H}-7,3-10$ & $70.77-70.83$ & 0.07 \\
\hline $9 \mathrm{H}-1,144$, to $9 \mathrm{H}-2,10$ & $72.86-73.02$ & 0.15 \\
\hline $9 \mathrm{H}-2,30-80$ & $73.20-73.68$ & 0.47 \\
\hline $9 \mathrm{H}-3,142$, to $9 \mathrm{H}-4,52$ & $75.69-76.25$ & 0.57 \\
\hline $9 \mathrm{H}-4,60-77$ & $76.33-76.49$ & 0.16 \\
\hline $9 \mathrm{H}-5,60$, to $9 \mathrm{H}-6,10$ & $77.75-78.70$ & 0.95 \\
\hline $10 \mathrm{H}-2,56-86$ & $82.98-83.27$ & 0.29 \\
\hline $10 \mathrm{H}-2,128-137$ & $83.67-83.76$ & 0.09 \\
\hline $10 \mathrm{H}-2,147$, to $10 \mathrm{H}-3,97$ & $83.86-84.82$ & 0.96 \\
\hline $10 \mathrm{H}-3,140-150$ & $85.23-85.33$ & 0.10 \\
\hline $10 \mathrm{H}-4,16-78$ & $85.48-86.08$ & 0.60 \\
\hline $10 \mathrm{H}-4,131$, to $10 \mathrm{H}-5,56$ & $86.59-87.31$ & 0.72 \\
\hline $10 \mathrm{H}-5,89$, to $10 \mathrm{H}-6,10$ & $87.63-88.31$ & 0.68 \\
\hline $10 \mathrm{H}-6,33-105$ & $88.53-89.22$ & 0.69 \\
\hline $10 \mathrm{H}-6,140-150$ & $89.56-89.65$ & 0.10 \\
\hline $10 \mathrm{H}-7,27$, to $11 \mathrm{H}-1,15$ & $89.91-90.65$ & 0.73 \\
\hline $11 \mathrm{H}-1,136$, to $11 \mathrm{H}-2,13$ & $91.82-92.08$ & 0.26 \\
\hline $11 \mathrm{H}-3,91-112$ & $94.30-94.50$ & 0.20 \\
\hline $11 \mathrm{H}-4,112-129$ & $95.96-96.12$ & 0.17 \\
\hline $11 \mathrm{H}-5,25-70$ & $96.57-97.00$ & 0.44 \\
\hline $11 \mathrm{H}-5,95$, to $11 \mathrm{H}-6,45$ & $97.25-98.22$ & 0.97 \\
\hline $11 \mathrm{H}-6,120$, to $12 \mathrm{H}-1,104$ & $98.46-100.99$ & 2.53 \\
\hline $12 \mathrm{H}-1,129$, to $12 \mathrm{H}-2,45$ & $101.22-101.85$ & 0.63 \\
\hline $12 \mathrm{H}-2,105$, to $12 \mathrm{H}-3,30$ & $102.42-103.13$ & 0.71 \\
\hline $12 \mathrm{H}-3,105$, to $12 \mathrm{H}-4,25$ & $103.84-104.52$ & 0.68 \\
\hline $12 \mathrm{H}-4,120$, to $12 \mathrm{H}-5,40$ & $105.40-106.07$ & 0.67 \\
\hline $12 \mathrm{H}-5,100$, to $13 \mathrm{H}-2,15$ & $106.64-111.07$ & 4.43 \\
\hline $13 \mathrm{H}-2,140$, to $13 \mathrm{H}-6,20$ & $112.26-116.83$ & 4.57 \\
\hline $13 \mathrm{H}-6,55-95$ & $117.17-117.55$ & 0.38 \\
\hline $13 \mathrm{H}-6,130$, to $13 \mathrm{H}-7,25$ & $117.88-118.31$ & 0.43 \\
\hline $13 \mathrm{H}-7,75$, to $14 \mathrm{H}-1,50$ & $118.79-119.48$ & 0.69 \\
\hline $14 \mathrm{H}-2,70$, to $15 \mathrm{H}-2,50$ & $121.12-130.50$ & 9.38 \\
\hline $15 \mathrm{H}-2,80$, to $15 \mathrm{H}-4,15$ & $130.80-133.15$ & 2.35 \\
\hline $15 \mathrm{H}-4,79-131$ & $133.79-134.31$ & 0.52 \\
\hline $15 \mathrm{H}-4,146$, to $15 \mathrm{H}-5,62$ & $134.46-135.12$ & 0.66 \\
\hline $15 \mathrm{H}-5,83-103$ & $135.33-135.53$ & 0.20 \\
\hline $17 \mathrm{H}-3,5-12$ & $141.99-142.06$ & 0.07 \\
\hline $17 \mathrm{H}-3,135$, to $17 \mathrm{H}-5,12$ & $143.26-145.00$ & 1.74 \\
\hline $17 \mathrm{H}-5,25-55$ & $145.13-145.42$ & 0.29 \\
\hline $17 \mathrm{H}-6,40-70$ & $146.75-147.04$ & 0.29 \\
\hline $17 \mathrm{H}-6,125$, to $17 \mathrm{H}-7,12$ & $147.58-147.94$ & 0.36 \\
\hline
\end{tabular}

Appendix Table 1 (continued).

\begin{tabular}{|c|c|c|}
\hline $\begin{array}{l}\text { Core, section, } \\
\text { interval }(\mathrm{cm})\end{array}$ & $\begin{array}{l}\text { Depth } \\
\text { (mbsf) }\end{array}$ & $\begin{array}{c}\text { Thickness } \\
\text { (m) }\end{array}$ \\
\hline \multicolumn{3}{|l|}{ 119-745B-(Cont.) } \\
\hline $17 \mathrm{H}-7,40$, to $18 \mathrm{H}-1,32$ & $148.22-148.81$ & 0.59 \\
\hline $18 \mathrm{H}-1,123$, to $18 \mathrm{H}-3,20$ & $149.68-151.58$ & 1.89 \\
\hline $18 \mathrm{H}-4,57-64$ & $153.38-153.44$ & 0.07 \\
\hline $18 \mathrm{H}-4,120$, to $18 \mathrm{H}-5,15$ & $153.98-154.41$ & 0.43 \\
\hline $18 \mathrm{H}-5,26-57$ & $154.52-154.82$ & 0.30 \\
\hline $18 \mathrm{H}-5,75$, to $18 \mathrm{H}-6,50$ & 154.99-156.19 & 1.20 \\
\hline $18 \mathrm{H}-6,110$, to $19 \mathrm{H}-1,130$ & $156.77-159.23$ & 2.46 \\
\hline $19 \mathrm{H}-2,82$, to $19 \mathrm{H}-3,17$ & $160.20-161.01$ & 0.81 \\
\hline $19 \mathrm{H}-3,60$, to $19 \mathrm{H}-4,15$ & $161.42-162.42$ & 1.00 \\
\hline $19 \mathrm{H}-4,40$, to $19 \mathrm{H}-5,50$ & $162.65-164.17$ & 1.52 \\
\hline $19 \mathrm{H}-5,62$, to $19 \mathrm{H}-6,40$ & $164.29-165.50$ & 1.22 \\
\hline $19 \mathrm{H}-6,60-80$ & $165.69-165.88$ & 0.19 \\
\hline $19 \mathrm{H}-6,120$, to $19 \mathrm{H}-7,20$ & $166.26-166.74$ & 0.48 \\
\hline $20 \mathrm{H}-2,7-12$ & $169.01-169.06$ & 0.05 \\
\hline $20 \mathrm{H}-2,70$, to $20 \mathrm{H}-3,80$ & $169.62-171.15$ & 1.53 \\
\hline $20 \mathrm{H}-3,105$, to $20 \mathrm{H}-4,15$ & $171.39-171.97$ & 0.58 \\
\hline $20 \mathrm{H}-4,60$, to $20 \mathrm{H}-5,95$ & $172.40-174.18$ & 1.78 \\
\hline $20 \mathrm{H}-5,107$, to $20 \mathrm{H}-6,20$ & $174.30-174.90$ & 0.61 \\
\hline $20 \mathrm{H}-6,75-115$ & $175.43-175.82$ & 0.38 \\
\hline $20 \mathrm{H}-6,145$, to $21 \mathrm{H}-3,75$ & $176.11-180.55$ & 4.45 \\
\hline $21 \mathrm{H}-4,7-14$ & $181.33-181.39$ & 0.07 \\
\hline $21 \mathrm{H}-4,106$, to $21 \mathrm{H}-6,20$ & $182.27-184.29$ & 2.03 \\
\hline $21 \mathrm{H}-6,52-90$ & $184.59-184.95$ & 0.36 \\
\hline $21 \mathrm{H}-6,110$, to $21 \mathrm{H}-7,12$ & $185.14-185.64$ & 0.49 \\
\hline $21 \mathrm{H}-7,50-63$ & $186.00-186.12$ & 0.12 \\
\hline $21 \mathrm{H}-\mathrm{CC}, 13$, to $22 \mathrm{H}-1,43$ & $186.38-186.93$ & 0.55 \\
\hline $22 \mathrm{H}-1,120$, to $22 \mathrm{H}-2,140$ & $187.70-189.40$ & 1.70 \\
\hline $22 \mathrm{H}-3,7-15$ & $189.57-189.65$ & 0.08 \\
\hline $22 \mathrm{H}-3,60-125$ & $190.10-190.75$ & 0.65 \\
\hline $22 \mathrm{H}-4,10-20$ & $191.10-191.20$ & 0.10 \\
\hline $22 \mathrm{H}-5,0-15$ & $192.50-192.65$ & 0.15 \\
\hline $22 \mathrm{H}-5,63$, to $22 \mathrm{H}-6,57$ & $193.13-194.57$ & 1.44 \\
\hline $22 \mathrm{H}-6,130$, to $22 \mathrm{H}-7,16$ & $195.30-195.66$ & 0.36 \\
\hline $23 \mathrm{H}-1,0-60$ & $196.00-196.57$ & 0.57 \\
\hline $23 \mathrm{H}-1,80-115$ & $196.76-197.10$ & 0.33 \\
\hline $23 \mathrm{H}-2,53-98$ & 197.93-198.36 & 0.43 \\
\hline $23 \mathrm{H}-3,29-82$ & 199.13-199.64 & 0.50 \\
\hline $23 \mathrm{H}-3,133$, to $23 \mathrm{H}-4,16$ & $200.12-200.44$ & 0.31 \\
\hline $23 \mathrm{H}-4,36$, to $23 \mathrm{H}-5,22$ & $200.63-201.92$ & 1.30 \\
\hline $23 \mathrm{H}-5,77-88$ & $202.45-202.55$ & 0.10 \\
\hline $23 \mathrm{H}-7,32$, to $24 \mathrm{H}-1,44$ & $204.88-205.92$ & 1.04 \\
\hline $24 \mathrm{H}-1,99$, to $24 \mathrm{H}-2,45$ & 206.43-207.34 & 0.91 \\
\hline $24 \mathrm{H}-2,130$, to $24 \mathrm{H}-3,15$ & 208.14-208.47 & 0.33 \\
\hline $24 \mathrm{H}-3,46-135$ & 208.77-209.61 & 0.84 \\
\hline $24 \mathrm{H}-4,10-30$ & $209.84-210.03$ & 0.19 \\
\hline $24 \mathrm{H}-4,75$, to $24 \mathrm{H}-5,30$ & $210.46-211.45$ & 0.99 \\
\hline $24 \mathrm{H}-5,56-82$ & $211.69-211.94$ & 0.25 \\
\hline $24 \mathrm{H}-5,106$, to $24 \mathrm{H}-6,95$ & $212.17-213.48$ & 1.31 \\
\hline $24 \mathrm{H}-7,7-15$ & $214.06-214.14$ & 0.08 \\
\hline
\end{tabular}

119-746A-

$4 \mathrm{H}-1,135$, to $4 \mathrm{H}-2,27$

$166.10-166.50$ 166.69-167.07

$4 \mathrm{H}-2,47-86$

$4 \mathrm{H}-2,103-120$

$4 \mathrm{H}-2,126$, to $4 \mathrm{H}-3,25$

$4 \mathrm{H}-3,46-59$

$4 \mathrm{H}-3,115-141$

$4 \mathrm{H}-4,40-55$

$4 \mathrm{H}-4,105-120$

$4 \mathrm{H}-5,8-38$

$4 \mathrm{H}-5,77-150$

$4 \mathrm{H}-6,30-40$

$4 \mathrm{H}-6,61-80$

$4 \mathrm{H}-6,90-119$

$4 \mathrm{H}-7,21$, to $5 \mathrm{H}-2,13$

$5 \mathrm{H}-2,125$, to $5 \mathrm{H}-3,40$

$5 \mathrm{H}-3,65$, to $5 \mathrm{H}-6,42$

$5 \mathrm{H}-6,100$, to $5 \mathrm{H}-7,15$

$5 \mathrm{H}-7,35-50$

$5 \mathrm{H}-7,60-70$

$6 \mathrm{H}-1,0$, to $6 \mathrm{H}-2,130$

$6 \mathrm{H}-4,45$, to $6 \mathrm{H}-5,20$

$6 \mathrm{H}-5,125$, to $6 \mathrm{H}-6,10$

$6 \mathrm{H}-6,87$, to $6 \mathrm{H}-\mathrm{CC}, 14$

$7 \mathrm{H}-1,105$, to $7 \mathrm{H}-2,10$

$7 \mathrm{H}-3,100$, to $7 \mathrm{H}-4,90$
$67.23-167.40-0.16$

167.45-167.93 $\quad 0.47$

$168.13-168.25 \quad 0.13$

168.79-169.04 $\quad 0.25$

169.51-169.66 0.14

$170.14-170.28 \quad 0.14$

$\begin{array}{ll}170.65-170.93 & 0.29\end{array}$

$171.31-172.01 \quad 0.70$

$172.30-172.40 \quad 0.10$

$\begin{array}{ll}172.60-172.78 & 0.18\end{array}$

$\begin{array}{ll}172.88-173.16 & 0.28\end{array}$

173.66-175.84 2.19

$176.90-177.52 \quad 0.62$

177.76-181.80 4.04

$182.35-182.96-0.62$

$183.15-183.30 \quad 0.14$

183.39-183.49 $\quad 0.09$

$\begin{array}{ll}183.80-186.55 & 2.75\end{array}$

188.65-189.88 $\quad 1.23$

190.91-191.25 $\quad 0.34$

192.01-193.28 $\quad 1.27$

194.32-194.85 $\quad 0.53$

$\begin{array}{ll}197.18-198.54 & 1.36\end{array}$ 
Appendix Table 1 (continued).

\begin{tabular}{|c|c|c|}
\hline $\begin{array}{l}\text { Core, section, } \\
\text { interval }(\mathrm{cm})\end{array}$ & $\begin{array}{l}\text { Depth } \\
\text { (mbsf) }\end{array}$ & $\begin{array}{l}\text { Thickness } \\
\text { (m) }\end{array}$ \\
\hline \multicolumn{3}{|l|}{ 119-746A-(Cont.) } \\
\hline $7 \mathrm{H}-5,120$, to $7 \mathrm{H}-6,55$ & $200.29-201.12$ & 0.83 \\
\hline $7 \mathrm{H}-6,145$, to $8 \mathrm{H}-1,40$ & $201.99-203.20$ & 1.21 \\
\hline $8 \mathrm{H}-3,140$, to $8 \mathrm{H}-4,15$ & $207.20-207.45$ & 0.25 \\
\hline $8 \mathrm{H}-5,130$, to $9 \mathrm{H}-1,23$ & $208.75-209.53$ & 0.78 \\
\hline Disturbed interval & $209.90-214.10$ & \\
\hline $9 \mathrm{H}-4,30-130$ & $214.10-215.10$ & 1.00 \\
\hline $9 \mathrm{H}-5,40$, to $9 \mathrm{H}-6,62$ & $215.70-217.42$ & 1.72 \\
\hline $10 \mathrm{H}-1,0$, to $10 \mathrm{H}-3,70$ & $217.80-221.36$ & 3.56 \\
\hline $10 \mathrm{H}-3,97$, to $10 \mathrm{H}-4,20$ & $221.62-222.32$ & 0.70 \\
\hline $10 \mathrm{H}-4,130$, to $10 \mathrm{H}-5,77$ & $223.38-224.31$ & 0.93 \\
\hline $10 \mathrm{H}-5,132$, to $10 \mathrm{H}-6,35$ & $224.84-225.35$ & 0.51 \\
\hline $10 \mathrm{H}-6,87$, to $11 \mathrm{X}-2,35$ & $225.85-228.73$ & 2.88 \\
\hline $11 \mathrm{X}-2,100$, to $11 \mathrm{X}-3,12$ & $229.24-229.72$ & 0.48 \\
\hline $11 X-3,115$, to $11 X-4,107$ & $230.52-231.62$ & 1.10 \\
\hline $11 \mathrm{X}-4,123$, to $11 \mathrm{X}-\mathrm{CC}$ & $231.74-234.80$ & 3.06 \\
\hline No recovery & $234.80-242.20$ & \\
\hline $13 X-1,140$, to $13 X-2,35$ & $243.57-244.01$ & 0.44 \\
\hline $13 \mathrm{X}-2,127$, to $13 \mathrm{X}-3,150$ & $244.43-246.61$ & 2.18 \\
\hline Nannofossil ooze & $246.61-247.18$ & \\
\hline $13 X-4,58-95$ & $247.18-247.54$ & 0.36 \\
\hline $13 X-5,45$, to $13 X-6,30$ & $248.52-249.85$ & 1.33 \\
\hline $13 X-6,140$, to $14 X-1,70$ & $250.93-252.50$ & 1.57 \\
\hline $14 X-2,0-15$ & $253.30-253.45$ & 0.15 \\
\hline No recovery & $253.68-261.50$ & \\
\hline $15 \mathrm{X}-1,0$, to $15 \mathrm{X}-\mathrm{CC}$, & $261.50-262.57$ & 1.07 \\
\hline No recovery & $262.57-271.10$ & \\
\hline $16 \mathrm{X}-1,0$, to $16 \mathrm{X}-\mathrm{CC}$, & $271.10-272.40$ & 1.30 \\
\hline
\end{tabular}


Appendix Table 2. Sediment composition at ODP Sites $\mathbf{7 4 5}$ and $\mathbf{7 4 6}$. All data are given in weight percent, except for the quartz/feldspar ratio, which is calculated from XRD peak areas. Sample depths are corrected for recovery $>100 \%$.

\begin{tabular}{|c|c|c|c|c|c|c|c|}
\hline $\begin{array}{l}\text { Core, section, } \\
\text { interval }(\mathrm{cm})\end{array}$ & $\begin{array}{l}\text { Depth } \\
\text { (mbsf) }\end{array}$ & $\begin{array}{l}\text { Opal } \\
(\%)\end{array}$ & $\begin{array}{c}\text { Terrigenous } \\
\text { material } \\
(\%)\end{array}$ & $\begin{array}{c}\text { Organic } \\
\text { carbon } \\
(\%)\end{array}$ & $\begin{array}{c}\text { Carbonate } \\
(\%)\end{array}$ & $\begin{array}{c}\text { Quartz } \\
(\%)\end{array}$ & $\begin{array}{l}\text { Quartz/ } \\
\text { feldspar }\end{array}$ \\
\hline \multicolumn{8}{|l|}{$119-745 \mathrm{~B}-$} \\
\hline $1 \mathrm{H}-1,48-50$ & 0.47 & 61.4 & 38.6 & 0.24 & 0.35 & 2.7 & 1.5 \\
\hline $1 \mathrm{H}-3,48-50$ & 3.41 & 30.7 & 69.3 & 0.27 & 0.46 & & \\
\hline $1 \mathrm{H}-4,20-22$ & 4.61 & 34.8 & 65.2 & 0.27 & 0.32 & & \\
\hline $2 \mathrm{H}-1,48-50$ & 5.47 & 58.1 & 41.9 & 0.16 & 0.32 & & \\
\hline $2 \mathrm{H}-2,48-50$ & 6.92 & 49.6 & 50.5 & 0.11 & 0.74 & 6.0 & 2.3 \\
\hline $2 \mathrm{H}-3,48-50$ & 8.38 & 54.6 & 45.4 & 0.23 & 0.47 & & \\
\hline $2 \mathrm{H}-4,48-50$ & 9.83 & 62.8 & 37.2 & 0.27 & 0.42 & & \\
\hline $2 \mathrm{H}-5,48-50$ & 11.29 & 65.5 & 34.5 & 0.18 & 0.29 & & \\
\hline $2 \mathrm{H}-6,48-50$ & 12.75 & 63.3 & 36.7 & 0.04 & 1.42 & 3.3 & 2.1 \\
\hline $2 \mathrm{H}-7,48-50$ & 14.20 & 42.6 & 57.4 & 0.30 & 0.36 & & \\
\hline $3 \mathrm{H}-1,48-50$ & 14.98 & 63.6 & 36.4 & 0.19 & 0.32 & & \\
\hline $3 \mathrm{H}-2,48-50$ & 16.48 & 57.6 & 42.4 & 0.18 & 0.37 & 3.8 & 1.3 \\
\hline $3 \mathrm{H}-3,48-50$ & 17.98 & 57.8 & 42.2 & 0.34 & 0.73 & & \\
\hline $3 \mathrm{H}-4,48-50$ & 19.48 & 55.4 & 44.6 & 0.31 & 0.46 & & \\
\hline $3 \mathrm{H}-5,48-50$ & 20.98 & 57.0 & 43.0 & 0.30 & 0.21 & & \\
\hline $3 \mathrm{H}-6,49-52$ & 22.49 & 48.3 & 51.7 & 0.18 & 0.26 & & \\
\hline $4 \mathrm{H}-1,50-52$ & 24.48 & 61.6 & 38.4 & 0.26 & 0.37 & & \\
\hline $4 \mathrm{H}-2,50-52$ & 25.94 & 38.4 & 61.6 & 0.13 & 0.35 & & \\
\hline $4 \mathrm{H}-3,50-52$ & 27.40 & 26.2 & 73.8 & 0.28 & 0.12 & 7.6 & 1.6 \\
\hline $4 \mathrm{H}-4,50-52$ & 28.85 & 60.6 & 39.4 & 0.21 & 0.26 & & \\
\hline $4 \mathrm{H}-5,50-52$ & 30.31 & 61.8 & 37.2 & 0.20 & 0.36 & & \\
\hline $4 \mathrm{H}-6,50-52$ & 31.77 & 60.0 & 40.0 & & & & \\
\hline $4 \mathrm{H}-7,50-52$ & 33.22 & 18.7 & 81.3 & 0.22 & 0.42 & 7.7 & 1.8 \\
\hline $5 \mathrm{H}-1,48-50$ & 33.97 & 47.3 & 52.7 & 0.20 & 0.26 & & \\
\hline $5 \mathrm{H}-2,48-50$ & 35.42 & 54.3 & 45.7 & 0.21 & 0.37 & & \\
\hline $5 \mathrm{H}-3,48-50$ & 36.88 & 40.2 & 59.9 & 0.19 & 0.32 & & \\
\hline $5 \mathrm{H}-4,48-50$ & 38.33 & 39.4 & 60.7 & 0.29 & 0.37 & 5.5 & 1.3 \\
\hline $5 \mathrm{H}-5,48-50$ & 39.79 & 25.7 & 74.3 & 0.27 & 0.27 & & \\
\hline $5 \mathrm{H}-6,48-50$ & 41.25 & 23.4 & 76.6 & 0.20 & 0.35 & & \\
\hline $5 \mathrm{H}-7,48-50$ & 42.70 & 41.0 & 59.0 & 0.28 & 0.28 & & \\
\hline $6 \mathrm{H}-1,48-50$ & 43.48 & 30.2 & 69.8 & 0.16 & 0.15 & 9.7 & 2.2 \\
\hline $6 \mathrm{H}-2,48-50$ & 44.98 & 20.7 & 79.3 & 0.18 & 0.26 & & \\
\hline $6 \mathrm{H}-3,48-50$ & 46.48 & 12.1 & 87.9 & 0.21 & 0.45 & & \\
\hline $6 \mathrm{H}-4,48-50$ & 47.98 & & & 0.15 & 0.32 & & \\
\hline $6 \mathrm{H}-5,43-45$ & 49.43 & 44.4 & 55.6 & 0.12 & 0.41 & & \\
\hline $6 \mathrm{H}-6,48-50$ & 50.98 & 49.4 & 50.6 & 0.16 & 0.33 & 7.1 & 2.2 \\
\hline $7 \mathrm{H}-1,48-50$ & 52.97 & 41.3 & 58.7 & 0.13 & 0.34 & & \\
\hline $7 \mathrm{H}-2,48-50$ & 54.42 & 16.5 & 83.5 & 0.20 & 0.92 & 11.4 & 2.2 \\
\hline $7 \mathrm{H}-3,48-50$ & 55.88 & 13.0 & 87.0 & 0.20 & 0.42 & 7.4 & 1.9 \\
\hline $7 \mathrm{H}-4,48-50$ & 57.33 & 63.8 & 36.2 & 0.17 & 0.36 & 7.7 & 2.3 \\
\hline $7 \mathrm{H}-5,48-50$ & 58.79 & 39.2 & 60.8 & 0.12 & 0.57 & 6.2 & 1.4 \\
\hline $7 \mathrm{H}-6,48-50$ & 60.25 & 55.0 & 45.1 & 0.16 & 0.32 & & \\
\hline $7 \mathrm{H}-7,48-50$ & 61.70 & 42.8 & 57.2 & 0.14 & 0.28 & & \\
\hline $8 \mathrm{H}-1,48-50$ & 62.47 & 39.4 & 60.6 & 0.21 & 0.25 & & \\
\hline $8 \mathrm{H}-2,48-50$ & 63.92 & 22.5 & 77.5 & 0.31 & 0.18 & 7.5 & 2.0 \\
\hline $8 \mathrm{H}-3,48-50$ & 65.38 & 47.8 & 52.2 & 0.18 & 0.32 & & \\
\hline $8 \mathrm{H}-4,48-50$ & 66.83 & 66.9 & 33.1 & 0.22 & 0.23 & & \\
\hline $8 \mathrm{H}-5,48-50$ & 68.29 & 47.0 & 53.0 & 0.13 & 0.43 & & \\
\hline $8 \mathrm{H}-6,48-50$ & 69.75 & 38.8 & 61.2 & 0.15 & 0.57 & 5.4 & 1.6 \\
\hline $8 \mathrm{H}-7,48-50$ & 71.20 & 51.8 & 48.2 & 0.14 & 0.33 & & \\
\hline $9 \mathrm{H}-1,48-50$ & 71.95 & 77.5 & 22.6 & 0.17 & 0.15 & & \\
\hline $9 \mathrm{H}-2,48-50$ & 73.38 & 16.3 & 83.7 & 0.15 & 0.39 & & \\
\hline $9 \mathrm{H}-3,48-50$ & 74.80 & 78.1 & 21.9 & 0.18 & 0.29 & 2.4 & 1.3 \\
\hline $9 \mathrm{H}-4,48-50$ & 76.22 & 21.2 & 78.8 & 0.15 & 0.40 & & \\
\hline $9 \mathrm{H}-5,48-50$ & 77.64 & 60.9 & 39.1 & 0.16 & 0.50 & & \\
\hline $9 \mathrm{H}-6,48-50$ & 79.06 & 55.3 & 44.7 & 0.23 & 0.40 & & \\
\hline $9 \mathrm{H}-7,48-50$ & 80.48 & 59.3 & 40.7 & 0.14 & 0.47 & 4.0 & 1.4 \\
\hline $10 \mathrm{H}-1,48-50$ & 81.46 & 47.0 & 53.0 & 0.19 & 0.45 & & \\
\hline $10 \mathrm{H}-2,48-50$ & 82.90 & 42.1 & 57.9 & 0.16 & 0.50 & & \\
\hline $10 \mathrm{H}-3,48-50$ & 84.35 & 24.3 & 75.7 & 0.16 & 0.47 & & \\
\hline $10 \mathrm{H}-4,48-50$ & 85.79 & 33.7 & 66.3 & 0.12 & 0.57 & & \\
\hline $10 \mathrm{H}-5,48-50$ & 87.23 & 40.9 & 59.1 & 0.18 & 0.40 & 7.7 & 2.5 \\
\hline $10 \mathrm{H}-6,48-50$ & 88.67 & 29.7 & 70.3 & 0.13 & 0.44 & & \\
\hline $10 \mathrm{H}-7,48-50$ & 90.12 & 56.8 & 43.2 & 0.11 & 0.32 & & \\
\hline $11 \mathrm{H}-1,48-50$ & 90.97 & 32.0 & 68.0 & 0.23 & 0.36 & & \\
\hline $11 \mathrm{H}-2,48-50$ & 92.42 & 58.2 & 41.8 & 0.14 & 0.57 & 4.8 & 1.5 \\
\hline $11 \mathrm{H}-3,48-50$ & 93.88 & 79.9 & 20.1 & 0.19 & 0.37 & & \\
\hline $11 \mathrm{H}-4,48-50$ & 95.33 & 86.4 & 13.6 & 0.18 & 0.22 & & \\
\hline $11 \mathrm{H}-5,48-50$ & 96.79 & 26.1 & 73.9 & 0.12 & 0.53 & & \\
\hline $11 \mathrm{H}-6,48-50$ & 98.25 & 33.3 & 66.7 & 0.10 & 0.49 & & \\
\hline $12 \mathrm{H}-1,48-50$ & 100.45 & 16.6 & 83.4 & 0.07 & 1.35 & 8.2 & 2.5 \\
\hline $12 \mathrm{H}-2,48-50$ & 101.88 & 25.0 & 75.0 & 0.25 & 0.62 & & \\
\hline $12 \mathrm{H}-3,48-50$ & 103.30 & 34.7 & 64.9 & 0.11 & 0.47 & & \\
\hline
\end{tabular}


Appendix Table 2 (continued).

\begin{tabular}{|c|c|c|c|c|c|c|c|}
\hline $\begin{array}{l}\text { Core, section, } \\
\text { interval }(\mathrm{cm})\end{array}$ & $\begin{array}{l}\text { Depth } \\
\text { (mbsf) }\end{array}$ & $\begin{array}{l}\text { Opal } \\
(\%)\end{array}$ & $\begin{array}{c}\text { Terrigenous } \\
\text { material } \\
(\%)\end{array}$ & $\begin{array}{c}\text { Organic } \\
\text { carbon } \\
(\%)\end{array}$ & $\begin{array}{c}\text { Carbonate } \\
(\%)\end{array}$ & $\begin{array}{c}\text { Quartz } \\
(\%)\end{array}$ & $\begin{array}{l}\text { Quartz/ } \\
\text { feldspar }\end{array}$ \\
\hline \multicolumn{8}{|l|}{ 119-745B-(Cont.) } \\
\hline $12 \mathrm{H}-4,48-50$ & 104.72 & 44.7 & 55.4 & 0.14 & 0.57 & & \\
\hline $12 \mathrm{H}-5,48-50$ & 106.14 & 37.5 & 62.5 & 0.16 & 0.41 & 5.9 & 1.2 \\
\hline $12 \mathrm{H}-6,48-50$ & 107.56 & 20.5 & 79.5 & 0.16 & 0.33 & & \\
\hline $12 \mathrm{H}-7,48-50$ & 108.98 & 10.6 & 89.4 & 0.22 & 0.34 & & \\
\hline $13 \mathrm{H}-1,48-50$ & 109.96 & 19.3 & 80.7 & 0.25 & 0.35 & & \\
\hline $13 \mathrm{H}-2,48-50$ & 111.39 & 38.4 & 61.6 & 0.12 & 0.77 & 8.1 & 1.7 \\
\hline $13 \mathrm{H}-3,48-50$ & 112.81 & 20.5 & 79.5 & 0.16 & 0.32 & & \\
\hline $13 \mathrm{H}-4,48-50$ & 114.24 & 23.9 & 76.1 & 0.18 & 0.41 & & \\
\hline $13 \mathrm{H}-5,48-50$ & 115.67 & 11.5 & 88.5 & 0.15 & 0.33 & & \\
\hline $13 \mathrm{H}-6,48-50$ & 117.10 & 33.9 & 66.1 & 0.17 & 0.32 & & \\
\hline $13 \mathrm{H}-7,48-50$ & 118.53 & 51.4 & 49.8 & & & 5.9 & 1.4 \\
\hline $14 \mathrm{H}-1,48-50$ & 119.46 & 23.3 & 76.7 & 0.13 & 0.36 & & \\
\hline $14 \mathrm{H}-2,48-50$ & 120.90 & 16.9 & 83.1 & 0.17 & 0.27 & & \\
\hline $14 \mathrm{H}-3,48-50$ & 122.35 & 15.9 & 84.1 & 0.18 & 0.53 & & \\
\hline $14 \mathrm{H}-4,48-50$ & 123.79 & 8.8 & 91.2 & 0.12 & 0.32 & & \\
\hline $14 \mathrm{H}-5,48-50$ & 125.23 & 17.2 & 82.8 & 0.14 & 0.49 & 11.5 & 2.5 \\
\hline $14 \mathrm{H}-6,48-50$ & 126.67 & 28.3 & 71.7 & 0.11 & 0.22 & & \\
\hline $14 \mathrm{H}-7,48-50$ & 128.12 & 16.4 & 83.6 & 0.11 & 0.24 & & \\
\hline $15 \mathrm{H}-1,48-50$ & 128.98 & 20.7 & 79.3 & 0.13 & 0.38 & & \\
\hline $15 \mathrm{H}-2,48-50$ & 130.48 & 22.6 & 77.4 & 0.13 & 0.29 & 11.2 & 2.1 \\
\hline $15 \mathrm{H}-3,48-50$ & 131.98 & 19.0 & 81.0 & 0.12 & 0.21 & & \\
\hline $15 \mathrm{H}-4,48-50$ & 133.48 & 37.9 & 62.1 & 0.10 & 0.32 & & \\
\hline $15 \mathrm{H}-5,48-50$ & 134.98 & 25.7 & 74.3 & 0.09 & 0.22 & & \\
\hline $15 \mathrm{H}-6,48-50$ & 136.48 & 38.2 & 61.8 & 0.08 & 0.50 & 10.3 & 2.7 \\
\hline $17 \mathrm{H}-1,48-50$ & 139.47 & 32.0 & 68.0 & 0.13 & 0.29 & & \\
\hline $17 \mathrm{H}-2,48-50$ & 140.94 & 51.6 & 48.4 & 0.13 & 0.26 & & \\
\hline $17 \mathrm{H}-3,48-50$ & 142.41 & 38.7 & 61.3 & 0.09 & 0.31 & & \\
\hline $17 \mathrm{H}-4,48-50$ & 143.88 & 37.5 & 62.5 & 0.12 & 0.31 & & \\
\hline $17 \mathrm{H}-5,48-50$ & 145.35 & 37.8 & 62.3 & 0.11 & 0.19 & 12.0 & 2.9 \\
\hline $17 \mathrm{H}-6,48-50$ & 146.82 & 22.5 & 77.5 & 0.09 & 0.26 & & \\
\hline $17 \mathrm{H}-7,46-48$ & 148.27 & 32.5 & 67.5 & 0.10 & 0.27 & & \\
\hline $18 \mathrm{H}-1,44-46$ & 148.92 & 27.7 & 72.3 & 0.11 & 0.32 & & \\
\hline $18 \mathrm{H}-2,44-46$ & 150.37 & 27.6 & 72.4 & 0.13 & 0.23 & 9.4 & 2.5 \\
\hline $18 \mathrm{H}-3,44-46$ & 151.81 & & & 0.19 & 0.24 & & \\
\hline $18 \mathrm{H}-4,44-46$ & 153.25 & 45.9 & 54.1 & 0.12 & 0.29 & & \\
\hline $18 \mathrm{H}-5,44-46$ & 154.69 & 29.9 & 70.1 & 0.12 & 0.22 & & \\
\hline $18 \mathrm{H}-6,44-46$ & 156.13 & 29.0 & 71.0 & 0.12 & 0.27 & 7.0 & 1.8 \\
\hline $18 \mathrm{H}-7,44-46$ & 157.58 & 38.4 & 61.6 & 0.09 & 0.48 & & \\
\hline $19 \mathrm{H}-1,40-42$ & 158.38 & 31.0 & 69.0 & 0.22 & 0.72 & & \\
\hline $19 \mathrm{H}-2,40-42$ & 159.80 & 40.7 & 59.3 & 0.16 & 0.50 & & \\
\hline $19 \mathrm{H}-3,40-42$ & 161.23 & & & 0.12 & 0.42 & 8.4 & 1.6 \\
\hline $19 \mathrm{H}-4,40-42$ & 162.69 & 34.0 & 66.0 & 0.13 & 0.31 & & \\
\hline $19 \mathrm{H}-5,40-42$ & 164.08 & 26.1 & 73.9 & 0.18 & 0.33 & & \\
\hline $19 \mathrm{H}-6,40-42$ & 165.50 & 44.2 & 55.9 & 0.14 & 0.45 & & \\
\hline $19 \mathrm{H}-7,40-42$ & 166.93 & 27.2 & 72.8 & 0.14 & 0.43 & 13.1 & 2.9 \\
\hline $20 \mathrm{H}-1,52-54$ & 168.00 & 42.4 & 57.7 & 0.11 & 0.26 & & \\
\hline $20 \mathrm{H}-2,47-49$ & 169.39 & 26.4 & 73.6 & 0.12 & 0.22 & & \\
\hline $20 \mathrm{H}-3,47-49$ & 170.84 & 23.6 & 76.5 & 0.16 & 0.27 & & \\
\hline $20 \mathrm{H}-4,47-49$ & 172.28 & 51.3 & 48.7 & 0.14 & 0.38 & 6.9 & 2.0 \\
\hline $20 \mathrm{H}-5,47-49$ & 173.72 & 27.3 & 72.7 & 0.21 & 0.27 & & \\
\hline $20 \mathrm{H}-6,47-49$ & 175.16 & 33.4 & 66.6 & 0.18 & 0.52 & & \\
\hline $20 \mathrm{H}-7,47-49$ & 176.61 & 21.4 & 78.6 & 0.30 & 0.34 & & \\
\hline $21 \mathrm{H}-2,48-50$ & 178.88 & 25.6 & 74.4 & 0.20 & 0.24 & 9.8 & 2.7 \\
\hline $21 \mathrm{H}-3,48-50$ & 180.30 & 26.9 & 73.1 & 0.20 & 0.35 & & \\
\hline $21 \mathrm{H}-4,48-50$ & 181.72 & 40.1 & 59.9 & 0.16 & 0.33 & & \\
\hline $21 \mathrm{H}-5,48-50$ & 183.14 & 48.2 & 51.8 & 0.25 & 0.27 & & \\
\hline $21 \mathrm{H}-6,48-50$ & 184.56 & 29.2 & 70.8 & 0.19 & 0.27 & 8.9 & 2.0 \\
\hline $21 \mathrm{H}-7,48-50$ & 185.98 & 36.7 & 63.3 & 0.20 & 0.26 & & \\
\hline $22 \mathrm{H}-1,48-50$ & 186.98 & 36.7 & 63.3 & 0.22 & 0.30 & & \\
\hline $22 \mathrm{H}-2,48-50$ & 188.48 & 50.4 & 49.6 & 0.18 & 0.27 & & \\
\hline $22 \mathrm{H}-3,48-50$ & 189.98 & 36.1 & 63.9 & 0.17 & 0.22 & 11.6 & 2.5 \\
\hline $22 \mathrm{H}-4,48-50$ & 191.48 & 33.9 & 66.1 & 0.19 & 0.31 & & \\
\hline $22 \mathrm{H}-5,48-50$ & 192.98 & 37.2 & 62.8 & 0.19 & 0.26 & & \\
\hline $22 \mathrm{H}-6,48-50$ & 194.48 & 29.3 & 70.8 & 0.30 & 0.28 & & \\
\hline $23 \mathrm{H}-1,48-50$ & 196.46 & 34.9 & 65.1 & 0.19 & 0.35 & & \\
\hline $23 \mathrm{H}-2,48-50$ & 197.89 & 44.9 & 55.1 & 0.17 & 0.18 & 8.8 & 3.8 \\
\hline $23 \mathrm{H}-3,48-50$ & 199.31 & 29.3 & 70.7 & 0.17 & 0.24 & & \\
\hline $23 \mathrm{H}-4,48-50$ & 200.74 & 44.0 & 55.9 & 0.18 & 0.32 & & \\
\hline $23 \mathrm{H}-5,48-50$ & 202.17 & 39.8 & 60.2 & 0.10 & 0.51 & & \\
\hline $23 \mathrm{H}-6,48-50$ & 203.60 & 48.2 & 51.8 & 0.19 & 0.28 & 6.0 & 1.7 \\
\hline $23 \mathrm{H}-7,48-50$ & 205.03 & 34.7 & 65.4 & 0.20 & 0.32 & & \\
\hline $24 \mathrm{H}-1,48-50$ & 205.95 & 46.0 & 54.0 & 0.16 & 0.23 & & \\
\hline $24 \mathrm{H}-2,48-50$ & 207.37 & 36.1 & 63.9 & 0.20 & 0.29 & & \\
\hline $24 \mathrm{H}-3,48-50$ & 208.79 & 26.4 & 73.6 & 0.16 & 0.31 & & \\
\hline $24 \mathrm{H}-4,48-50$ & 210.11 & 40.2 & 59.8 & 0.18 & 0.29 & 10.0 & 2.4 \\
\hline $24 \mathrm{H}-5,48-50$ & 211.62 & 57.3 & 42.7 & 0.24 & 0.26 & & \\
\hline
\end{tabular}


Appendix Table 2 (continued).

\begin{tabular}{|c|c|c|c|c|c|c|c|}
\hline $\begin{array}{l}\text { Core, section, } \\
\text { interval }(\mathrm{cm})\end{array}$ & $\begin{array}{l}\text { Depth } \\
\text { (mbsf) }\end{array}$ & $\begin{array}{l}\text { Opal } \\
(\%)\end{array}$ & $\begin{array}{c}\text { Terrigenous } \\
\text { material } \\
(\%)\end{array}$ & $\begin{array}{c}\text { Organic } \\
\text { carbon } \\
(\%)\end{array}$ & $\begin{array}{c}\text { Carbonate } \\
(\%)\end{array}$ & $\begin{array}{c}\text { Quartz } \\
(\%)\end{array}$ & $\begin{array}{l}\text { Quartz/ } \\
\text { feldspar }\end{array}$ \\
\hline \multicolumn{8}{|l|}{ 119-745B-(Cont.) } \\
\hline $24 \mathrm{H}-6,48-50$ & 213.04 & 33.6 & 66.4 & 0.27 & 0.29 & & \\
\hline $24 \mathrm{H}-7,48-50$ & 214.45 & 38.4 & 61.6 & 0.17 & 0.28 & & \\
\hline \multicolumn{8}{|l|}{ 119B-746A- } \\
\hline $4 \mathrm{H}-1,48-50$ & 165.26 & 34.8 & 65.2 & 0.14 & 0.40 & 11.0 & 2.7 \\
\hline $4 \mathrm{H}-2,48-50$ & 166.70 & 42.7 & 57.4 & 0.13 & 0.47 & & \\
\hline $4 \mathrm{H}-3,48-50$ & 168.15 & 48.8 & 51.2 & 0.23 & 0.55 & & \\
\hline $4 \mathrm{H}-4,48-50$ & 169.59 & 33.9 & 66.1 & 0.11 & 0.36 & & \\
\hline $4 \mathrm{H}-5,48-50$ & 171.03 & 44.1 & 55.9 & 0.10 & 0.30 & 12.7 & 2.5 \\
\hline $4 \mathrm{H}-6,48-50$ & 172.47 & 33.1 & 66.9 & 0.10 & 0.44 & & \\
\hline $4 \mathrm{H}-7,48-50$ & 173.92 & 48.0 & 52.0 & 0.16 & 0.38 & & \\
\hline $5 \mathrm{H}-1,48-50$ & 174.75 & 32.0 & 68.0 & 0.13 & 0.37 & & \\
\hline $5 \mathrm{H}-2,48-50$ & 176.18 & 43.1 & 56.9 & 0.07 & 0.37 & 8.1 & 1.7 \\
\hline $5 \mathrm{H}-3,48-50$ & 177.60 & 49.2 & 50.8 & 0.01 & 0.82 & & \\
\hline $5 \mathrm{H}-4,48-50$ & 179.02 & 38.8 & 61.2 & 0.15 & 0.43 & & \\
\hline $5 \mathrm{H}-5,48-50$ & 180.44 & 36.7 & 63.3 & 0.13 & 0.36 & & \\
\hline $5 \mathrm{H}-6,48-50$ & 181.86 & 23.7 & 76.3 & 0.08 & 0.35 & 18.9 & 4.0 \\
\hline $5 \mathrm{H}-7,48-50$ & 183.28 & 39.0 & 61.0 & 0.07 & 0.32 & & \\
\hline $6 \mathrm{H}-1,48-50$ & 184.27 & 35.7 & 64.3 & 0.08 & 0.46 & & \\
\hline $6 \mathrm{H}-2,48-50$ & 185.74 & 37.1 & 62.9 & 0.11 & 0.29 & 13.2 & 2.8 \\
\hline $6 \mathrm{H}-3,48-50$ & 187.21 & 39.9 & 60.1 & 0.04 & 0.67 & & \\
\hline $6 \mathrm{H}-4,48-50$ & 188.68 & 26.7 & 73.4 & 0.14 & 0.44 & & \\
\hline $6 \mathrm{H}-5,48-50$ & 190.15 & 36.1 & 63.9 & 0.12 & 0.37 & & \\
\hline $6 \mathrm{H}-6,48-50$ & 191.62 & 40.3 & 59.7 & 0.10 & 0.33 & 11.8 & 2.1 \\
\hline $6 \mathrm{H}-7,5-7$ & 192.67 & 46.9 & 53.2 & 0.11 & 0.27 & & \\
\hline $7 \mathrm{H}-1,48-50$ & 193.77 & 44.6 & 55.5 & 0.07 & 0.40 & & \\
\hline $7 \mathrm{H}-2,48-50$ & 195.22 & 43.8 & 56.2 & 0.06 & 0.82 & & \\
\hline $7 \mathrm{H}-3,48-50$ & 196.68 & 40.5 & 59.5 & 0.11 & 0.34 & 13.8 & 3.1 \\
\hline $7 \mathrm{H}-4,48-50$ & 198.13 & 39.7 & 60.3 & 0.13 & 0.47 & & \\
\hline $7 \mathrm{H}-5,48-50$ & 199.59 & 53.3 & 46.7 & 0.15 & 0.31 & & \\
\hline $7 \mathrm{H}-6,48-50$ & 201.05 & 36.6 & 63.4 & 0.13 & 0.58 & & \\
\hline $7 \mathrm{H}-7,48-50$ & 202.50 & 39.3 & 60.7 & 0.11 & 0.61 & 11.5 & 3.6 \\
\hline $8 \mathrm{H}-1,48-50$ & 203.28 & 38.3 & 61.8 & 0.09 & 0.38 & & \\
\hline $8 \mathrm{H}-2,48-50$ & 204.78 & 41.0 & 59.0 & 0.09 & 0.42 & & \\
\hline $8 \mathrm{H}-3,48-50$ & 206.28 & 50.8 & 49.2 & 0.10 & 0.17 & & \\
\hline $8 \mathrm{H}-5,48-50$ & 207.93 & 51.7 & 48.4 & 0.10 & 0.38 & 11.8 & 3.2 \\
\hline $9 \mathrm{H}-4,42-44$ & 214.22 & 42.3 & 57.7 & 0.16 & 0.37 & & \\
\hline $9 \mathrm{H}-5,42-44$ & 215.72 & 44.7 & 55.3 & 0.08 & 0.63 & 12.0 & 3.2 \\
\hline $9 \mathrm{H}-6,42-44$ & 217.22 & 34.6 & 65.4 & 0.13 & 0.30 & & \\
\hline $10 \mathrm{H}-1,48-50$ & 218.26 & 45.9 & 54.1 & 0.10 & 0.23 & 9.5 & 3.3 \\
\hline $10 \mathrm{H}-2,48-50$ & 219.70 & 37.8 & 62.2 & 0.13 & 0.24 & & \\
\hline $10 \mathrm{H}-3,48-50$ & 221.15 & 34.7 & 65.3 & 0.15 & 0.59 & & \\
\hline $10 \mathrm{H}-4,48-50$ & 222.59 & 41.2 & 58.8 & 0.16 & 0.53 & & \\
\hline $10 \mathrm{H}-5,48-50$ & 224.03 & 46.4 & 53.7 & 0.18 & 0.37 & 6.0 & 1.0 \\
\hline $10 \mathrm{H}-6,48-50$ & 225.47 & 44.3 & 55.7 & 0.11 & 0.42 & & \\
\hline $11 X-1,48-50$ & 227.67 & 35.8 & 64.2 & 0.18 & 0.32 & & \\
\hline $11 X-2,48-50$ & 228.83 & 39.6 & 60.4 & 0.12 & 0.36 & & \\
\hline $11 X-3,48-50$ & 230.00 & 41.1 & 58.9 & 0.12 & 0.36 & 12.1 & 3.9 \\
\hline $11 X-4,48-50$ & 231.16 & 49.1 & 50.9 & 0.16 & 0.42 & & \\
\hline $11 X-5,48-50$ & 232.32 & 31.2 & 68.8 & 0.23 & 0.24 & & \\
\hline $11 X-6,48-50$ & 233.49 & 32.4 & 67.6 & 0.24 & 0.22 & 8.1 & 3.5 \\
\hline $13 X-1,48-50$ & 242.67 & 44.9 & 55.1 & 0.08 & 2.92 & 13.6 & 2.6 \\
\hline $13 X-2,48-50$ & 244.14 & 39.5 & 60.5 & 0.09 & 3.62 & & \\
\hline $13 X-3,48-50$ & 245.61 & 40.1 & 59.9 & 0.18 & 1.42 & & \\
\hline $13 X-4,48-50$ & 247.08 & 32.7 & 67.3 & 0.19 & 27.15 & & \\
\hline $13 X-5,48-50$ & 248.55 & 40.7 & 59.3 & 0.11 & 0.66 & 9.7 & 4.1 \\
\hline $13 X-6,48-50$ & 250.02 & 45.8 & 54.2 & 0.14 & 2.38 & & \\
\hline $14 \mathrm{X}-1,48-50$ & 252.28 & 7.7 & 92.3 & 0.20 & 1.28 & 11.1 & 3.2 \\
\hline $15 X-1,48-50$ & 261.98 & 36.7 & 63.3 & 0.27 & 0.32 & 12.2 & 3.5 \\
\hline $16 \mathrm{X}-1,48-50$ & 271.58 & 36.6 & 63.4 & 0.12 & 0.21 & 8.3 & 2.4 \\
\hline
\end{tabular}


Appendix Table 3. Number of granules and pebbles in core sections from ODP Sites 745 and 746 as deduced from the shipboard visual core descriptions.

\begin{tabular}{lcc}
\hline Core, section & $\begin{array}{c}\text { Depth } \\
\text { (mbsf) }\end{array}$ & $\begin{array}{c}\text { Granules and } \\
\text { pebbles }\end{array}$ \\
\hline
\end{tabular}

119-745B-

\begin{tabular}{|c|c|c|}
\hline $1 \mathrm{H}-1$ & 0.74 & 0 \\
\hline $1 \mathrm{H}-2$ & 2.21 & 0 \\
\hline $1 \mathrm{H}-3$ & 3.68 & 0 \\
\hline $1 \mathrm{H}-4$ & 4.66 & 0 \\
\hline $2 \mathrm{H}-1$ & 5.73 & 0 \\
\hline $2 \mathrm{H}-2$ & 7.18 & 0 \\
\hline $2 \mathrm{H}-3$ & 8.64 & 0 \\
\hline $2 \mathrm{H}-4$ & 10.10 & 0 \\
\hline $2 \mathrm{H}-5$ & 11.55 & 0 \\
\hline $2 \mathrm{H}-6$ & 13.01 & 0 \\
\hline $2 \mathrm{H}-7$ & 14.13 & 0 \\
\hline $3 \mathrm{H}-1$ & 15.25 & 0 \\
\hline $3 \mathrm{H}-2$ & 16.75 & 0 \\
\hline $3 \mathrm{H}-3$ & 18.25 & 0 \\
\hline $3 \mathrm{H}-4$ & 19.75 & 0 \\
\hline $3 \mathrm{H}-5$ & 21.25 & 0 \\
\hline $3 \mathrm{H}-6$ & 22.75 & 1 \\
\hline $3 \mathrm{H}-7$ & 23.72 & 0 \\
\hline $4 \mathrm{H}-1$ & 24.73 & 0 \\
\hline $4 \mathrm{H}-2$ & 26.18 & 0 \\
\hline $4 \mathrm{H}-3$ & 27.64 & 0 \\
\hline $4 \mathrm{H}-4$ & 29.10 & 0 \\
\hline $4 \mathrm{H}-5$ & 30.55 & 1 \\
\hline $4 \mathrm{H}-6$ & 32.01 & 0 \\
\hline $4 \mathrm{H}-7$ & 33.13 & 0 \\
\hline $5 \mathrm{H}-1$ & 34.23 & 0 \\
\hline $5 \mathrm{H}-2$ & 35.68 & 0 \\
\hline $5 \mathrm{H}-3$ & 37.14 & 0 \\
\hline $5 \mathrm{H}-4$ & 38.60 & 0 \\
\hline $5 \mathrm{H}-5$ & 40.05 & 0 \\
\hline $5 \mathrm{H}-6$ & 41.51 & 0 \\
\hline $5 \mathrm{H}-7$ & 42.64 & 0 \\
\hline $6 \mathrm{H}-1$ & 43.73 & 0 \\
\hline $6 \mathrm{H}-2$ & 45.18 & 0 \\
\hline $6 \mathrm{H}-3$ & 46.64 & 0 \\
\hline $6 \mathrm{H}-4$ & 48.10 & 0 \\
\hline $6 \mathrm{H}-5$ & 49.55 & 0 \\
\hline $6 \mathrm{H}-6$ & 51.01 & 0 \\
\hline $6 \mathrm{H}-7$ & 52.16 & 0 \\
\hline $7 \mathrm{H}-1$ & 53.23 & 0 \\
\hline $7 \mathrm{H}-2$ & 54.68 & 2 \\
\hline $7 \mathrm{H}-3$ & 56.14 & 2 \\
\hline $7 \mathrm{H}-4$ & 57.60 & 5 \\
\hline $7 \mathrm{H}-5$ & 59.05 & 4 \\
\hline $7 \mathrm{H}-6$ & 60.51 & 0 \\
\hline $7 \mathrm{H}-7$ & 61.61 & 2 \\
\hline $8 \mathrm{H}-1$ & 62.73 & 0 \\
\hline $8 \mathrm{H}-2$ & 64.18 & 4 \\
\hline $8 \mathrm{H}-3$ & 65.64 & 1 \\
\hline $8 \mathrm{H}-4$ & 67.10 & 5 \\
\hline $8 \mathrm{H}-5$ & 68.55 & 0 \\
\hline $8 \mathrm{H}-6$ & 70.01 & 5 \\
\hline $8 \mathrm{H}-7$ & 71.56 & 0 \\
\hline $9 \mathrm{H}-1$ & 72.21 & 1 \\
\hline $9 \mathrm{H}-2$ & 73.63 & 0 \\
\hline $9 \mathrm{H}-3$ & 75.05 & 0 \\
\hline $9 \mathrm{H}-4$ & 76.47 & 0 \\
\hline $9 \mathrm{H}-5$ & 77.89 & 0 \\
\hline $9 \mathrm{H}-6$ & 79.31 & 0 \\
\hline $9 \mathrm{H}-7$ & 80.52 & 1 \\
\hline $10 \mathrm{H}-1$ & 81.72 & 2 \\
\hline $10 \mathrm{H}-2$ & 83.16 & 0 \\
\hline $10 \mathrm{H}-3$ & 84.61 & 1 \\
\hline $10 \mathrm{H}-4$ & 86.05 & 0 \\
\hline $10 \mathrm{H}-5$ & 87.49 & 1 \\
\hline $10 \mathrm{H}-6$ & 88.93 & 1 \\
\hline $10 \mathrm{H}-7$ & 90.45 & 2 \\
\hline $11 \mathrm{H}-1$ & 91.23 & 10 \\
\hline $11 \mathrm{H}-2$ & 92.68 & 1 \\
\hline $11 \mathrm{H}-3$ & 94.14 & 0 \\
\hline $11 \mathrm{H}-4$ & 95.60 & 0 \\
\hline $11 \mathrm{H}-5$ & 97.05 & 2 \\
\hline
\end{tabular}

Appendix Table 3 (continued).

\begin{tabular}{lcc}
\hline Core, section & $\begin{array}{c}\text { Depth } \\
\text { (mbsf) }\end{array}$ & $\begin{array}{c}\text { Granules and } \\
\text { pebbles }\end{array}$
\end{tabular}

119-745B-(Cont.)

$11 \mathrm{H}-7$

$12 \mathrm{H}-1$

$12 \mathrm{H}-3$

$12 \mathrm{H}-3$

$12 \mathrm{H}-5$

$12 \mathrm{H}-6$

12H-7

$13 \mathrm{H}-1$

$13 \mathrm{H}-2$
$13 \mathrm{H}-3$

$13 \mathrm{H}-4$

$13 \mathrm{H}-5$

$13 \mathrm{H}-6$

$13 \mathrm{H}-7$

$14 \mathrm{H}-1$

$14 \mathrm{H}-2$

$14 \mathrm{H}-3$

$14 \mathrm{H}-4$

14H-5

$14 \mathrm{H}-6$

$14 \mathrm{H}-7$

$15 \mathrm{H}-1$

$15 \mathrm{H}-2$

$15 \mathrm{H}-3$

$15 \mathrm{H}-4$

$15 \mathrm{H}-5$

$15 \mathrm{H}-6$
$17 \mathrm{H}-1$

$17 \mathrm{H}-2$

$17 \mathrm{H}-3$

$17 \mathrm{H}-4$
$17 \mathrm{H}-5$

$17 \mathrm{H}-5$

$17 \mathrm{H}-7$

$18 \mathrm{H}-$

$18 \mathrm{H}-2$

$18 \mathrm{H}-3$

$18 \mathrm{H}-4$

$18 \mathrm{H}-5$

$18 \mathrm{H}-6$

18H-7

$19 \mathrm{H}-2$

$19 \mathrm{H}-3$

$19 \mathrm{H}-4$

$19 \mathrm{H}-5$

$19 \mathrm{H}-6$

$19 \mathrm{H}-7$

20H-1

20H-2

$20 \mathrm{H}-3$

$20 \mathrm{H}-4$

20H-5

20H-6

$20 \mathrm{H}-7$

21H-

$21 \mathrm{H}-2$

$21 \mathrm{H}-3$

$21 \mathrm{H}-4$

21H-5

$21 \mathrm{H}-6$

$21 \mathrm{H}-7$

22H-1

$22 \mathrm{H}-2$

$22 \mathrm{H}-3$

$22 \mathrm{H}-4$

22H-5

$22 \mathrm{H}-6$

$22 \mathrm{H}-7$

23H-1

$23 \mathrm{H}-2$

$23 \mathrm{H}-3$

$23 \mathrm{H}-4$
$23 \mathrm{H}-5$

23H-5

23H-6

199.57

201.00

202.43

$\begin{array}{rr}98.51 & 2 \\ 99.63 & 0 \\ 100.71 & 2 \\ 102.13 & 2 \\ 103.55 & 4 \\ 104.97 & 0 \\ 106.39 & 5 \\ 107.81 & 2 \\ 109.01 & 0\end{array}$

Appendix Table 3 (continued).

\begin{tabular}{lcc}
\hline Core, section & $\begin{array}{c}\text { Depth } \\
\text { (mbsf) }\end{array}$ & $\begin{array}{c}\text { Granules and } \\
\text { pebbles }\end{array}$ \\
\hline $119-745 B-($ Cont.)
\end{tabular}

$\begin{array}{lll}23 \mathrm{H}-7 & 205.03 & 0 \\ 24 \mathrm{H}-1 & 206.21 & 3 \\ 24 \mathrm{H}-2 & 207.62 & 1 \\ 24 \mathrm{H}-3 & 209.04 & 2 \\ 24 \mathrm{H}-4 & 210.46 & 5 \\ 24 \mathrm{H}-5 & 211.87 & 1 \\ 24 \mathrm{H}-6 & 213.29 & 0 \\ 24 \mathrm{H}-7 & 214.49 & 0\end{array}$

119-746A-

2H-1 107.55

$2 \mathrm{H}-2$

$2 \mathrm{H}-3$

110.55

112.05

2H-5 113.02

$4 \mathrm{H}-1 \quad 165.52$

$4 \mathrm{H}-2 \quad 166.96$

$4 \mathrm{H}-3 \quad 168.41$

4H-4 169.85

4H-5 $\quad 171.29$

$4 \mathrm{H}-6 \quad 172.73$

$4 \mathrm{H}-7 \quad 173.85$

$5 \mathrm{H}-1 \quad 175.01$

$5 \mathrm{H}-2 \quad 176.43$

$5 \mathrm{H}-3 \quad 177.85$

$5 \mathrm{H}-4 \quad 179.27$

$5 \mathrm{H}-5 \quad 180.69$

$5 \mathrm{H}-6 \quad 182.11$

5H-7 183.32

$6 \mathrm{H}-1 \quad 184.54$

$6 \mathrm{H}-2 \quad 186.0$

$6 \mathrm{H}-3 \quad 187.48$

$6 \mathrm{H}-4 \quad 188.95$

$6 \mathrm{H}-5 \quad 190.42$

$6 \mathrm{H}-6 \quad 191.89$

$6 \mathrm{H}-7 \quad 192.97$

7H-1 194.03

$7 \mathrm{H}-2 \quad 195.48$

$7 \mathrm{H}-3 \quad 196.94$

$7 \mathrm{H}-4 \quad 198.40$

$7 \mathrm{H}-5 \quad 199.85$

7H-6 201.31

7H-7 202.44

$8 \mathrm{H}-1 \quad 203.55$

$8 \mathrm{H}-2 \quad 205.05$

$8 \mathrm{H}-3 \quad 206.55$

$8 \mathrm{H}-5 \quad 208.05$

$9 \mathrm{H}-4 \quad 214.55$

9H-5 216.05

9H-6 217.26

$10 \mathrm{H}-1 \quad 218.52$

$10 \mathrm{H}-2 \quad 219.96$

$10 \mathrm{H}-3 \quad 221.41$

$10 \mathrm{H}-4 \quad 222.85$

$10 \mathrm{H}-5 \quad 224.29$

$10 \mathrm{H}-6 \quad 225.73$

11X-1 227.88

$11 X-2 \quad 229.04$

$11 X-3 \quad 230.21$

$11 X-4 \quad 231.37$

$11 X-5 \quad 232.53$

$11 X-6 \quad 233.70$

$11 X-7 \quad 234.56$

$13 X-1 \quad 242.94$

$13 X-2 \quad 244.41$

$13 \mathrm{X}-3 \quad 245.88$

$13 X-4 \quad 247.35$

$13 \mathrm{X}-5 \quad 248.82$

13X-6 250.29

13X-7 251.42

$14 X-1 \quad 252.55$

$15 \mathrm{X}-1 \quad 262.25$

$16 \mathrm{X}-1 \quad 271.85$ 
Appendix Table 4. Grain-size distribution of the terrigenous sediment components at ODP Sites $\mathbf{7 4 5}$ and $\mathbf{7 4 6}$. The number of pebbles and granules $(>\mathbf{2 m m})$ is also listed.

\begin{tabular}{|c|c|c|c|c|c|c|}
\hline \multirow{2}{*}{$\begin{array}{l}\text { Core, section, } \\
\text { interval }(\mathrm{cm})\end{array}$} & \multirow{2}{*}{$\begin{array}{l}\text { Depth } \\
\text { (mbsf) }\end{array}$} & \multicolumn{2}{|c|}{$>2 \mathrm{~mm}$} & \multirow{2}{*}{$\begin{array}{c}63 \mu \mathrm{m}-2 \mathrm{~mm} \\
(\%)\end{array}$} & \multirow{2}{*}{$\begin{array}{c}2-63 \mu \mathrm{m} \\
(\%)\end{array}$} & \multirow{2}{*}{$\begin{array}{c}<2 \mu \mathrm{m} \\
(\%)\end{array}$} \\
\hline & & $(n)$ & $(\%)$ & & & \\
\hline \multicolumn{7}{|l|}{$119-745 B-$} \\
\hline $1 \mathrm{H}-1,48-50$ & 0.47 & 0 & 0.0 & 0.2 & 17.3 & 82.5 \\
\hline IH $-3,48-50$ & 3.41 & 0 & 0.0 & 0.0 & 36.1 & 63.8 \\
\hline $1 \mathrm{H}-4,20-22$ & 4.61 & 0 & 0.0 & 0.0 & 37.7 & 62.3 \\
\hline $2 \mathrm{H}-1,48-50$ & 5.47 & 0 & 0.0 & 1.4 & 33.3 & 65.2 \\
\hline $2 \mathrm{H}-2,48-50$ & 6.92 & 0 & 0.0 & 1.8 & 20.5 & 77.8 \\
\hline $2 \mathrm{H}-3,48-50$ & 8.38 & 0 & 0.0 & 1.2 & 24.3 & 74.5 \\
\hline $2 \mathrm{H}-4,48-50$ & 9.83 & 0 & 0.0 & 0.2 & 31.0 & 68.8 \\
\hline $2 \mathrm{H}-5,48-50$ & 11.29 & 0 & 0.0 & 0.4 & 14.8 & 84.8 \\
\hline $2 \mathrm{H}-6,48-50$ & 12.75 & 0 & 0.0 & 0.0 & 30.4 & 69.6 \\
\hline $2 \mathrm{H}-7,48-50$ & 14.20 & 0 & 0.0 & 0.0 & 30.2 & 69.8 \\
\hline $3 \mathrm{H}-1,48-50$ & 14.98 & 0 & 0.0 & 0.5 & 13.5 & 86.0 \\
\hline $3 \mathrm{H}-2,48-50$ & 16.48 & 0 & 0.0 & 0.2 & 33.7 & 66.1 \\
\hline $3 \mathrm{H}-3,48-50$ & 17.98 & 0 & 0.0 & 0.0 & 16.8 & 83.2 \\
\hline $3 \mathrm{H}-4,48-50$ & 19.48 & 0 & 0.0 & 0.2 & 17.8 & 82.0 \\
\hline $3 \mathrm{H}-5,48-50$ & 20.98 & 0 & 0.0 & 0.2 & 32.8 & 66.9 \\
\hline $3 \mathrm{H}-6,49-52$ & 22.49 & 0 & 0.0 & 2.4 & 34.2 & 63.4 \\
\hline $4 \mathrm{H}-1,50-52$ & 24.48 & 1 & 2.6 & 0.8 & 22.8 & 73.8 \\
\hline $4 \mathrm{H}-2,50-52$ & 25.94 & 0 & 0.0 & 0.1 & 38.8 & 61.1 \\
\hline $4 \mathrm{H}-3,50-52$ & 27.40 & 0 & 0.0 & 0.0 & 37.7 & 62.3 \\
\hline $4 \mathrm{H}-4,50-52$ & 28.85 & 0 & 0.0 & 0.2 & 16.8 & 83.0 \\
\hline $4 \mathrm{H}-5,50-52$ & 30.31 & 0 & 0.0 & 5.5 & 15.0 & 79.5 \\
\hline $4 \mathrm{H}-6,50-52$ & 31.77 & 0 & 0.0 & 0.2 & 24.5 & 75.3 \\
\hline $4 \mathrm{H}-7,50-52$ & 33.22 & 0 & 0.0 & 0.4 & 22.5 & 77.2 \\
\hline $5 \mathrm{H}-1,48-50$ & 33.97 & 0 & 0.0 & 0.3 & 25.7 & 74.0 \\
\hline $5 \mathrm{H}-2,48-50$ & 35.42 & 0 & 0.0 & 0.2 & 39.3 & 60.5 \\
\hline $5 \mathrm{H}-3,48-50$ & 36.88 & 0 & 0.0 & 0.6 & 35.5 & 64.0 \\
\hline $5 \mathrm{H}-4,48-50$ & 38.33 & 0 & 0.0 & 0.0 & 24.0 & 76.0 \\
\hline $5 \mathrm{H}-5,48-50$ & 39.79 & 0 & 0.0 & 0.2 & 31.9 & 67.9 \\
\hline $5 \mathrm{H}-6,48-50$ & 41.25 & 0 & 0.0 & 0.2 & 28.8 & 71.0 \\
\hline $5 \mathrm{H}-7,48-50$ & 42.70 & 0 & 0.0 & 0.1 & 31.9 & 68.0 \\
\hline $6 \mathrm{H}-1,48-50$ & 43.48 & 0 & 0.0 & 0.8 & 32.8 & 66.4 \\
\hline $6 \mathrm{H}-2,48-50$ & 44.98 & 0 & 0.0 & 0.2 & 41.4 & 58.4 \\
\hline $6 \mathrm{H}-3,48-50$ & 46.48 & 0 & 0.0 & 0.2 & 33.1 & 66.8 \\
\hline $6 \mathrm{H}-4,48-50$ & 47.98 & 0 & & & & \\
\hline $6 \mathrm{H}-5,43-45$ & 49.43 & 0 & 0.0 & 0.0 & 48.8 & 51.2 \\
\hline $6 \mathrm{H}-6,48-50$ & 50.98 & 0 & 0.0 & 3.3 & 30.6 & 66.0 \\
\hline $7 \mathrm{H}-1,48-50$ & 52.97 & 0 & 0.0 & 0.1 & 51.2 & 48.7 \\
\hline $7 \mathrm{H}-2,48-50$ & 54.42 & 0 & 0.0 & 0.1 & 35.3 & 64.6 \\
\hline $7 \mathrm{H}-3,48-50$ & 55.88 & 0 & 0.0 & 0.2 & 24.1 & 75.7 \\
\hline $7 \mathrm{H}-4,48-50$ & 57.33 & 0 & 0.0 & 0.5 & 17.0 & 82.5 \\
\hline $7 \mathrm{H}-5,48-50$ & 58.79 & 0 & 0.0 & 0.8 & 30.3 & 68.8 \\
\hline $7 \mathrm{H}-6,48-50$ & 60.25 & 0 & 0.0 & 0.0 & 41.6 & 58.4 \\
\hline $7 \mathrm{H}-7,48-50$ & 61.70 & 1 & 1.0 & 1.2 & 42.3 & 55.6 \\
\hline $8 \mathrm{H}-1,48-50$ & 62.47 & 0 & 0.0 & 3.7 & 41.1 & 55.2 \\
\hline $8 \mathrm{H}-2,48-50$ & 63.92 & 0 & 0.0 & 0.0 & 26.0 & 74.0 \\
\hline $8 \mathrm{H}-3,48-50$ & 65.38 & 0 & 0.0 & 0.2 & 27.1 & 72.8 \\
\hline $8 \mathrm{H}-4,48-50$ & 66.83 & 0 & 0.0 & 0.1 & 31.9 & 68.0 \\
\hline $8 \mathrm{H}-5,48-50$ & 68.29 & 0 & 0.0 & 0.0 & 29.4 & 70.6 \\
\hline $8 \mathrm{H}-6,48-50$ & 69.75 & 0 & 0.0 & 1.9 & 10.8 & 87.2 \\
\hline $8 \mathrm{H}-7,48-50$ & 71.20 & 0 & 0.0 & 2.9 & 27.0 & 70.1 \\
\hline $9 \mathrm{H}-1,48-50$ & 71.95 & 0 & 0.0 & 0.2 & 6.6 & 93.3 \\
\hline $9 \mathrm{H}-2,48-50$ & 73.38 & 0 & 0.0 & 0.0 & 27.7 & 72.3 \\
\hline $9 \mathrm{H}-3,48-50$ & 74.80 & 0 & 0.0 & 0.0 & 33.3 & 66.7 \\
\hline $9 \mathrm{H}-4,48-50$ & 76.22 & 0 & 0.0 & 0.1 & 20.8 & 79.1 \\
\hline $9 \mathrm{H}-5,48-50$ & 77.64 & 0 & 0.0 & 0.7 & 37.2 & 62.1 \\
\hline $9 \mathrm{H}-6,48-50$ & 79.06 & 0 & 0.0 & 0.0 & 14.1 & 85.9 \\
\hline $9 \mathrm{H}-7,48-50$ & 80.48 & 0 & 0.0 & 0.2 & 31.2 & 68.6 \\
\hline $10 \mathrm{H}-1,48-50$ & 81.46 & 0 & 0.0 & 0.5 & 27.3 & 72.3 \\
\hline $10 \mathrm{H}-2,48-50$ & 82.90 & 0 & 0.0 & 0.2 & 32.6 & 67.3 \\
\hline $10 \mathrm{H}-3,48-50$ & 84.35 & 0 & 0.0 & 0.5 & 28.0 & 71.5 \\
\hline $10 \mathrm{H}-4,48-50$ & 85.79 & 0 & 0.0 & 0.2 & 25.1 & 74.7 \\
\hline $10 \mathrm{H}-5,48-50$ & 87.23 & 0 & 0.0 & 0.1 & 32.5 & 67.5 \\
\hline $10 \mathrm{H}-6,48-50$ & 88.67 & 0 & 0.0 & 1.0 & 28.6 & 70.4 \\
\hline $10 \mathrm{H}-7,48-50$ & 90.12 & 0 & 0.0 & 3.3 & 3.1 & 93.6 \\
\hline $11 \mathrm{H}-1,48-50$ & 90.97 & 0 & 0.0 & 1.9 & 31.3 & 66.8 \\
\hline $11 \mathrm{H}-2,48-50$ & 92.42 & 0 & 0.0 & 1.1 & 24.4 & 74.5 \\
\hline $11 \mathrm{H}-3,48-50$ & 93.88 & 0 & 0.0 & 0.0 & 37.0 & 63.0 \\
\hline $11 \mathrm{H}-4,48-50$ & 95.33 & 0 & 0.0 & 0.1 & 26.4 & 73.5 \\
\hline $11 \mathrm{H}-5,48-50$ & 96.79 & 4 & 7,4 & 1.8 & 26.8 & 63.9 \\
\hline $11 \mathrm{H}-6,48-50$ & 98.25 & 0 & 0.0 & 1.0 & 34.8 & 64.2 \\
\hline $12 \mathrm{H}-1,48-50$ & 100.45 & 0 & 0.0 & 0.0 & 16.3 & 83.7 \\
\hline $12 \mathrm{H}-2,48-50$ & 101.88 & 0 & 0.0 & 2.9 & 32.2 & 64.9 \\
\hline $12 \mathrm{H}-3,48-50$ & 103.30 & 0 & 0.0 & 0.6 & 32.8 & 66.6 \\
\hline $12 \mathrm{H}-4,48-50$ & 104.72 & 0 & 0.0 & 0.8 & 24.2 & 75.0 \\
\hline
\end{tabular}

Appendix Table 4 (continued).

\begin{tabular}{|c|c|c|c|c|c|c|}
\hline \multirow{2}{*}{$\begin{array}{l}\text { Core, section, } \\
\text { interval }(\mathrm{cm})\end{array}$} & \multirow{2}{*}{$\begin{array}{l}\text { Depth } \\
\text { (mbsf) }\end{array}$} & \multicolumn{2}{|c|}{$>2 \mathrm{~mm}$} & \multirow{2}{*}{$\begin{array}{c}63 \mu \mathrm{m}-2 \\
(\%)\end{array}$} & \multirow{2}{*}{$\begin{array}{c}2-63 \mu \mathrm{m} \\
(\%)\end{array}$} & \multirow{2}{*}{$\begin{array}{l}<2 \mu \mathrm{m} \\
(\%)\end{array}$} \\
\hline & & (n) & $(\%)$ & & & \\
\hline 119-745B-(Cont.) & & & & & & \\
\hline $12 \mathrm{H}-5,48-50$ & 106.14 & 0 & 0.0 & 0.6 & 35.1 & 64.3 \\
\hline $12 \mathrm{H}-6,48-50$ & 107.56 & 0 & 0.0 & 0.8 & 31.9 & 67.3 \\
\hline $12 \mathrm{H}-7,48-50$ & 108.98 & 1 & 1.5 & 0.7 & 35.0 & 62.8 \\
\hline $13 \mathrm{H}-1,48-50$ & 109.96 & 0 & 0.0 & 0.3 & 21.7 & 78.0 \\
\hline $13 \mathrm{H}-2,48-50$ & 111.39 & 0 & 0.0 & 0.7 & 41.0 & 58.3 \\
\hline $13 \mathrm{H}-3,48-50$ & 112.81 & 0 & 0.0 & 0.9 & 28.0 & 71.1 \\
\hline $13 \mathrm{H}-4,48-50$ & 114.24 & 0 & 0.0 & 1.0 & 17.7 & 81.3 \\
\hline $13 \mathrm{H}-5,48-50$ & 115.67 & 1 & 0.3 & 0.8 & 20.1 & 78.8 \\
\hline $13 \mathrm{H}-6,48-50$ & 117.10 & 0 & 0.0 & 1.8 & 2.7 & 95.5 \\
\hline $13 \mathrm{H}-7,48-50$ & 118.53 & 1 & 0.6 & 1.1 & 5.6 & 92.6 \\
\hline $14 \mathrm{H}-1,48-50$ & 119.46 & 1 & 0.1 & 2.6 & 23.7 & 73.7 \\
\hline $14 \mathrm{H}-2,48-50$ & 120.90 & 1 & 0.8 & 0.8 & 47.7 & 50.8 \\
\hline $14 \mathrm{H}-3,48-50$ & 122.35 & 0 & 0.0 & 0.0 & 26.8 & 73.2 \\
\hline $14 \mathrm{H}-4,48-50$ & 123.79 & 0 & 0.0 & 1.5 & 44.3 & 54.2 \\
\hline $14 \mathrm{H}-5,48-50$ & 125.23 & 0 & 0.0 & 1.3 & 35.3 & 63.4 \\
\hline $14 \mathrm{H}-6,48-50$ & 126.67 & 0 & 0.0 & 0.1 & 28.0 & 71.9 \\
\hline $14 \mathrm{H}-7,48-50$ & 128.12 & 0 & 0.0 & 0.5 & 23.3 & 76.3 \\
\hline $15 \mathrm{H}-1,48-50$ & 128.98 & 0 & 0.0 & 0.5 & 24.1 & 75.4 \\
\hline $15 \mathrm{H}-2,48-50$ & 130.48 & 0 & 0.0 & 1.1 & 19.7 & 79.1 \\
\hline $15 \mathrm{H}-3,48-50$ & 131.98 & 1 & 0.4 & 1.2 & 39.4 & 59.1 \\
\hline $15 \mathrm{H}-4,48-50$ & 133.48 & 0 & 0.0 & 2.2 & 22.8 & 75.1 \\
\hline $15 \mathrm{H}-5,48-50$ & 134.98 & 0 & 0.0 & 3.5 & 20.3 & 76.2 \\
\hline $15 \mathrm{H}-6,48-50$ & 136.48 & 0 & 0.0 & 1.4 & 33.2 & 65.4 \\
\hline $17 \mathrm{H}-1,48-50$ & 139.47 & 0 & 0.0 & 0.0 & 25.0 & 75.0 \\
\hline $17 \mathrm{H}-2,48-50$ & 140.94 & 0 & 0.0 & 6.2 & 28.0 & 65.8 \\
\hline $17 \mathrm{H}-3,48-50$ & 142.41 & 0 & 0.0 & 8.3 & 31.2 & 60.5 \\
\hline $17 \mathrm{H}-4,48-50$ & 143.88 & 0 & 0.0 & 0.0 & 33.2 & 66.8 \\
\hline $17 \mathrm{H}-5,48-50$ & 145.35 & 0 & 0.0 & 0.7 & 2.7 & 96.7 \\
\hline $17 \mathrm{H}-6,48-50$ & 146.82 & 0 & 0.0 & 0.2 & 43.5 & 56.3 \\
\hline $17 \mathrm{H}-7,46-48$ & 148.27 & 0 & 0.0 & 1.0 & 31.3 & 67.6 \\
\hline $18 \mathrm{H}-1,44-46$ & 148.92 & 0 & 0.0 & 0.0 & 26.5 & 73.5 \\
\hline $18 \mathrm{H}-2,44-46$ & 150.37 & 0 & 0.0 & 0.3 & 22.4 & 77.3 \\
\hline $18 \mathrm{H}-3,44-46$ & 151.81 & 0 & & & & \\
\hline $18 \mathrm{H}-4,44-46$ & 153.25 & 0 & 0.0 & 0.1 & 24.3 & 75.6 \\
\hline $18 \mathrm{H}-5,44-46$ & 154.69 & 0 & 0.0 & 0.2 & 40.5 & 59.3 \\
\hline $18 \mathrm{H}-6,44-46$ & 156.13 & 1 & 0.4 & 0.2 & 16.9 & 82.5 \\
\hline $18 \mathrm{H}-7,44-46$ & 157.58 & 0 & 0.0 & 1.2 & 22.0 & 76.8 \\
\hline $19 \mathrm{H}-1,40-42$ & 158.38 & 0 & 0.0 & 0.1 & 46.2 & 53.7 \\
\hline $19 \mathrm{H}-2,40-42$ & 159.80 & 0 & 0.0 & 0.2 & 30.9 & 68.9 \\
\hline $19 \mathrm{H}-3,40-42$ & 161.23 & 0 & & & & \\
\hline $19 \mathrm{H}-4,40-42$ & 162.69 & 1 & 0.9 & 2.5 & 29.0 & 67.7 \\
\hline $19 \mathrm{H}-5,40-42$ & 164.08 & 5 & 2.4 & 3.0 & 21.2 & 73.4 \\
\hline $19 \mathrm{H}-6,40-42$ & 165.50 & 0 & 0.0 & 0.5 & 1.0 & 98.5 \\
\hline $19 \mathrm{H}-7,40-42$ & 166.93 & 0 & 0.0 & 1.8 & 25.1 & 73.1 \\
\hline $20 \mathrm{H}-1,52-54$ & 168.00 & 1 & 0.2 & 5.9 & 39.4 & 54.4 \\
\hline $20 \mathrm{H}-2,47-49$ & 169.39 & 1 & 0.5 & 2.8 & 40.4 & 56.3 \\
\hline $20 \mathrm{H}-3,47-49$ & 170.84 & 0 & 0.0 & 0.7 & 21.5 & 77.9 \\
\hline $20 \mathrm{H}-4,47-49$ & 172.28 & 1 & 0.4 & 0.1 & 19.2 & 80.3 \\
\hline $20 \mathrm{H}-5,47-49$ & 173.72 & 0 & 0.0 & 1.4 & 20.3 & 78.3 \\
\hline $20 \mathrm{H}-6,47-49$ & 175.16 & 0 & 0.0 & 3.0 & 29.5 & 67.5 \\
\hline $20 \mathrm{H}-7,47-49$ & 176.61 & 0 & 0.0 & 0.5 & 19.2 & 80.3 \\
\hline $21 \mathrm{H}-2,48-50$ & 178.88 & 0 & 0.0 & 2.4 & 24.4 & 73.2 \\
\hline $21 \mathrm{H}-3,48-50$ & 180.30 & 0 & 0.0 & 1.6 & 24.8 & 73.6 \\
\hline $21 \mathrm{H}-4,48-50$ & 181.72 & 3 & 1.8 & 0.0 & 37.0 & 61.1 \\
\hline $21 \mathrm{H}-5,48-50$ & 183.14 & 0 & 0.0 & 0.9 & 6.0 & 93.1 \\
\hline $21 \mathrm{H}-6,48-50$ & 184.56 & 1 & 0.4 & 0.7 & 36.5 & 62.5 \\
\hline $21 \mathrm{H}-7,48-50$ & 185.98 & 0 & 0.0 & 0.5 & 27.0 & 72.5 \\
\hline $22 \mathrm{H}-1,48-50$ & 186.98 & 0 & 0.0 & 0.9 & 15.1 & 84.0 \\
\hline $22 \mathrm{H}-2,48-50$ & 188.48 & 0 & 0.0 & 0.2 & 2.8 & 97.0 \\
\hline $22 \mathrm{H}-3,48-50$ & 189.98 & 0 & 0.0 & 0.6 & 40.9 & 58.4 \\
\hline $22 \mathrm{H}-4,48-50$ & 191.48 & 1 & 0.8 & 2.6 & 31.4 & 65.1 \\
\hline $22 \mathrm{H}-5,48-50$ & 192.98 & 0 & 0.0 & 1.0 & 40.3 & 58.7 \\
\hline $22 \mathrm{H}-6,48-50$ & 194.48 & 0 & 0.0 & 0.2 & 20.9 & 78.9 \\
\hline $23 \mathrm{H}-1,48-50$ & 196.46 & 0 & 0.0 & 0.8 & 26.0 & 73.3 \\
\hline $23 \mathrm{H}-2,48-50$ & 197.89 & 0 & 0.0 & 0.0 & 5.2 & 94.7 \\
\hline $23 \mathrm{H}-3,48-50$ & 199.31 & 0 & 0.0 & 0.5 & 34.0 & 65.6 \\
\hline $23 \mathrm{H}-4,48-50$ & 200.74 & 1 & 0.5 & 0.2 & 29.8 & 70.0 \\
\hline $23 \mathrm{H}-5,48-50$ & 202.17 & 0 & 0.0 & 0.1 & 29.7 & 70.2 \\
\hline $23 \mathrm{H}-6,48-50$ & 203.60 & 0 & 0.0 & 0.3 & 35.1 & 64.7 \\
\hline $23 \mathrm{H}-7,48-50$ & 205.03 & 0 & 0.0 & 0.8 & 24.6 & 74.7 \\
\hline $24 \mathrm{H}-1,48-50$ & 205.95 & 0 & 0.0 & 0.1 & 22.8 & 77.2 \\
\hline $24 \mathrm{H}-2,48-50$ & 207.37 & 0 & 0.0 & 1.8 & 38.1 & 60.1 \\
\hline $24 \mathrm{H}-3,48-50$ & 208.79 & 0 & 0.0 & 0.8 & 19.6 & 79.5 \\
\hline $24 \mathrm{H}-4,48-50$ & 210.11 & 0 & 0.0 & 2.9 & 17.8 & 79.3 \\
\hline $24 \mathrm{H}-5,48-50$ & 211.62 & 0 & 0.0 & 0.0 & 14.8 & 85.2 \\
\hline $24 \mathrm{H}-6,48-50$ & 213.04 & 0 & 0.0 & 2.2 & 24.1 & 73.7 \\
\hline $24 \mathrm{H}-7,48-50$ & $214.45^{\circ}$ & 0 & 0.0 & 3.1 & 30.6 & 66.3 \\
\hline
\end{tabular}


Appendix Table 4 (continued).

\begin{tabular}{|c|c|c|c|c|c|c|}
\hline \multirow{2}{*}{$\begin{array}{l}\text { Core, section, } \\
\text { interval }(\mathrm{cm})\end{array}$} & \multirow{2}{*}{$\begin{array}{l}\text { Depth } \\
\text { (mbsf) }\end{array}$} & \multicolumn{2}{|c|}{$>2 \mathrm{~mm}$} & \multirow{2}{*}{$\begin{array}{c}63 \mu \mathrm{m}-2 \mathrm{~mm} \\
(\%)\end{array}$} & \multirow{2}{*}{$\begin{array}{c}2-63 \mu \mathrm{m} \\
(\%)\end{array}$} & \multirow{2}{*}{$\begin{array}{c}<2 \mu \mathrm{m} \\
(\%)\end{array}$} \\
\hline & & $(n)$ & $(\%)$ & & & \\
\hline \multicolumn{7}{|l|}{ 119-746A- } \\
\hline $4 \mathrm{H}-1,48-50$ & 165.26 & 0 & 0.0 & 0.7 & 22.3 & 77.0 \\
\hline $4 \mathrm{H}-2,48-50$ & 166.70 & 0 & 0.0 & 0.3 & 22.3 & 77.4 \\
\hline $4 \mathrm{H}-3,48-50$ & 168.15 & 0 & 0.0 & 1.1 & 16.1 & 82.8 \\
\hline $4 \mathrm{H}-4,48-50$ & 169.59 & 0 & 0.0 & 0.0 & 16.9 & 83.1 \\
\hline $4 \mathrm{H}-5,48-50$ & 171.03 & 0 & 0.0 & 0.3 & 36.3 & 63.4 \\
\hline $4 \mathrm{H}-6,48-50$ & 172.47 & 1 & 0.4 & 0.7 & 44.5 & 54.4 \\
\hline $4 \mathrm{H}-7,48-50$ & 173.92 & 0 & 0.0 & 0.5 & 7.7 & 91.8 \\
\hline $5 \mathrm{H}-1,48-50$ & 174.75 & 0 & 0.0 & 5.4 & 27.5 & 67.1 \\
\hline $5 \mathrm{H}-2,48-50$ & 176.18 & 2 & 1.2 & 4.3 & 26.4 & 68.1 \\
\hline $5 \mathrm{H}-3,48-50$ & 177.60 & 0 & 0.0 & 0.0 & 38.0 & 62.0 \\
\hline $5 \mathrm{H}-4,48-50$ & 179.02 & 1 & 0.6 & 0.5 & 20.8 & 78.1 \\
\hline $5 \mathrm{H}-5,48-50$ & 180.44 & 1 & 0.4 & 2.3 & 25.9 & 71.4 \\
\hline $5 \mathrm{H}-6,48-50$ & 181.86 & 0 & 0.0 & 6.2 & 36.5 & 57.3 \\
\hline $5 \mathrm{H}-7,48-50$ & 183.28 & 0 & 0.0 & 2.0 & 29.0 & 69.0 \\
\hline $6 \mathrm{H}-1,48-50$ & 184.27 & 0 & 0.0 & 1.2 & 32.1 & 66.6 \\
\hline $6 \mathrm{H}-2,48-50$ & 185.74 & 0 & 0.0 & 0.8 & 38.1 & 61.1 \\
\hline $6 \mathrm{H}-3,48-50$ & 187.21 & 0 & 0.0 & 2.4 & 39.2 & 58.3 \\
\hline $6 \mathrm{H}-4,48-50$ & 188.68 & 0 & 0.0 & 0.1 & 33.2 & 66.7 \\
\hline $6 \mathrm{H}-5,48-50$ & 190.15 & 0 & 0.0 & 0.6 & 34.0 & 65.3 \\
\hline $6 \mathrm{H}-6,48-50$ & 191.62 & 0 & 0.0 & 0.0 & 32.5 & 67.5 \\
\hline $6 \mathrm{H}-7,5-7$ & 192.67 & 0 & 0.0 & 0.3 & 22.0 & 77.7 \\
\hline $7 \mathrm{H}-1,48-50$ & 193.77 & 0 & 0.0 & 0.0 & 35.0 & 65.0 \\
\hline $7 \mathrm{H}-2,48-50$ & 195.22 & 0 & 0.0 & 0.6 & 25.0 & 74.5 \\
\hline $7 \mathrm{H}-3,48-50$ & 196.68 & 0 & 0.0 & 0.0 & 41.6 & 58.4 \\
\hline $7 \mathrm{H}-4,48-50$ & 198.13 & 0 & 0.0 & 0.0 & 32.1 & 67.9 \\
\hline $7 \mathrm{H}-5,48-50$ & 199.59 & 0 & 0.0 & 0.4 & 19.4 & 80.2 \\
\hline $7 \mathrm{H}-6,48-50$ & 201.05 & 0 & 0.0 & 2.2 & 29.4 & 68.5 \\
\hline $7 \mathrm{H}-7,48-50$ & 202.50 & 1 & 1.1 & 0.5 & 17.2 & 81.2 \\
\hline $8 \mathrm{H}-1,48-50$ & 203.28 & 0 & 0.0 & 0.0 & 37.4 & 62.6 \\
\hline $8 \mathrm{H}-2,48-50$ & 204.78 & 0 & 0.0 & 0.5 & 42.2 & 57.2 \\
\hline $8 \mathrm{H}-3,48-50$ & 206.28 & 0 & 0.0 & 0.1 & 40.9 & 59.1 \\
\hline $8 \mathrm{H}-5,48-50$ & 207.93 & 0 & 0.0 & 0.3 & 33.5 & 66.1 \\
\hline $9 \mathrm{H}-4,42-44$ & 214.22 & 0 & 0.0 & 0.4 & 18.1 & 81.5 \\
\hline $9 \mathrm{H}-5,42-44$ & 215.72 & 0 & 0.0 & 0.0 & 34.3 & 65.7 \\
\hline $9 \mathrm{H}-6,42-44$ & 217.22 & 3 & 1.9 & 3.0 & 28.2 & 66.8 \\
\hline $10 \mathrm{H}-1,48-50$ & 218.26 & 0 & 0.0 & 0.0 & 26.2 & 73.8 \\
\hline $10 \mathrm{H}-2,48-50$ & 219.70 & 0 & 0.0 & 0.0 & 35.6 & 64.4 \\
\hline $10 \mathrm{H}-3,48-50$ & 221.15 & 0 & 0.0 & 0.0 & 13.2 & 86.8 \\
\hline $10 \mathrm{H}-4,48-50$ & 222.59 & 0 & 0.0 & 2.4 & 33.2 & 64.4 \\
\hline $10 \mathrm{H}-5,48-50$ & 224.03 & 0 & 0.0 & 0.4 & 14.1 & 85.5 \\
\hline $10 \mathrm{H}-6,48-50$ & 225.47 & 0 & 0.0 & 0.3 & 20.6 & 79.2 \\
\hline $11 X-1,48-50$ & 227.67 & 0 & 0.0 & 1.0 & 24.5 & 74.4 \\
\hline $11 X-2,48-50$ & 228.83 & 0 & 0.0 & 0.1 & 19.8 & 80.1 \\
\hline $11 X-3,48-50$ & 230.00 & 0 & 0.0 & 0.0 & 21.5 & 78.5 \\
\hline $11 X-4,48-50$ & 231.16 & 0 & 0.0 & 0.3 & 23.6 & 76.1 \\
\hline $11 X-5,48-50$ & 232.32 & 0 & 0.0 & 0.1 & 16.0 & 84.0 \\
\hline $11 X-6,48-50$ & 233.49 & 0 & 0.0 & 0.0 & 15.7 & 84.3 \\
\hline $13 X-1,48-50$ & 242.67 & 0 & 0.0 & 0.0 & 34.1 & 65.9 \\
\hline $13 \times-2,48-50$ & 244.14 & 0 & 0.0 & 0.2 & 28.7 & 71.1 \\
\hline $13 X-3,48-50$ & 245.61 & 0 & 0.0 & 0.0 & 8.6 & 91.4 \\
\hline $13 X-4,48-50$ & 247.08 & 0 & 0.0 & 0.1 & 37.9 & 62.0 \\
\hline $13 X-5,48-50$ & 248.55 & 0 & 0.0 & 0.0 & 11.8 & 88.2 \\
\hline $13 X-6,48-50$ & 250.02 & 0 & 0.0 & 0.0 & 29.2 & 70.8 \\
\hline $14 X-1,48-50$ & 252.28 & 0 & 0.0 & 0.0 & 47.1 & 52.9 \\
\hline $15 \mathrm{X}-1,48-50$ & 261.98 & 0 & 0.0 & 0.1 & 7.8 & 92.1 \\
\hline $16 \mathrm{X}-1,48-50$ & 271.58 & 0 & 0.0 & 0.0 & 12.8 & 87.2 \\
\hline
\end{tabular}

Appendix Table 5. Amount of terrigenous clay (nonbiogenic, $<2 \mu \mathrm{m}$ ) and relative percentages of the clay minerals smectite, illite, chlorite, and kaolinite at ODP Sites $\mathbf{7 4 5}$ and $\mathbf{7 4 6 .}$

\begin{tabular}{lllllll}
\hline $\begin{array}{l}\text { Core, section, } \\
\text { interval }(\mathrm{cm})\end{array}$ & $\begin{array}{c}\text { Depth } \\
(\mathrm{mbs})\end{array}$ & $\begin{array}{c}\text { Clay } \\
(\%)\end{array}$ & $\begin{array}{c}\text { Smectite } \\
(\%)\end{array}$ & $\begin{array}{c}\text { Illite } \\
(\%)\end{array}$ & $\begin{array}{c}\text { Chlorite } \\
(\%)\end{array}$ & $\begin{array}{c}\text { Kaolinite } \\
(\%)\end{array}$ \\
\hline
\end{tabular}

119-745B-

\begin{tabular}{|c|c|c|c|c|c|c|}
\hline $1 \mathrm{H}-1,48-50$ & 0.47 & 31.9 & 20 & 62 & 18 & 0 \\
\hline $1 \mathrm{H}-3,48-50$ & 3.41 & 44.2 & 12 & 72 & 9 & 8 \\
\hline $1 \mathrm{H}-4,20-22$ & 4.61 & 40.6 & 19 & 58 & 13 & 10 \\
\hline $2 \mathrm{H}-1,48-50$ & 5.47 & 27.3 & 45 & 34 & 21 & 1 \\
\hline $2 \mathrm{H}-2,48-50$ & 6.92 & 39.2 & 22 & 62 & 9 & 8 \\
\hline $2 \mathrm{H}-3,48-50$ & 8.38 & 33.8 & 41 & 45 & 11 & 3 \\
\hline $2 \mathrm{H}-4,48-50$ & 9.83 & 25.6 & 24 & 28 & 46 & 2 \\
\hline $2 \mathrm{H}-5,48-50$ & 11.29 & 29.2 & 26 & 62 & 11 & 1 \\
\hline $2 \mathrm{H}-6,48-50$ & 12.75 & 25.6 & 9 & 74 & 8 & 9 \\
\hline $2 \mathrm{H}-7,48-50$ & 14.20 & 40.1 & 21 & 60 & 7 & 13 \\
\hline $3 \mathrm{H}-1,48-50$ & 14.98 & 31.3 & 25 & 54 & 22 & 0 \\
\hline $3 \mathrm{H}-2,48-50$ & 16.48 & 28.1 & 26 & 51 & 22 & 1 \\
\hline $3 \mathrm{H}-3,48-50$ & 17.98 & 35.1 & 21 & 62 & 6 & 11 \\
\hline $3 \mathrm{H}-4,48-50$ & 19.48 & 36.6 & 24 & 62 & 2 & 12 \\
\hline $3 \mathrm{H}-5,48-50$ & 20.98 & 28.8 & 46 & 46 & 6 & 2 \\
\hline $3 \mathrm{H}-6,49-52$ & 22.49 & 32.8 & 16 & 69 & 6 & 9 \\
\hline $4 \mathrm{H}-1,50-52$ & 24.48 & 28.3 & 33 & 45 & 16 & 6 \\
\hline $4 \mathrm{H}-2,50-52$ & 25.94 & 37.6 & 23 & 62 & 6 & 9 \\
\hline $4 \mathrm{H}-3,50-52$ & 27.40 & 46.0 & 14 & 65 & 12 & 10 \\
\hline $4 \mathrm{H}-4,50-52$ & 28.85 & 32.7 & 37 & 51 & 11 & 1 \\
\hline $4 \mathrm{H}-5,50-52$ & 30.31 & 29.6 & 30 & 59 & 6 & 5 \\
\hline $4 \mathrm{H}-6,50-52$ & 31.77 & 30.1 & 20 & 57 & 15 & 8 \\
\hline $4 \mathrm{H}-7,50-52$ & 33.22 & 62.7 & 20 & 47 & 18 & 15 \\
\hline $5 \mathrm{H}-1,48-50$ & 33.97 & 39.0 & 37 & 46 & 6 & 10 \\
\hline $5 \mathrm{H}-2,48-50$ & 35.42 & 27.6 & 18 & 57 & 10 & 15 \\
\hline $5 \mathrm{H}-3,48-50$ & 36.88 & 38.3 & 16 & 62 & 11 & 10 \\
\hline $5 \mathrm{H}-4,48-50$ & 38.33 & 46.1 & 25 & 56 & 10 & 9 \\
\hline $5 \mathrm{H}-5,48-50$ & 39.79 & 50.4 & 11 & 59 & 18 & 12 \\
\hline $5 \mathrm{H}-6,48-50$ & 41.25 & 54.4 & 11 & 64 & 14 & 11 \\
\hline $5 \mathrm{H}-7,48-50$ & 42.70 & 40.1 & 16 & 59 & 20 & 5 \\
\hline $6 \mathrm{H}-1,48-50$ & 43.48 & 46.3 & 18 & 55 & 11 & 15 \\
\hline $6 \mathrm{H}-2,48-50$ & 44.98 & 46.3 & 16 & 65 & 11 & 8 \\
\hline $6 \mathrm{H}-3,48-50$ & 46.48 & 58.7 & 17 & 62 & 10 & 11 \\
\hline $6 \mathrm{H}-4,48-50$ & 47.98 & & 12 & 56 & 6 & 25 \\
\hline $6 \mathrm{H}-5,43-45$ & 49.43 & 28.5 & 19 & 62 & 11 & 8 \\
\hline $6 \mathrm{H}-6,48-50$ & 50.98 & 33.4 & 24 & 58 & 6 & 12 \\
\hline $7 \mathrm{H}-1,48-50$ & 52.97 & 28.6 & 28 & 44 & 25 & 2 \\
\hline $7 \mathrm{H}-2,48-50$ & 54.42 & 54.0 & 14 & 63 & 5 & 17 \\
\hline $7 \mathrm{H}-3,48-50$ & 55.88 & 65.9 & 21 & 54 & 17 & 8 \\
\hline $7 \mathrm{H}-4,48-50$ & 57.33 & 29.8 & 35 & 44 & 21 & 0 \\
\hline $7 \mathrm{H}-5,48-50$ & 58.79 & 41.9 & 20 & 56 & 13 & 10 \\
\hline $7 \mathrm{H}-6,48-50$ & 60.25 & 26.3 & 28 & 57 & 5 & 10 \\
\hline $7 \mathrm{H}-7,48-50$ & 61.70 & 31.8 & 10 & 67 & 14 & 9 \\
\hline $8 \mathrm{H}-1,48-50$ & 62.47 & 33.5 & 14 & 59 & 11 & 15 \\
\hline $8 \mathrm{H}-2,48-50$ & 63.92 & 57.3 & 8 & 49 & 18 & 24 \\
\hline $8 \mathrm{H}-3,48-50$ & 65.38 & 38.0 & 29 & 50 & 15 & 7 \\
\hline $8 \mathrm{H}-4,48-50$ & 66.83 & 22.5 & 36 & 46 & 15 & 3 \\
\hline $8 \mathrm{H}-5,48-50$ & 68.29 & 37.4 & 36 & 48 & 10 & 6 \\
\hline $8 \mathrm{H}-6,48-50$ & 69.75 & 53.4 & 14 & 68 & 15 & 3 \\
\hline $8 \mathrm{H}-7,48-50$ & 71.20 & 33.8 & 28 & 58 & 14 & 0 \\
\hline $9 \mathrm{H}-1,48-50$ & 71.95 & 21.1 & 34 & 49 & 9 & 8 \\
\hline $9 \mathrm{H}-2,48-50$ & 73.38 & 60.5 & 11 & 69 & 12 & 7 \\
\hline $9 \mathrm{H}-3,48-50$ & 74.80 & 14.6 & 19 & 61 & 17 & 2 \\
\hline $9 \mathrm{H}-4,48-50$ & 76.22 & 62.3 & 14 & 60 & 16 & 9 \\
\hline $9 \mathrm{H}-5,48-50$ & 77.64 & 24.3 & 25 & 61 & 10 & 3 \\
\hline $9 \mathrm{H}-6,48-50$ & 79.06 & 38.4 & 47 & 34 & 16 & 3 \\
\hline $9 \mathrm{H}-7,48-50$ & 80.48 & 27.9 & 24 & 61 & 5 & 10 \\
\hline $10 \mathrm{H}-1,48-50$ & 81.46 & 38.3 & 19 & 58 & 17 & 7 \\
\hline $10 \mathrm{H}-2,48-50$ & 82.90 & 39.0 & 23 & 60 & 13 & 5 \\
\hline $10 \mathrm{H}-3,48-50$ & 84.35 & 54.1 & 19 & 49 & 18 & 13 \\
\hline $10 \mathrm{H}-4,48-50$ & 85.79 & 49.5 & 23 & 45 & 26 & 6 \\
\hline $10 \mathrm{H}-5,48-50$ & 87.23 & 39.9 & 12 & 55 & 15 & 19 \\
\hline $10 \mathrm{H}-6,48-50$ & 88.67 & 49.5 & 18 & 62 & 10 & 10 \\
\hline $10 \mathrm{H}-7,48-50$ & 90.12 & 40.5 & 17 & 56 & 13 & 15 \\
\hline $11 \mathrm{H}-1,48-50$ & 90.97 & 45.4 & 14 & 66 & 12 & 8 \\
\hline $11 \mathrm{H}-2,48-50$ & 92.42 & 31.2 & 25 & 64 & 4 & 7 \\
\hline $11 \mathrm{H}-3,48-50$ & 93.88 & 12.6 & 29 & 52 & 15 & 4 \\
\hline $11 \mathrm{H}-4,48-50$ & 95.33 & 10.0 & 23 & 61 & 15 & 1 \\
\hline $11 \mathrm{H}-5,48-50$ & 96.79 & 47.3 & 5 & 61 & 15 & 19 \\
\hline $11 \mathrm{H}-6,48-50$ & 98.25 & 42.8 & 29 & 58 & 8 & 6 \\
\hline $12 \mathrm{H}-1,48-50$ & 100.45 & 69.8 & 24 & 37 & 27 & 12 \\
\hline $12 \mathrm{H}-2,48-50$ & 101.88 & 48.7 & 45 & 42 & 4 & 9 \\
\hline $12 \mathrm{H}-3,48-50$ & 103.30 & 43.2 & 30 & 47 & 19 & 3 \\
\hline $12 \mathrm{H}-4,48-50$ & 104.72 & 41.5 & 33 & 50 & 14 & 3 \\
\hline
\end{tabular}


Appendix Table 5 (continued).

\begin{tabular}{|c|c|c|c|c|c|c|}
\hline $\begin{array}{l}\text { Core, section, } \\
\text { interval }(\mathrm{cm})\end{array}$ & $\begin{array}{l}\text { Depth } \\
\text { (mbsf) }\end{array}$ & $\begin{array}{l}\text { Clay } \\
(\%)\end{array}$ & $\begin{array}{c}\text { Smectite } \\
(\%)\end{array}$ & $\begin{array}{l}\text { Illite } \\
(\%)\end{array}$ & $\begin{array}{c}\text { Chlorite } \\
(\%)\end{array}$ & $\begin{array}{c}\text { Kaolinite } \\
(\%)\end{array}$ \\
\hline \multicolumn{7}{|l|}{ 119-745B-(Cont.) } \\
\hline $12 \mathrm{H}-5,48-50$ & 106.14 & 40.1 & 29 & 41 & 30 & 0 \\
\hline $12 \mathrm{H}-6,48-50$ & 107.56 & 53.5 & 29 & 48 & 11 & 12 \\
\hline $12 \mathrm{H}-7,48-50$ & 108.98 & 56.2 & 19 & 50 & 10 & 21 \\
\hline $13 \mathrm{H}-1,48-50$ & 109.96 & 62.9 & 21 & 51 & 12 & 16 \\
\hline $13 \mathrm{H}-2,48-50$ & 111.39 & 35.9 & 41 & 48 & 7 & 3 \\
\hline $13 \mathrm{H}-3,48-50$ & 112.81 & 56.5 & 20 & 53 & 15 & 11 \\
\hline $13 \mathrm{H}-4,48-50$ & 114.24 & 61.8 & 1 & 68 & 13 & 18 \\
\hline $13 \mathrm{H}-5,48-50$ & 115.67 & 69.7 & 68 & 27 & 5 & 0 \\
\hline $13 \mathrm{H}-6,48-50$ & 117.10 & 63.2 & 23 & 49 & 16 & 12 \\
\hline $13 \mathrm{H}-7,48-50$ & 118.53 & 46.1 & 19 & 58 & 11 & 12 \\
\hline $14 \mathrm{H}-1,48-50$ & 119.46 & 56.5 & 21 & 51 & 13 & 15 \\
\hline $14 \mathrm{H}-2,48-50$ & 120.90 & 42.2 & 21 & 46 & 16 & 17 \\
\hline $14 \mathrm{H}-3,48-50$ & 122.35 & 61.6 & 14 & 53 & 21 & 13 \\
\hline $14 \mathrm{H}-4,48-50$ & 123.79 & 49.4 & 16 & 64 & 8 & 12 \\
\hline $14 \mathrm{H}-5,48-50$ & 125.23 & 52.5 & 18 & 58 & 8 & 16 \\
\hline $14 \mathrm{H}-6,48-50$ & 126.67 & 51.5 & 12 & 68 & 13 & 7 \\
\hline $14 \mathrm{H}-7,48-50$ & 128.12 & 63.7 & 14 & 71 & 6 & 9 \\
\hline $15 \mathrm{H}-1,48-50$ & 128.98 & 59.8 & 12 & 71 & 16 & 2 \\
\hline $15 \mathrm{H}-2,48-50$ & 130.48 & 61.3 & 15 & 73 & 8 & 3 \\
\hline $15 \mathrm{H}-3,48-50$ & 131.98 & 47.9 & 19 & 72 & 6 & 3 \\
\hline $15 \mathrm{H}-4,48-50$ & 133.48 & 46.6 & 24 & 69 & 4 & 3 \\
\hline $15 \mathrm{H}-5,48-50$ & 134.98 & 56.6 & 16 & 68 & 16 & 0 \\
\hline $15 \mathrm{H}-6,48-50$ & 136.48 & 40.4 & 24 & 65 & 12 & 0 \\
\hline $17 \mathrm{H}-1,48-50$ & 139.47 & 50.9 & 21 & 70 & 6 & 3 \\
\hline $17 \mathrm{H}-2,48-50$ & 140.94 & 31.8 & 18 & 69 & 12 & 1 \\
\hline $17 \mathrm{H}-3,48-50$ & 142.41 & 37.1 & 38 & 47 & 12 & 3 \\
\hline $17 \mathrm{H}-4,48-50$ & 143.88 & 41.7 & 18 & 72 & 4 & 7 \\
\hline $17 \mathrm{H}-5,48-50$ & 145.35 & 60.2 & 11 & 69 & 19 & 0 \\
\hline $17 \mathrm{H}-6,48-50$ & 146.82 & 43.7 & 13 & 73 & 9 & 5 \\
\hline $17 \mathrm{H}-7,46-48$ & 148.27 & 45.7 & 18 & 66 & 14 & 2 \\
\hline $18 \mathrm{H}-1,44-46$ & 148.92 & 53.1 & 11 & 79 & 5 & 6 \\
\hline $18 \mathrm{H}-2,44-46$ & 150.37 & 56.0 & 16 & 69 & 5 & 10 \\
\hline $18 \mathrm{H}-3,44-46$ & 151.81 & & & & & \\
\hline $18 \mathrm{H}-4,44-46$ & 153.25 & 40.9 & 17 & 62 & 14 & 7 \\
\hline $18 \mathrm{H}-5,44-46$ & 154.69 & 41.6 & 13 & 75 & 5 & 6 \\
\hline $18 \mathrm{H}-6,44-46$ & 156.13 & 58.5 & 21 & 71 & 3 & 6 \\
\hline $18 \mathrm{H}-7,44-46$ & 157.58 & 47.4 & 13 & 74 & 12 & 1 \\
\hline $19 \mathrm{H}-1,40-42$ & 158.38 & 37.1 & 18 & 67 & 9 & 5 \\
\hline $19 \mathrm{H}-2,40-42$ & 159.80 & 40.8 & 23 & 64 & 9 & 4 \\
\hline $19 \mathrm{H}-3,40-42$ & 161.23 & & & & & \\
\hline $19 \mathrm{H}-4,40-42$ & 162.69 & 44.7 & 21 & 72 & 3 & 3 \\
\hline $19 \mathrm{H}-5,40-42$ & 164.08 & 54.3 & 10 & 64 & 24 & 2 \\
\hline $19 \mathrm{H}-6,40-42$ & 165.50 & 55.0 & 9 & 85 & 6 & 0 \\
\hline $19 \mathrm{H}-7,40-42$ & 166.93 & 53.2 & 15 & 63 & 22 & 0 \\
\hline $20 \mathrm{H}-1,52-54$ & 168.00 & 31.4 & 28 & 60 & 10 & 3 \\
\hline $20 \mathrm{H}-2,47-49$ & 169.39 & 41.5 & 31 & 52 & 5 & 11 \\
\hline $20 \mathrm{H}-3,47-49$ & 170.84 & 59.5 & 19 & 58 & 12 & 12 \\
\hline $20 \mathrm{H}-4,47-49$ & 172.28 & 39.1 & 51 & 14 & 30 & 5 \\
\hline $20 \mathrm{H}-5,47-49$ & 173.72 & 56.9 & 24 & 56 & 4 & 16 \\
\hline $20 \mathrm{H}-6,47-49$ & 175.16 & 45.0 & 28 & 60 & 4 & 9 \\
\hline $20 \mathrm{H}-7,47-49$ & 176.61 & 63.1 & 11 & 63 & 11 & 16 \\
\hline $21 \mathrm{H}-2,48-50$ & 178.88 & 54.5 & 15 & 62 & 17 & 5 \\
\hline $21 \mathrm{H}-3,48-50$ & 180.30 & 53.8 & 13 & 60 & 16 & 11 \\
\hline $21 \mathrm{H}-4,48-50$ & 181.72 & 36.6 & 17 & 51 & 23 & 9 \\
\hline $21 \mathrm{H}-5,48-50$ & 183.14 & 48.3 & 30 & 60 & 3 & 7 \\
\hline $21 \mathrm{H}-6,48-50$ & 184.56 & 44.2 & 25 & 62 & 6 & 7 \\
\hline $21 \mathrm{H}-7,48-50$ & 185.98 & 45.9 & 17 & 63 & 9 & 11 \\
\hline $22 \mathrm{H}-1,48-50$ & 186.98 & 53.2 & 15 & 65 & 13 & 6 \\
\hline $22 \mathrm{H}-2,48-50$ & 188.48 & 48.1 & 10 & 75 & 8 & 7 \\
\hline $22 \mathrm{H}-3,48-50$ & 189.98 & 37.3 & 23 & 66 & 7 & 4 \\
\hline $22 \mathrm{H}-4,48-50$ & 191.48 & 43.0 & 21 & 62 & 14 & 3 \\
\hline $22 \mathrm{H}-5,48-50$ & 192.98 & 36.9 & 27 & 62 & 5 & 6 \\
\hline $22 \mathrm{H}-6,48-50$ & 194.48 & 55.8 & 17 & 61 & 15 & 7 \\
\hline $23 \mathrm{H}-1,48-50$ & 196.46 & 47.7 & 20 & 57 & 13 & 10 \\
\hline $23 \mathrm{H}-2,48-50$ & 197.89 & 52.2 & 15 & 65 & 15 & 6 \\
\hline $23 \mathrm{H}-3,48-50$ & 199.31 & 46.4 & 22 & 59 & 19 & 0 \\
\hline $23 \mathrm{H}-4,48-50$ & 200.74 & 39.1 & 25 & 57 & 9 & 9 \\
\hline $23 \mathrm{H}-5,48-50$ & 202.17 & 42.3 & 13 & 66 & 15 & 6 \\
\hline $23 \mathrm{H}-6,48-50$ & 203.60 & 33.5 & 34 & 46 & 14 & 5 \\
\hline $23 \mathrm{H}-7,48-50$ & 205.03 & 48.8 & 18 & 66 & 8 & 8 \\
\hline $24 \mathrm{H}-1,48-50$ & 205.95 & 41.7 & 5 & 72 & 23 & 0 \\
\hline $24 \mathrm{H}-2,48-50$ & 207.37 & 38.4 & 24 & 61 & 9 & 6 \\
\hline $24 \mathrm{H}-3,48-50$ & 208.79 & 58.6 & 21 & 67 & 9 & 3 \\
\hline $24 \mathrm{H}-4,48-50$ & 210.11 & 47.4 & 17 & 70 & 13 & 0 \\
\hline $24 \mathrm{H}-5,48-50$ & 211.62 & 36.4 & 5 & 44 & 31 & 20 \\
\hline $24 \mathrm{H}-6,48-50$ & 213.04 & 48.9 & 21 & 66 & 3 & 9 \\
\hline
\end{tabular}

Appendix Table 5 (continued).

\begin{tabular}{|c|c|c|c|c|c|c|}
\hline $\begin{array}{l}\text { Core, section, } \\
\text { interval }(\mathrm{cm})\end{array}$ & $\begin{array}{l}\text { Depth } \\
\text { (mbsf) }\end{array}$ & $\begin{array}{l}\text { Clay } \\
(\%)\end{array}$ & $\begin{array}{l}\text { Smectite } \\
(\%)\end{array}$ & $\begin{array}{l}\text { Illite } \\
(\%)\end{array}$ & $\begin{array}{c}\text { Chlorite } \\
(\%)\end{array}$ & $\begin{array}{c}\text { Kaolinite } \\
\text { (\%) }\end{array}$ \\
\hline \multicolumn{7}{|l|}{ 119-745B-(Cont.) } \\
\hline $24 \mathrm{H}-7,48-50$ & 214.45 & 40.8 & 34 & 58 & 4 & 4 \\
\hline \multicolumn{7}{|l|}{$119-746 \mathrm{~A}-$} \\
\hline $4 \mathrm{H}-1,48-50$ & 165.26 & 50.2 & 18 & 62 & 14 & 7 \\
\hline $4 \mathrm{H}-2,48-50$ & 166.70 & 44.4 & 28 & 60 & 9 & 4 \\
\hline $4 \mathrm{H}-3,48-50$ & 168.15 & 42.4 & 25 & 54 & 10 & 10 \\
\hline $4 \mathrm{H}-4,48-50$ & 169.59 & 54.9 & 20 & 58 & 14 & 7 \\
\hline $4 \mathrm{H}-5,48-50$ & 171.03 & 35.4 & 24 & 57 & 11 & 8 \\
\hline $4 \mathrm{H}-6,48-50$ & 172.47 & 36.4 & 29 & 50 & 12 & 8 \\
\hline $4 \mathrm{H}-7,48-50$ & 173.92 & 47.8 & 18 & 54 & 20 & 7 \\
\hline $5 \mathrm{H}-1,48-50$ & 174.75 & 45.6 & 16 & 67 & 17 & 0 \\
\hline $5 \mathrm{H}-2,48-50$ & 176.18 & 38.8 & 27 & 59 & 11 & 3 \\
\hline $5 \mathrm{H}-3,48-50$ & 177.60 & 31.5 & 24 & 64 & 8 & 5 \\
\hline $5 \mathrm{H}-4,48-50$ & 179.02 & 47.8 & 12 & 69 & 9 & 10 \\
\hline $5 \mathrm{H}-5,48-50$ & 180.44 & 45.2 & 14 & 61 & 22 & 3 \\
\hline $5 \mathrm{H}-6,48-50$ & 181.86 & 43.8 & 19 & 60 & 18 & 2 \\
\hline $5 \mathrm{H}-7,48-50$ & 183.28 & 42.1 & 19 & 65 & 16 & 0 \\
\hline $6 \mathrm{H}-1,48-50$ & 184.27 & 42.9 & 20 & 61 & 17 & 2 \\
\hline $6 \mathrm{H}-2,48-50$ & 185.74 & 38.5 & 15 & 68 & 10 & 7 \\
\hline $6 \mathrm{H}-3,48-50$ & 187.21 & 35.1 & 17 & 65 & 12 & 6 \\
\hline $6 \mathrm{H}-4,48-50$ & 188.68 & 48.9 & 25 & 56 & 11 & 9 \\
\hline $6 \mathrm{H}-5,48-50$ & 190.15 & 41.8 & 18 & 70 & 5 & 6 \\
\hline $6 \mathrm{H}-6,48-50$ & 191.62 & 40.3 & 21 & 58 & 13 & 8 \\
\hline $6 \mathrm{H}-7,5-7$ & 192.67 & 41.3 & 28 & 55 & 10 & 6 \\
\hline $7 \mathrm{H}-1,48-50$ & 193.77 & 36.0 & 27 & 54 & 9 & 10 \\
\hline $7 \mathrm{H}-2,48-50$ & 195.22 & 41.9 & 24 & 63 & 7 & 5 \\
\hline $7 \mathrm{H}-3,48-50$ & 196.68 & 34.8 & 23 & 58 & 11 & 8 \\
\hline $7 \mathrm{H}-4,48-50$ & 198.13 & 41.0 & 19 & 59 & 13 & 9 \\
\hline $7 \mathrm{H}-5,48-50$ & 199.59 & 37.5 & 11 & 72 & 9 & 8 \\
\hline $7 \mathrm{H}-6,48-50$ & 201.05 & 43.4 & 12 & 67 & 13 & 9 \\
\hline $7 \mathrm{H}-7,48-50$ & 202.50 & 49.3 & 11 & 70 & 20 & 0 \\
\hline $8 \mathrm{H}-1,48-50$ & 203.28 & 38.6 & 26 & 53 & 18 & 3 \\
\hline $8 \mathrm{H}-2,48-50$ & 204.78 & 33.8 & 24 & 52 & 20 & 4 \\
\hline $8 \mathrm{H}-3,48-50$ & 206.28 & 29.1 & 18 & 60 & 19 & 4 \\
\hline $8 \mathrm{H}-5,48-50$ & 207.93 & 32.0 & 20 & 58 & 17 & 4 \\
\hline $9 \mathrm{H}-4,42-44$ & 214.22 & 47.0 & 21 & 56 & 21 & 2 \\
\hline $9 \mathrm{H}-5,42-44$ & 215.72 & 36.4 & 10 & 65 & 17 & 8 \\
\hline $9 \mathrm{H}-6,42-44$ & 217.22 & 43.7 & 15 & 63 & 20 & 2 \\
\hline $10 \mathrm{H}-1,48-50$ & 218.26 & 39.9 & 16 & 67 & 17 & 1 \\
\hline $10 \mathrm{H}-2,48-50$ & 219.70 & 40.1 & 19 & 66 & 11 & 3 \\
\hline $10 \mathrm{H}-3,48-50$ & 221.15 & 56.7 & 6 & 78 & 13 & 3 \\
\hline $10 \mathrm{H}-4,48-50$ & 222.59 & 37.9 & 15 & 69 & 10 & 6 \\
\hline $10 \mathrm{H}-5,48-50$ & 224.03 & 45.9 & 9 & 71 & 14 & 7 \\
\hline $10 \mathrm{H}-6,48-50$ & 225.47 & 44.1 & 24 & 59 & 9 & 8 \\
\hline $11 X-1,48-50$ & 227.67 & 47.8 & 14 & 65 & 17 & 4 \\
\hline $11 \times-2,48-50$ & 228.83 & 48.4 & 26 & 51 & 19 & 4 \\
\hline $11 X-3,48-50$ & 230.00 & 46.3 & 11 & 72 & 18 & 0 \\
\hline $11 \times-4,48-50$ & 231.16 & 38.7 & 16 & 62 & 13 & 8 \\
\hline $11 X-5,48-50$ & 232.32 & 57.8 & 18 & 64 & 5 & 13 \\
\hline $11 X-6,48-50$ & 233.49 & 57.0 & 5 & 76 & 18 & 1 \\
\hline $13 X-1,48-50$ & 242.67 & 36.3 & 29 & 52 & 11 & 8 \\
\hline $13 X-2,48-50$ & 244.14 & 43.0 & 28 & 49 & 20 & 3 \\
\hline $13 X-3,48-50$ & 245.61 & 54.7 & 7 & 69 & 12 & 12 \\
\hline $13 X-4,48-50$ & 247.08 & 41.7 & 11 & 57 & 29 & 4 \\
\hline $13 X-5,48-50$ & 248.55 & 52.4 & 12 & 68 & 8 & 13 \\
\hline $13 X-6,48-50$ & 250.02 & 38.4 & 20 & 54 & 17 & 8 \\
\hline $14 X-1,48-50$ & 252.28 & 48.9 & 7 & 70 & 18 & 5 \\
\hline $15 X-1,48-50$ & 261.98 & 58.3 & 17 & 59 & 15 & 9 \\
\hline $16 \times-1,48-50$ & 271.58 & 55.3 & 12 & 78 & 5 & 5 \\
\hline
\end{tabular}

